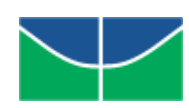

UNIVERSIDADE DE BRASÍLIA

FACULDADE DE ECONOMIA, ADMINISTRAÇÃO E CONTABILIDADE PROGRAMA DE PÓS-GRADUAÇÃO EM ADMINISTRAÇÃO

MESTRADO EM ADMINISTRAÇÃO

A RELAÇÃO ENTRE O SUPORTE À APRENDIZAGEM, AS CARACTERÍSTICAS INDIVIDUAIS DA CLIENTELA DE TD\&E E A MOTIVAÇÃO PARA O TREINAMENTO.

BRUNO ALEXANDRE BRAGA

Brasília, DF

2015 


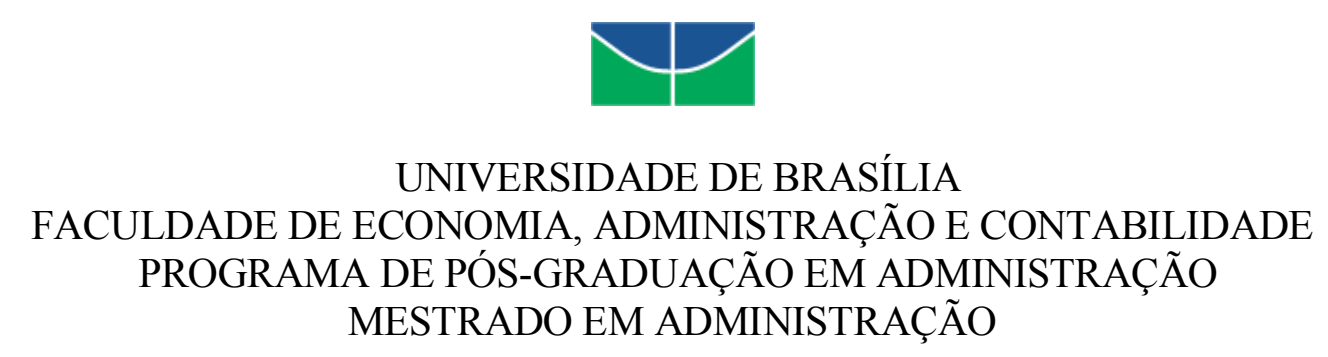

\section{A RELAÇÃO ENTRE O SUPORTE À APRENDIZAGEM, AS CARACTERÍSTICAS INDIVIDUAIS DA CLIENTELA DE TD\&E E A MOTIVAÇÃO PARA O TREINAMENTO.}

BRUNO ALEXANDRE BRAGA

Dissertação de Mestrado apresentada ao Programa de PósGraduação em administração, da Universidade de Brasília, como requisito parcial à obtenção do título de Mestre em Administração em Estudos Organizacionais e Gestão de Pessoas.

Orientador: Prof. Dr. Pedro P. M. Meneses 


\section{A RELAÇÃO ENTRE O SUPORTE À APRENDIZAGEM, AS CARACTERÍSTICAS INDIVIDUAIS DA CLIENTELA DE TD\&E E A MOTIVAÇÃO PARA O TREINAMENTO.}

Dissertação submetida ao Programa de Pós-Graduação em Administração como requisito parcial para obtenção do grau de mestre em Administração pela Universidade de Brasília. Aprovada em 25 de junho de 2015 pela banca examinadora constituída por:

Orientador: Prof. Dr. Pedro P. M. Meneses

Programa de Pós-Graduação em Administração

Universidade de Brasília - UnB

Membro Titular: Prof. Dr. Francisco Antônio Coelho Jr.

Programa de Pós-Graduação em Administração

Universidade de Brasília - UnB

Membro Titular: Prof. Dr. Jairo Eduardo Borges-Andrade

Programa de Pós-Graduação em Psicologia Social, do Trabalho e das Organizações

Universidade de Brasília - UnB

Membro Suplente: Prof. Dr. Antônio Isidro-Filho

Programa de Pós-Graduação em Administração

Universidade de Brasília - UnB 
Dedico esse trabalho a Deus, que ensina:

Ainda que eu tenha o dom de profecia e saiba todos os mistérios e todo o conhecimento, e tenha uma fé capaz de mover montanhas, mas não tiver amor, nada serei (1 Coríntios 13:1-2). 


\section{AGRADECIMENTOS}

Primeiramente a Deus, que é minha fonte de alegria, de esperança, fé e amor. Com Ele, foi possível acreditar que cada desafio poderia ser superado.

Aos meus familiares, por terem se esforçado para que eu conseguisse progredir nos estudos. E, de forma especial, à minha esposa, Priscilla, que me incentivou e me deu o suporte necessário para que eu pudesse ter sucesso em todas as fases do mestrado.

Ao Prof. Pedro Meneses, que aceitou me orientar e que foi sensível ao responder a várias dúvidas minhas a respeito da carreira de professor. Hoje, sou professor colaborador da UnB e professor executivo da pós-graduação da FGV. Quando eu entrei no mestrado, essas metas ainda não haviam sido alcançadas, mas hoje são realidades.

Ao Prof. Jairo que juntamente com o Prof. Pedro e à Prof. ${ }^{a}$ Gardênia foram os pioneiros em despertar meu interesse pela área de TD\&E.

Ao Prof. Francisco, pela disposição em analisar meu trabalho e por me ter mostrado a importância do suporte à aprendizagem dentro das organizações. Os conhecimentos que aprendi sobre suporte à aprendizagem acrescentaram também à minha atuação como gestor e professor.

Aos nobres professores que me ajudaram em algum momento da minha dissertação: Prof. ${ }^{\text {a }}$ Elaine Rabelo Neiva, Prof. ${ }^{a}$ Gisela Demo, Prof. Isaac Matias, Prof. Filipe Pereira e Prof. Luiz.

Aos meus superiores hierárquicos no INCRA, pelo suporte oferecido para a realização desta pesquisa.

Aos profissionais da área administrativa da Unb que fizeram o possível para me oferecer o apoio necessário, como por exemplo a Sonária e a Selma.

Aos meus colegas de mestrado, pelas trocas de informações e pelo incentivo às minhas metas acadêmicas e profissionais. 


\section{RESUMO}

O estudo da motivação para o treinamento é fundamental para a efetividade do treinamento no trabalho. Nesse sentido, é importante o desenvolvimento da linha de pesquisa que trata de propor e testar modelos compreensivos sobre como as características individuais e situacionais influenciam a motivação para o treinamento. A análise desse construto pode fornecer subsídios para o aperfeiçoamento dos modelos de avaliação da efetividade dos treinamentos. O presente trabalho objetivou adaptar e verificar evidências de validade da medida de suporte à aprendizagem e propor a testagem de um modelo que investiga o relacionamento das variáveis individuais (sexo, faixa etária e cargo de direção) e do suporte à aprendizagem com a motivação para o treinamento. O questionário de pesquisa utilizado fez a coleta de dados por meio das escalas de suporte à aprendizagem e valor instrumental do treinamento, do fator expectância e de questões sobre variáveis demográficas e profissionais. Essa coleta foi realizada via web. Participaram do estudo 155 servidores públicos federais de nível médio e superior, lotados em Brasília, nas unidades do INCRA-Sede. A escala de suporte à aprendizagem apresentou evidências de validade estatística e os índices psicométricos encontrados foram satisfatórios. Os resultados apontaram para a corroboração de apenas uma das hipóteses do modelo de pesquisa. Os indivíduos que possuíam percepção mais favorável de suporte à aprendizagem foram os que apresentaram maior força motivacional. As contribuições, limitações e agenda de pesquisa são apresentadas com base nos achados empíricos.

Palavras-chave: motivação para o treinamento, força motivacional, suporte à aprendizagem, valor instrumental do treinamento, efetividade do treinamento no trabalho. 


\begin{abstract}
The study of training motivation is critical to training effectiveness at work. Therefore, it is important to develop the area of research that propose and test comprehensive models of how individual and situational characteristics influence the training motivation. The analysis of this construct can provide subsidies for the improvement of models for assessing training effectiveness. This study aimed to adapt and verify evidence of statistical validity of learning support instrument and propose testing a model that investigates the relationship between the variables sex, age group, position of management, learning support and training motivation. The research questionnaire used collected data about the learning support and training instrumental value scales, the expectancy factor and demographic and professional variables. Data collection was conducted via web. The study included 155 individuals working for the federal government in Brasília, in units of INCRA-Sede, that had at least secondary education. The learning support instrument showed evidence of statistical validity and were found adequate psychometric indexes. The results showed corroboration for only one of the model's assumptions. Individuals who had more favorable perception of learning support showed the greatest motivational force. Contributions, limitations and research agenda are presented based on empirical findings.
\end{abstract}

Keywords: training motivation, motivating force, learning support, training instrumental value, training effectiveness at work. 


\section{SUMÁRIO}

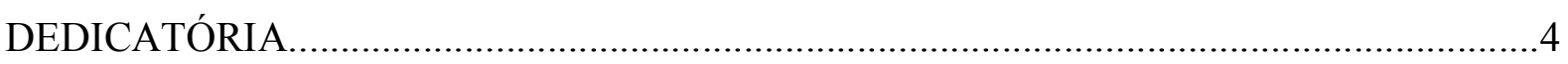

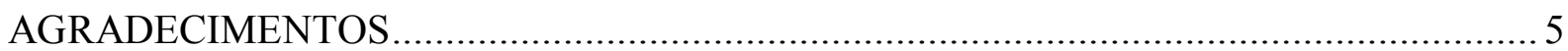

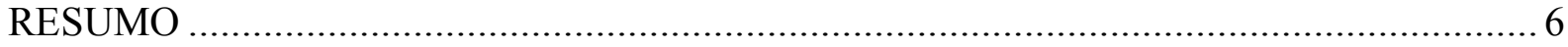

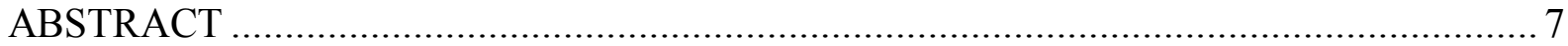

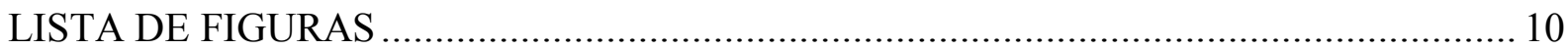

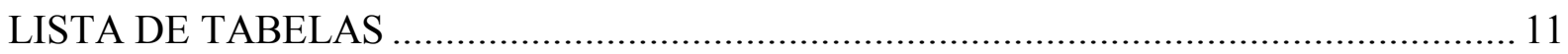

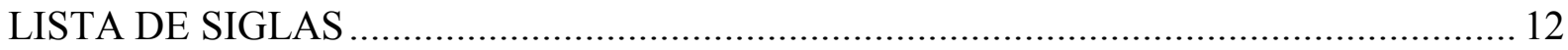

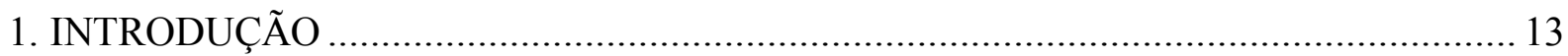

1.1 Pergunta de Pesquisa e Objetivo do Estudo ............................................................. 14

1.2 Justificativa e Relevância............................................................................................. 18

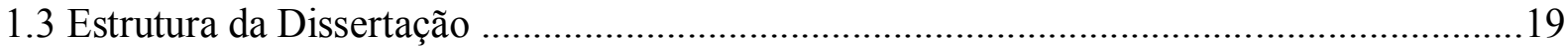

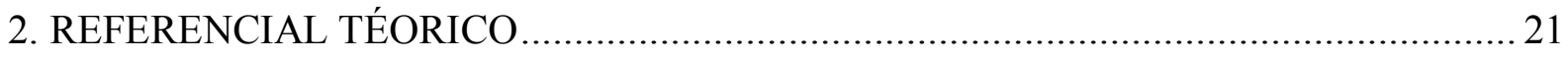

2.1 Modelos de Avaliação de Efetividade de TD\&E............................................................. 22

2.2 Motivação para o Treinamento: Conceitos e Medidas desse Construto ........................... 31

2.3 Revisão da Literatura Nacional sobre Motivação para o Treinamento ............................. 36

2.3.1 Dimensões e Categorias de Enquadramento Empregadas no Estudo ........................... 36

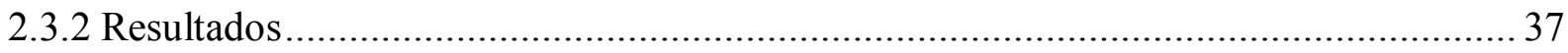

2.3.2.1 Identificação e Demografia da Produção Nacional sobre Motivação para o

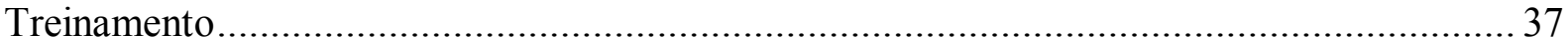

2.3.2.2 Finalidade da Produção Nacional sobre Motivação para o Treinamento ..................... 39

2.3.2.3 Tipificação Metodológica da Produção Nacional sobre Motivação para o Treinamento

2.3.2.4 Problemas de Investigação e Lacunas Identificadas nas Pesquisas .......................... 40

2.4 Variáveis Preditoras da Motivação para o Treinamento. .................................................. 43

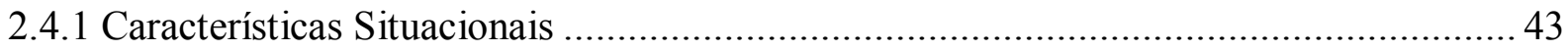

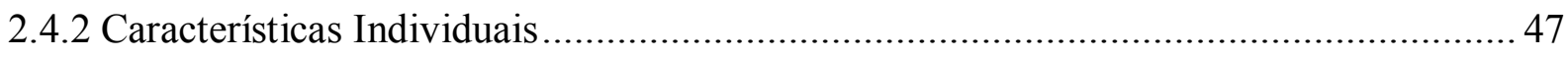

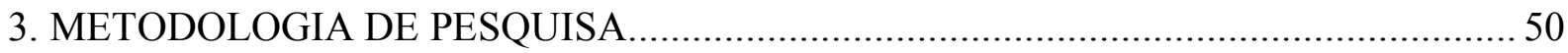




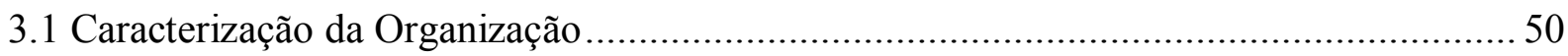

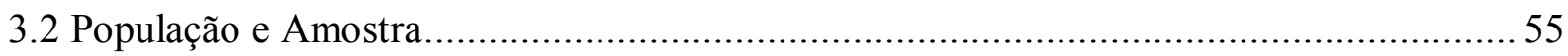

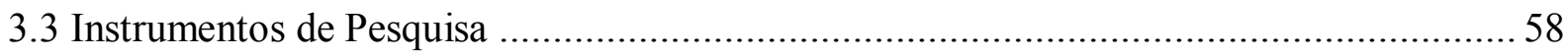

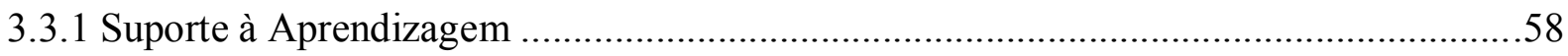

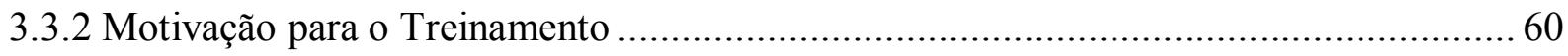

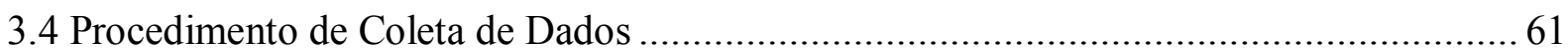

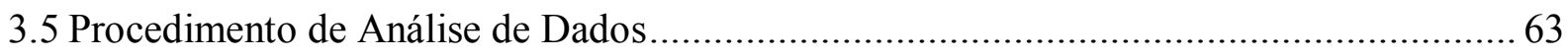

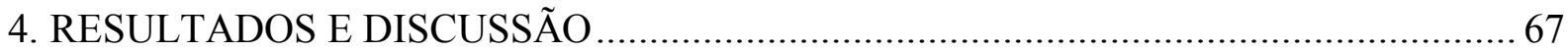

4.1 Fase 1: Validação Estatística da Escala de Suporte à Aprendizagem ............................. 67

4.2 Fase 2: Mensuração das Variáveis Utilizadas e Testagem do Modelo de Investigação ... 72

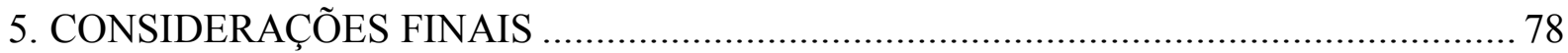

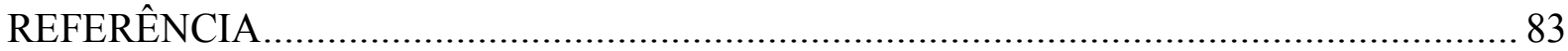

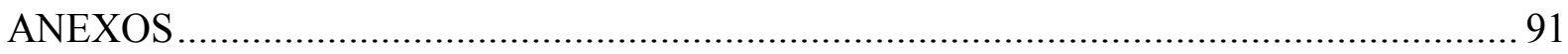

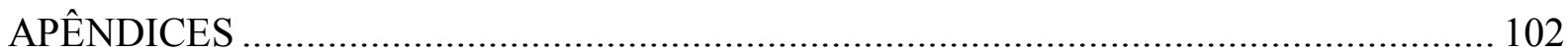




\section{LISTA DE FIGURAS}

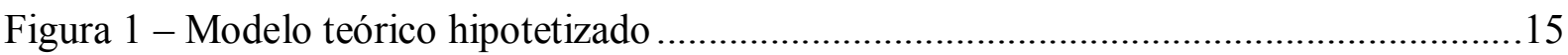

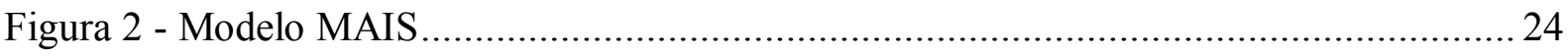

Figura 3 - Uso técnico em dicionários de psicologia do termo motivação ........................... 31

Figura 4 - Scree plot da matriz de dados da Escala de Suporte à Aprendizagem .................. 68 


\section{LISTA DE TABELAS}

Tabela 1 - Identificação e Demografia ....................................................................... 38

Tabela 2 - Periódicos e Quantitativo de Publicações............................................................ 38

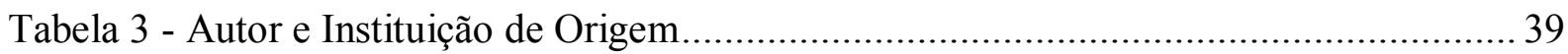

Tabela 4 - Finalidade Temática e Natureza das Investigações............................................ 39

Tabela 5 - Tipificação Metodológica das Investigações .................................................. 40

Tabela 6 - Oportunidades de Capacitação por Tipo de Ação.............................................. 54

Tabela 7 - Oportunidades de Capacitação por Modalidade ............................................... 54

Tabela 8 - Oportunidades de Capacitação por Tipo de Instituição ........................................ 55

Tabela 9 - Perfil da Amostra para a Análise de Fatores e Testagem do Modelo Empírico da

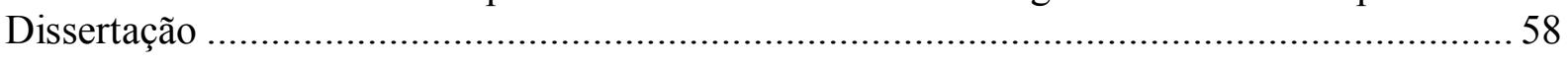

Tabela 10 - Índices Psicométricos da Escala de Suporte à Aprendizagem........................... 59

Tabela 11 - Índices Psicométricos da Escala de Valor Instrumental do Treinamento ............ 61

Tabela 12 - Resultados da Análise dos Componentes Principais para Cálculo do Número de

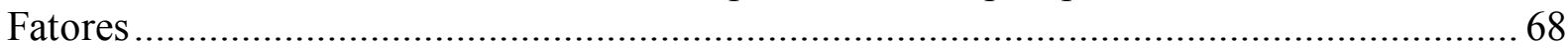

Tabela 13 - Eigenvalues Empíricos e Aleatórios dos Componentes da Amostras .................. 69

Tabela 14 - Itens, Carga Fatorial, H2, Média e Desvio Padrão do Fator Suporte à

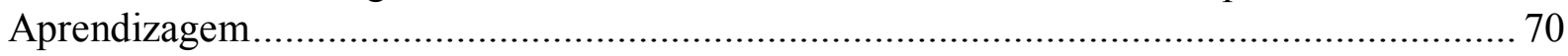

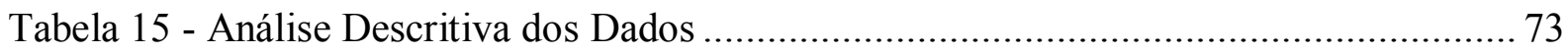

Tabela 16 - Resultado das Análises de Regressão Múltipla Stepwise .................................. 74 


\section{LISTA DE SIGLAS}

CGGP Coordenação Geral de Gestão de Pessoas

CHA

Conhecimentos, Habilidades e Atitudes

DA

Diretoria de Gestão Administrativa

GECC

Gratificação por Encargos de Curso ou Concurso

IMPACT

Modelo Integrado de Avaliação do Impacto do Treinamento no Trabalho

INCRA

Instituto Nacional de Colonização e Reforma Agrária

MAIS

Modelo de Avaliação Integrado e Somativo

PAA

Programa de Aquisição de Alimentos

PePSIC

Periódicos Eletrônicos de Psicologia

PJ

Pessoa Jurídica

RAC

Revista de Administração Contemporânea

$\mathrm{RH}$

Recursos Humanos

Scielo

Scientific Electronic Library Online

SIAPE

Sistema Integrado de Administração de Recursos Humanos

TD\&E

VD

Treinamento, Desenvolvimento e Educação

VI

Variável Dependente

Variável Independente 


\section{INTRODUÇÃO}

O estudo da motivação para o treinamento é fundamental para o sucesso das ações e programas de Treinamento, Desenvolvimento e Educação (TD\&E). A análise desse construto pode fornecer subsídios para o aperfeiçoamento dos modelos de avaliação da efetividade dos treinamentos (PATRICK; SMY; TOMBS; SHELTON, 2011; MATHIEU; MARTINEAU, 1997). Diante disso, essa dissertação se propôs investigar as relações entre variáveis individuais, o suporte à aprendizagem e a motivação para o treinamento, variável critério desse estudo.

De forma geral, os modelos clássicos de avaliação de efetividade de TD\&E, como, por exemplo, aqueles propostos por Kirkpatrick (1976) e Hamblin (1978), possuem como enfoque a reunião de juízos de valor sobre efeitos de curto (reação e aprendizagem) e longo prazo (comportamento no cargo, organização e valor final), sem explicar as razões dos resultados obtidos (BORGES-ANDRADE; ABBAD; MOURÃO, 2012). Diante disso, há estudos que criticam os modelos clássicos e argumentam sobre uma necessária ampliação da visão de efetividade de TD\&E, sugerindo que as variáveis individuais e contextuais, por exemplo, também sejam consideradas para o melhor entendimento do sucesso ou fracasso dos treinamentos (MATHIEU; MARTINEAU, 1997; TANENBAUM; YUKL, 1992).

Nesse cenário, outros modelos, agora também concentrados em variáveis até então desconsideradas pelos modelos clássicos, emergem na literatura sobre efetividade de treinamentos (MENESES; ZERBINI; ABBAD, 2010). O Modelo de Avaliação Integrado e Somativo (MAIS), proposto por Borges-Andrade $(1982,2006)$ é um exemplo de modelos mais completos, que trata tanto dos resultados dos eventos de TD\&E, quanto de variáveis relativas a insumos, procedimentos, processos e do ambiente sobre o qual os eventos ou programas de TD\&E ocorrem. As variáveis motivacionais estão inseridas dentro do componente insumos (BORGES-ANDRADE; ABBAD; MOURÃO, 2012) e influenciam os treinandos em suas habilidades de aquisição, retenção e vontade de aplicar os novos conhecimentos, habilidades e atitudes no trabalho (NGUYEN; KIM, 2013; MENESES; ABBAD; ZERBINI; LACERDA, 2006).

Todavia, apesar da literatura em geral ser clara sobre a influência da motivação para o treinamento nos resultados de aprendizagem, um modelo adequado, que explique os antecedentes da motivação para o treinamento, ainda não foi construído (NGUYEN; KIM, 2013). Nesse sentido, justificam-se as iniciativas de pesquisas que visem à construção de modelos explicativos das relações entre as variáveis individuais, situacionais e motivacionais. 


\subsection{Pergunta de Pesquisa e Objetivo do Estudo}

A literatura de TD\&E aponta a importância das variáveis motivacionais em relação à efetividade das ações de treinamento nas organizações (TANENBAUM; YUKL, 1992; MATHIEU; MARTINEAU, 1997; ABBAD, 1999; COLQUITT; LEPINE; NOE, 2000; BORGES-ANDRADE, 2006; PATRICK et al., 2011; BORGES-ANDRADE; ABBAD; MOURÃO, 2012; NGUYEN; KIM, 2013). Diante disso, os estudos que ajudam na compreensão da motivação para o treinamento são fundamentais para o aperfeiçoamento dos modelos de avaliação de efetividade dos treinamentos (MATHIEU; MARTINEAU, 1997).

De forma geral, duas linhas de pesquisas têm predominado sobre o tema da motivação para o treinamento: a) a especificação dos preditores da motivação para o treinamento e análise de suas relações com a aprendizagem; e b) a criação e testagem de modelos sobre como as características individuais e situacionais influenciam a motivação para o treinamento e os resultados de aprendizagem (COLQUITT, LE PINE E NOE, 2000)

Em relação à linha de pesquisa que trata sobre a criação e testagem de modelos sobre como as características individuais e situacionais influenciam a motivação para o treinamento e os resultados de aprendizagem, na qual o presente estudo de insere, há resultados de pesquisas que apontam, por exemplo, que treinandos que recebem mais suporte dos supervisores possuem maior motivação para o treinamento (CHIABURU; TEKLEAB, 2005) e que indivíduos do sexo feminino apresentam maior motivação para o treinamento que indivíduos do sexo masculino (THARENOU, 2001). Todavia, outros autores constataram que os estudos de variáveis situacionais em relação à motivação para o treinamento ainda são escassos (NGUYEN; KIM, 2013).

Além disso, na revisão efetuada para a realização desse estudo foi identificado que a literatura nacional apresenta escassez de pesquisas sobre a motivação para o treinamento. Apenas o estudo de Mourão e Marins (2010) tratou da linha de pesquisa sobre variáveis preditoras de motivação para o treinamento, conforme apresentado na Seção 2.3 da presente dissertação. Assim, justifica-se ainda a produção de novos estudos sobre a avaliação da relação entre as características individuais, situacionais e a motivação para o treinamento.

Dessa forma, esse estudo visa principalmente contribuir com o avanço das pesquisas sobre motivação para o treinamento, à medida que busca verificar se existe relação entre 
variáveis demográficas e profissionais, suporte à aprendizagem e motivação para o treinamento. Essa tarefa, em algumas situações, poderá exigir a construção (ou adaptação) e validação de instrumentos de pesquisa sobre variáveis de contexto, considerando que na literatura da área de TD\&E foram identificados relatos de pesquisas que apontam a escassez de instrumentos de medida de suporte. Borges-Andrade, Zerbini, Abbad e Mourão (2013), em sua revisão de literatura, identificaram a necessidade de construção e validação de novos instrumentos de avaliação de suporte $\square$ transferênà a que sej a mes peáfi cos e ali nhados co m as características dos programas de TD\&E estudados. Abbad e Sallorenzo (2001), também haviam apontado, em revisão desenvolvida há mais de uma década, que apesar de sua importância, ainda é pequeno o número de instrumentos de medida de suporte encontrados na literatura.

Assim, o presente trabalho tem como objetivo geral testar um modelo que investiga o relacionamento entre as variáveis suporte à aprendizagem, sexo, faixa etária, cargo de direção e a motivação para o treinamento no âmbito do Instituto Nacional de Colonização e Reforma Agrária (INCRA). A seguir, são apresentados os objetivos específicos dessa pesquisa:

i. Adaptar e verificar evidências de validade estatística do instrumento de medida de suporte à aprendizagem elaborado por Coelho Jr. (2009);

ii. Identificar o suporte à aprendizagem;

iii. Mensurar a motivação para o treinamento;

iv. Testar a relação entre as variáveis suporte à aprendizagem, sexo, faixa etária, cargo de direção e a motivação para o treinamento.

O modelo de investigação da presente dissertação foi elaborado para a testagem das relações entre as variáveis antecedentes e critério investigadas. A Figura 1 apresenta os componentes desse do modelo.

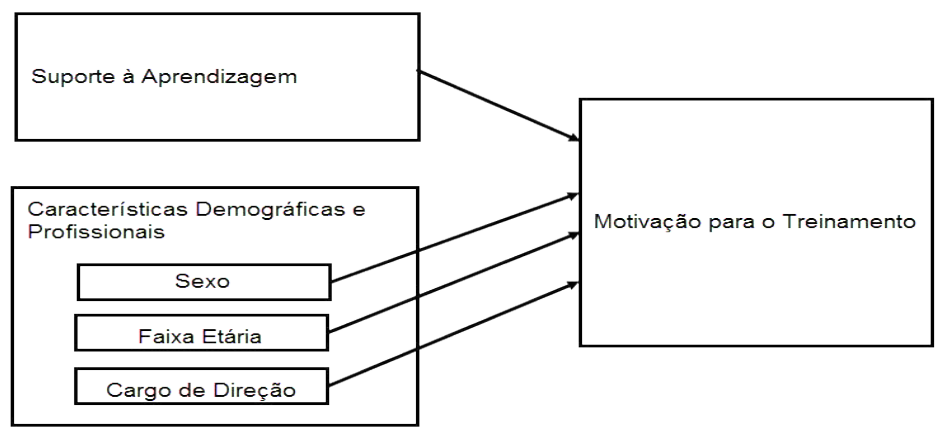

Figura 1 - Modelo teórico hipotetizado 
As hipóteses delineadas sobre a relação entre as variáveis suporte à aprendizagem, sexo, faixa etária, cargo de direção e a motivação para o treinamento são apresentadas a seguir.

A primeira hipótese refere-se ao teste de relação entre a variável suporte à aprendizagem e à variável critério motivação para o treinamento. A testagem da variável suporte à aprendizagem em relação à motivação para o treinamento é de cunho exploratório, não foi encontrada na literatura revisada testagem desse tipo de relacionamento na área de TD\&E. Todavia, em relação a construtos semelhantes, a literatura relata que treinandos que recebem mais suporte dos supervisores possuem maior motivação para o treinamento (CHIABURU; TEKLEAB, 2005). Assim, foi elaborada a seguinte hipótese para esse trabalho:

H1 Indivíduos que possuem percepção mais favorável do suporte à aprendizagem apresentarão maior motivação para o treinamento em relação àqueles que possuem percepção menos favorável do suporte à aprendizagem.

A segunda hipótese está relacionada à testagem da relação da motivação para o treinamento com à variável demográfica sexo. A literatura aponta que indivíduos do sexo feminino apresentam maior motivação para o treinamento que indivíduos do sexo masculino (THARENOU, 2001), assim foi formulada a seguinte hipótese.

H2 Indivíduos do sexo feminino apresentarão maior motivação para o treinamento em relação aos indivíduos do sexo masculino.

A terceira hipótese trata do teste da relação da variável faixa etária com a variável motivação para o treinamento. Em sua revisão sobre a motivação para o treinamento Colquitt, Lepine e Noe (2000) identificaram que além da variável gênero, outra variável demográfica que frequentemente aparece em pesquisas sobre treinamentos é a idade. Segundo Ebner, Freund, e Baltes (2006) seus resultados de pesquisa estão em consonância com relatos empíricos anteriores sobre diferenças relacionadas à idade e a motivação do indivíduo, por terem identificado que adultos da faixa etária mais jovem relataram motivação para a aprendizagem superior a demonstrada por adultos de maior faixa etária. Assim, a justificativa para esta investigação se pauta na ideia de se ampliarem as pesquisas na área e dessa forma, postula-se a seguinte hipótese: 
H3 Indivíduos de menor faixa etária apresentarão maior motivação para o treinamento em relação a indivíduos de faixa etária superior.

Ainda segundo a literatura revisada, o estudo de Ribeiro (2005) reportou ter encontrado relações significativas entre a variável cargo de direção e as variáveis valência e instrumentalidade. Para essa autora, indivíduos que ocupam cargo de direção tendem a dar menor importância ou a valorizar menos os resultados relacionados à carreira e os relacionamentos interpessoais no trabalho, e, além disso, percebem pouca utilidade de novas aprendizagens durante suas atividades de trabalho para a obtenção de resultados valorizados, quando comparados a indivíduos que não ocupam cargo de direção. O fato da maior parte dos ocupantes de cargos de direção já terem alcançado muitos dos resultados profissionais almejados, como altos salários e ascensão de carreira, pode ter contribuído para essa relação encontrada entre cargo de direção e valência. Essa autora argumenta também que o contexto de trabalho a que os participantes da pesquisa estão expostos pode ter influenciado o relacionamento encontrado entre cargo de direção e instrumentalidade. Contudo, seu estudo focou apenas no contexto de aprendizagem informal e as equações resultantes das análises de regressão que foram produzidas indicaram que a variância explicada pela variável cargo de direção foi baixa tanto em relação à valência, quanto em relação à instrumentalidade e que não foi encontrada relação preditiva entre cargo de direção e a variável expectância. Diante disso, foi formulada a terceira hipótese, que trata do estudo da predição da variável cargo de direção em relação à motivação para o treinamento, nesse estudo, focando em contexto de aprendizagem formal:

H4 Os servidores que não ocupam cargo de direção apresentarão maior motivação para o treinamento em relação aos ocupantes de cargo de direção.

Quanto à classificação e a definição de cada uma das variáveis integrantes do modelo de investigação apresentado, têm-se as seguintes definições:

- Motivação para o treinamento: variável critério do estudo, definida como a crença do indivíduo de que as habilidades adquiridas em treinamento serão úteis para alcançar recompensas de várias naturezas, levando-se em conta a importância atribuída pelo indivíduo a cada recompensa e sua expectativa de poder atingir as recompensas desejadas por meio dos treinamentos. Em pesquisas anteriores, essa variável geralmente é denominada de força motivacional, quando operacionalizada por 
meio do produto de três fatores (valência, instrumentalidade e expectância), e quando se deseja fazer sua avaliação parcial, por meio do produto dos fatores valência e instrumentalidade, a motivação para o treinamento geralmente é intitulada de valor instrumental do treinamento (ABBAD; LACERDA; PILATI, 2012; LACERDA, 2002). As demais Seções desse estudo seguem essas definições operacionais.

- Suporte à Aprendizagem: variável antecedente, que diz respeito à percepção do respondente sobre o apoio oferecido por pares e chefias ao trabalhador que busca aprender e aplicar novas habilidades em suas rotinas de trabalho (ABBAD; LACERDA; PILATI, 2012; COELHO JR.; ABBAD; TODESCHINI, 2005). A percepção individual será obtida por meio da medida de Coelho Jr. (2009), a ser revalidada na presente dissertação.

- Características demográficas e profissionais: variáveis antecedentes relacionadas ao sexo (feminino ou masculino), faixa etária (até 30 anos ou superior a 30 anos) e cargo de direção (ocupa cargo de direção ou não ocupa cargo de direção), incorporadas ao modelo de investigação tendo por base constatações de pesquisas anteriores (COLQUITT; LEPINE; NOE, 2000; EBNER; FREUND; BALTES, 2006; THARENOU, 2001; CHIABURU; TEKLEAB, 2005; RIBEIRO, 2005; ABBAD et al., 2006).

\subsection{Justificativa e Relevância}

O treinamento tem sido e continuará sendo uma valiosa ferramenta para gerenciar muitos desafios atuais e futuros das organizações (TRACEY; HINKIN; TANNENBAUM; MATHIEU, 2001). De forma geral, as organizações investem em treinamento por acreditarem que uma força de trabalho qualificada representa uma vantagem competitiva (SALAS; TANNENBAUM; KRAIGER; SMITH-JENTSCH, 2012). Contudo, pesquisas realizadas relatam que as organizações estão questionando a efetividade dos treinamentos realizados para preencher as lacunas de competências dos treinandos (AZIZ; AHMAD, 2011; LACERDA; ABBAD, 2003).

Em relação à efetividade dos treinamentos, para aumentar o retorno sobre $\mathrm{o}$ investimento em treinamento é crucial olhar para além das aulas dos eventos instrucionais, para entender como e porque o treinamento funciona ou não funciona (TRACEY et al., 2001). Nesse sentido, o melhor entendimento das variáveis individuais e situacionais é necessário 
para a compreensão do que deve ser feito para que os treinamentos desenvolvidos sejam efetivos (MATHIEU; MARTINEAU, 1997).

Assim, considerando que a motivação do treinando apresenta efeitos sobre a aquisição, retenção, e aplicação dos conhecimentos e habilidades adquiridos em treinamento (SILVA, 2010), a proposição de estudos que visem à construção de modelos que investiguem as variáveis relacionadas à motivação para o treinamento é fundamental para contribuir com o aperfeiçoamento dos modelos de avaliação de efetividade dos treinamentos (MATHIEU; MARTINEAU, 1997; TANENBAUM; YUKL, 1992; PATRICK et al., 2011).

Parte dos resultados de pesquisas de TD\&E sobre motivação para o treinamento vem sendo desenvolvida com base em achados sobre testagem de modelos sobre como as características individuais e situacionais influenciam a motivação para o treinamento (COLQUITT; LEPINE; NOE, 2000). No entanto, os resultados obtidos com a revisão da literatura nacional sobre motivação para o treinamento, produzida para a realização dessa dissertação, mostrou que apenas o estudo de Mourão e Marins (2010) tratou da linha de pesquisa sobre variáveis preditoras de motivação para o treinamento, o que mostra que em âmbito nacional, as pesquisas sobre essa temática precisam de maior atenção.

De forma geral, esta dissertação objetiva dar sua contribuição ao INCRA ao procurar produzir subsídios para que determinadas ações organizacionais possam ser tomadas pelos gestores da área de TD\&E visando ao aperfeiçoamento de futuros eventos instrucionais promovidos pela Autarquia, considerando que o melhor entendimento das variáveis individuais e situacionais colabora para o alcance da efetividade dos treinamentos. Conhecer o nível de motivação dos treinandos, por exemplo, é necessário devido a importância da motivação para os resultados dos treinamentos, tanto em termos de aprendizagem, quanto de transferência (ZAMBONI et al. 2011). Já a sua principal contribuição teórica, refere-se à realização do estudo sobre a testagem da relação entre às características individuais da clientela de TD\&E, o suporte à aprendizagem e à motivação para o treinamento, necessário em razão das recomendações da literatura internacional e da escassez dos estudos nacionais nessa área.

\subsection{Estrutura da Dissertação}

Essa dissertação está organizada em cinco Capítulos, sendo o primeiro esta Introdução, que contextualiza o estudo e apresenta a pergunta de pesquisa, o objetivo do estudo, sua 
justificativa e estrutura. O segundo trata do Referencial Teórico, que embasa esta pesquisa, e que apresenta: a estruturação do Capítulo; a importância dos modelos de efetividade de TD\&E; as principais conceituações, medidas e a importância da motivação para o treinamento, e a revisão nacional efetuada sobre a motivação para o treinamento, o objeto principal deste estudo. O terceiro apresenta os aspectos metodológicos propostos para a consecução dos objetivos almejados. O quarto faz a apresentação e discussão dos resultados encontrados, em relação aos objetivos deste trabalho e à literatura revisada. E, por fim, no quinto Capítulo, são discutidas as contribuições desta pesquisa, bem como apresentadas suas principais limitações, e a agenda de pesquisa proposta. 


\section{REFERENCIAL TÉORICO}

O objetivo deste Capítulo é apresentar o referencial teórico norteador desta pesquisa, que está organizado em três Seções. Na primeira, faz-se um breve panorama sobre modelos de efetividade dos treinamentos. Na segunda, apontam-se as principais conceituações, medidas e a importância da motivação para o treinamento. E, por fim, na terceira Seção, apresenta-se a revisão nacional efetuada sobre a motivação para o treinamento, variável critério desta dissertação, que seguiu os procedimentos relatados a seguir.

A revisão nacional sobre a motivação para o treinamento, que é objeto principal do presente estudo, procurou identificar o perfil da produção científica nacional sobre essa variável. Inicialmente, foi realizada a definição das fontes de coleta de informações. O escopo do locus de publicação dos artigos sobre motivação para o treinamento inicialmente restringiu-se a três áreas temáticas (Ciências Humanas, Ciências Sociais Aplicadas e Ciências da Saúde) da base de dados Scielo (Scientific Electronic Library Online) e aos periódicos de psicologia do portal PePSIC (Periódicos Eletrônicos de Psicologia). Posteriormente, também foram revisados os periódicos nacionais da área de Administração, Ciências Contábeis e Turismo, adotando-se como critério a seleção de todos os periódicos classificados pela Coordenação de Aperfeiçoamento de Pessoal de Nível Superior entre os estratos indicativos da qualidade - A1 E B2, que possuem linhas editorias relacionadas à gestão, totalizando 45 importantes periódicos. Os periódicos de administração selecionados foram revisados de forma individual, pois nem todos estão indexados na base de dados Scielo.

O período de publicação considerado na busca censitária por artigos englobou 10 anos (2003-2013) e a análise restringiu-se aos artigos publicados em periódicos nacionais. As palavras-chaves empregadas para a pesquisa dos artigos foram "motivação", bem como a expressão correspondente em língua inglesa "motivation"; não foram utilizadas as palavraschaves "motivação" e "treinamento" em combinação, para que houvesse a possiblidade de tentar enquadrar o maior número possível de artigos. Destaca-se que pelo menos um dos termos empregados (a palavra em inglês ou português) deveria estar presente no resumo, nas palavras-chave ou no título para ser incorporado ao escopo da pesquisa. Os resultados indicaram que, a partir do critério de busca adotado, retornaram 653 artigos na base de dados Scielo, 178 no portal PePSIC e 165 nos periódicos de Administração pesquisados. Assim, trabalhando-se inicialmente a partir de um total de 996 artigos, procedeu-se uma segunda triagem, na qual o critério de seleção foi a adoção do construto "motivação para o 
treinamento". Constatou-se que a grande parte dos artigos não tratava de assuntos relacionados à motivação para o treinamento e sim de outras temáticas, tais como: motivação no trabalho, motivação dos pais, motivação para atividades físicas, motivação para ensinar, motivação para aleitamento materno, motivação no esporte, motivação para organizar e compartilhar informação, etc. Desta forma, foram selecionados apenas 3 artigos na base de dados Scielo, 1 no portal PePSIC e 2 nos periódicos de Administração analisados. Todavia, a terceira e última triagem mostrou que os 2 artigos localizados nos periódicos de administração e o artigo localizado no portal PePSIC já haviam sido selecionados na base de dados Scielo e por isso foram descartados. Diante disso foram selecionados 3 artigos para a amostra final. A seguir é apresentado um panorama sobre a temática dos modelos de efetividade de TD\&E.

\subsection{Modelos de Avaliação de Efetividade de TD\&E}

A lógica do uso do conceito de efetividade relacionada à área de TD\&E está em consonância com a noção de aferição (PILATI, 2004). Segundo esse autor a ideia de efetividade está relacionada à investigação de um possível efeito positivo do treinamento no trabalho das pessoas e na organização.

A investigação científica em avaliação de ações de TD\&E tem sido realizada a partir do desenvolvimento de modelos que buscam relacionar diferentes variáveis relevantes com um ou vários dos indicadores de efetividade do treinamento no trabalho (PILATI, 2004). Esse autor explica que, como forma de organização, podem-se classificar os modelos de avaliação de efetividade em dois grandes grupos: a) modelos genéricos; e b) modelos específicos.

Os modelos genéricos descrevem conjuntos de variáveis relacionadas aos processos de TD\&E e geralmente influenciam a pesquisa e atuação profissional no campo, apresentando na maioria das vezes caráter somativo. Os modelos de Kirkpatrick (1976) e Hamblin (1978) são exemplos de modelos genéricos. Já os modelos específicos testam as relações entre um conjunto de variáveis específicas e determinados resultados de TD\&E no nível individual, grupal e organizacional. Borges-Andrade, Abbad e Mourão (2012) apontam que os modelos de Abbad (1999), Freitas (2005) e Mourão e Borges-Andrade (2005) são alguns exemplos de modelos específicos.

A preocupação com a efetividade dos treinamentos não é recente. Os pesquisadores e profissionais do campo de avaliação de treinamentos há muitas décadas utilizam os modelos 
de Kirkpatrick (1976) e Hamblin (1978) para avaliarem a efetividade dos programas de TD\&E, seja para uma ação isolada ou um conjunto de atividades de TD\&E (BORGESANDRADE; ABBAD; MOURÃO, 2012). Considerando esses modelos, essa avaliação partiria dos dados colhidos sobre um ou mais efeitos nos seguintes níveis: a) reação, que refere-se às opiniões dos participantes em relação ao curso e ao seu conteúdo, contemplando o grau de utilidade, dificuldade e satisfação com mesmo; b) aprendizagem, que refere-se à aquisição de conhecimentos, habilidades e atitudes - CHAS, pelos participantes; c) comportamento no cargo ou utilização no trabalho dos conhecimentos, habilidades e atitudes adquiridos nas ações de TD\&E; d) organização, ou mudanças que podem ter ocorrido no funcionamento da organização promotora das ações de TD\&E; e ainda e) valor final ou alterações na produção ou nos serviços oferecidos por essa organização ou outros benefícios sociais e econômicos. Entretanto, alguns estudos da literatura internacional realizados nas décadas de 1980 e 1990 apontam para a necessidade ampliação da visão da efetividade dos treinamentos (CAMPBELL, 1988; TANENBAUM; YUKL, 1992; MATHIEU; MARTINEAU, 1997). No Brasil esse aspecto também foi enfatizado (BORGES-ANDRADE, 1982; BORGES-ANDRADE, 2006) e outras abordagens têm sido utilizadas aos modelos de Kirkpatrick (1976) e Hamblin (1978). Entre esses modelos mais integrativos, destaca-se na literatura nacional o modelo proposto por Borges-Andrade (1982, 2006), intitulado de Modelo de Avaliação Integrado e Somativo (MAIS). Posteriormente, outros modelos também focaram numa visão mais ampliada da avaliação dos eventos de TD\&E, como o Modelo Integrado de Avaliação do Impacto do Treinamento no Trabalho - IMPACT (ABBAD, 1999). Esses modelos serão discutidos devido à relevância que possuem para a literatura de TD\&E. Esse tipo de discussão é oportuno, pois, considerando os elevados investimentos feitos em treinamentos e a crescente importância dessa área para as organizações, torna-se fundamental para os pesquisadores e para os responsáveis pela área de treinamento das organizações o melhor entendimento dos fatores que estão associados com a efetividade dos treinamentos (NGUYEN; KIM, 2013).

O Modelo de Avaliação Integrado e Somativo (MAIS), proposto por Borges-Andrade (2006), será enfatizado para os fins do presente Capítulo por ser precursor na literatura nacional dos modelos que apresentam uma visão ampliada sobre as variáveis que estão relacionadas com a efetividade das ações de TD\&E. Além disso, esse modelo possibilita que a avaliação também seja um meio de predizer os resultados e efeitos de TD\&E, o que extrapola 
as características de outros modelos que apenas julgam ou verificam se os objetivos, resultados e efeitos planejados foram alcançados.

Dessa forma, pode-se dizer que a avaliação e gestão de TD\&E por meio do modelo MAIS (BORGES-ANDRADE, 2006) possibilitam a análise e interpretação integrada das informações obtidas com o propósito de fornecer informações para o processo de tomada de decisões sobre TD\&E. Além disso, esse tipo de acúmulo de conhecimento sobre o funcionamento de TD\&E e o ambiente organizacional em que ocorrem também podem ser úteis para subsidiar a formulação de políticas e estratégias organizacionais.

De forma geral, o modelo MAIS (BORGES-ANDRADE, 2006) trata tanto dos insumos, procedimentos, processos e resultados de TD\&E, quanto do ambiente sobre o qual os eventos ou programas de ensino/aprendizagem ocorrem, conforme ilustrado pela Figura 2:

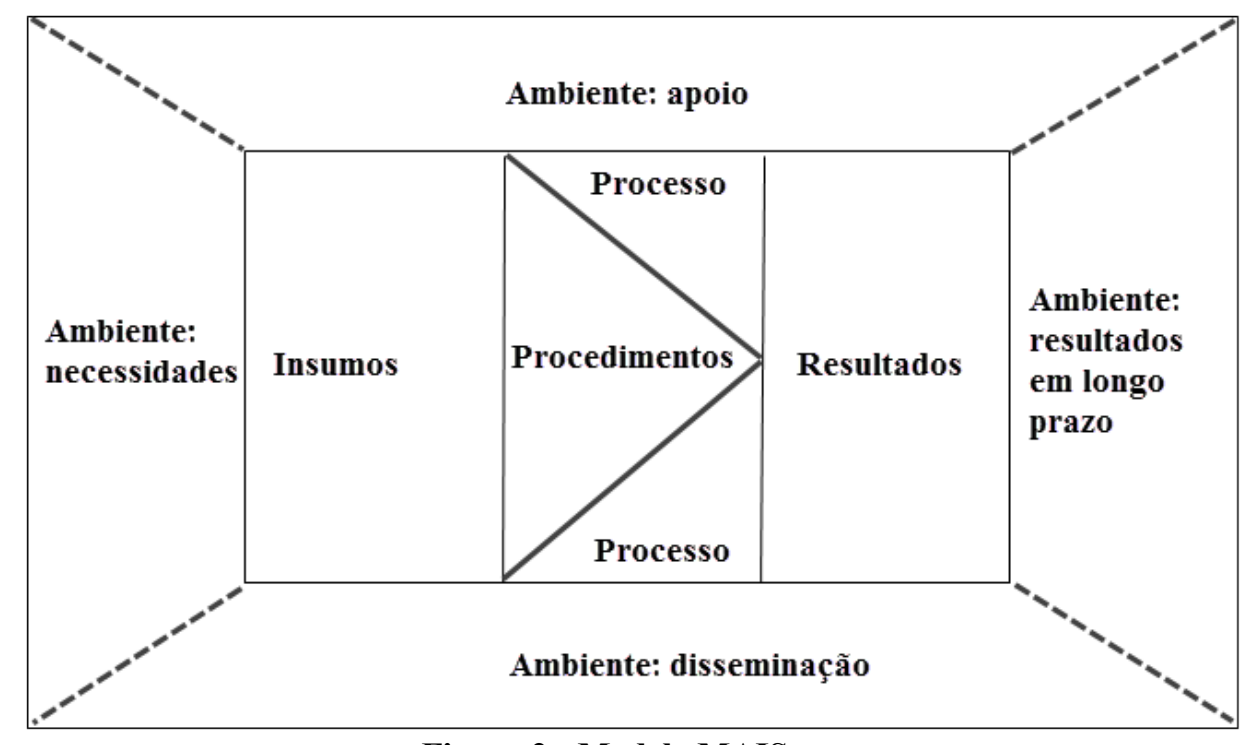

Figura 2 - Modelo MAIS

Fonte: Borges-Andrade, Abbad e Mourão (2012), pág. 23.

Esse modelo é composto por cinco componentes: a) insumos; b) procedimentos; c) processos; d) resultados; e, por fim e) ambiente. Todavia, os quatro primeiros componentes são considerados o cerne do sistema de TD\&E, já o último componente representa a inserção desse sistema no contexto da organização, sendo dividido em quatro outros subcomponentes: necessidades, suporte, disseminação e efeitos em longo prazo. Em seu estudo, BorgesAndrade, Abbad e Mourão (2012) apresentam cada um desses componentes e subcomponentes, baseando-se no trabalho de Borges-Andrade (2006). A seguir seguem as definições e exemplificações adotadas por esses autores. 
O primeiro componente, insumos, faz alusão aos fatores físicos e sociais e também aos estados comportamentais e cognitivos, que podem afetar a instrução ou os seus resultados. São exemplos de variáveis de insumo:

- $\quad$ Idade do participante de TD\&E;

- Nível socioeconômico do participante de TD\&E;

- Nível de escolaridade do participante de TD\&E;

- Cargo ocupado na organização pelo participante de TD\&E;

- Participação voluntária em TD\&E;

- Domínio de pré-requisitos de competências para o evento de TD\&E;

- $\quad$ Autoeficácia (crença dos treinandos em suas capacidades de obtenção de sucesso);

- $\quad$ Lócus de controle (atribuição de controle sobre resultados obtidos);

- Comprometimento dos participantes com sua carreira e organização;

- Prazer e sofrimento psíquicos percebidos no trabalho;

- Uso de estratégias comportamentais de aprendizagem, como busca de ajuda interpessoal ou em materiais escritos;

- Adoção de estratégias cognitivas de aprendizagem, como repetição e reflexão mentais;

- Emprego de estratégias de autoregulação, como controle emocional e monitoramento de compreensão;

- Uso pessoal de estratégias de transferência de aprendizagem no trabalho;

- $\quad$ Crenças individuais, como o cinismo, sobre o sistema de TD\&E;

- Expectativas sobre o evento e seus efeitos organização;

- Motivação pessoal para aprender;

- Percepção do participante da aplicabilidade do que será aprendido (no trabalho ou vida pessoal);

- Interesse dos participantes em aplicar, no trabalho, o que foi aprendido no evento de TD\&E;

- Valor instrumental do TD\&E para o trabalho ou vida pessoal.

O componente insumo precisa fornecer informações relevantes que possibilitem a análise de quais eventos de TD\&E sejam efetivos para a solução de problemas de desempenho ou que pelo menos contribuam para a diminuição de uma necessidade de TD\&E. As variáveis que integram esse componente podem estar significativamente associadas a 
resultados de aprendizagem de reação ou efeitos em longo prazo de TD\&E. A motivação para aprender, por exemplo, segundo a literatura de treinamento, está associada à aquisição de CHAS e com os resultados da avaliação de satisfação de eventos de TD\&E.

O segundo componente, os procedimentos, se refere às operações necessárias para favorecer ou promover os resultados instrucionais ou aprendizagem. Esse componente compreende principalmente as estratégias instrucionais mais utilizadas nos eventos de TD\&E. Alguns exemplos de procedimentos são:

- Apresentação prévia dos objetivos ao participante;

- Definição de objetivos claros e precisos;

- Sequência adequada de ensino dos objetivos;

- Estabelecimento do nível de complexidade das competências identificadas nos objetivos;

- Uso destes objetivos como organizadores avançados durante o evento;

- Adequação instrucional dos materiais de TD\&E;

- Recapitulação dos pré-requisitos em determinados momentos;

- Uso de aulas expositivas;

- Tipos de direcionamentos de aprendizagem tais como demonstração e instruções verbais;

- Utilização de exercícios práticos;

- Discussões de casos e jogos instrucionais;

- Aproximações entre as situações de TD\&E e as apresentadas no trabalho;

- Período destinado, em eventos de TD\&E, para aplicação das competências aprendidas;

- Uso de retroalimentação contingente a aplicação das competências aprendidas;

O componente procedimentos fornece os dados que permitem a descrição do sistema instrucional vigente no evento ou programa de TD\&E e, ao mesmo tempo, possibilita a verificação de sua associação com os resultados de aprendizagem ou até mesmo com os efeitos em longo prazo. A apresentação prévia dos objetivos elaborados, por exemplo, pode aumentar as expectativas dos participantes de TD\&E e em decorrência resultar em aumento de seu nível de aprendizagem. 
O terceiro componente, os processos, faz referência às informações obtidas sobre aspectos significativos do comportamento do aprendiz e que são coletadas à medida que os procedimentos são implementados. São exemplos de variáveis de processos:

- Registros de atrasos de participantes de TD\&E em relação à chegada ao evento;

- Registros de ausências de participantes de TD\&E;

- Motivação desenvolvida pelo treinando durante o evento de TD\&E;

- Relações interpessoais estabelecidas entre os participantes de TD\&E e também entre os treinandos e os instrutores, tutores e coordenadores;

- Compartilhamento de experiências;

- Quantidade de repetições de atividades realizadas pelos participantes de TD\&E até o alcance do critério preestabelecido em relação ao domínio de competências;

- Quantidade de revisões de determinadas tarefas instrucionais efetuadas pelo aprendiz;

- Resultados obtidos pelos participantes de TD\&E em testes intermediários ou exercícios práticos;

- Quantidade de participantes de TD\&E que abandonam o evento instrucional.

As informações obtidas sobre as variáveis do componente processo são importantes para o profissional de TD\&E, por representarem parte dos resultados de aprendizagem e também por permitir a realização de predições e inferências sobre resultados de TD\&E.

O quarto componente, resultados, descreve os efeitos produzidos pelos eventos ou programas de TD\&E e suas variáveis correspondem a dois níveis, reação e aprendizagem. Dessa forma, espera-se que esses efeitos surjam em decorrência dos procedimentos, logo após o término dos mesmos. São exemplos de variáveis de resultados as aquisições de competências especificadas ou não pelos objetivos e a satisfação dos treinandos com a programação, materiais instrucionais e instrutores de TD\&E.

De forma geral, as variáveis do componente resultados diferem das variáveis do componente processos por não serem desempenhos intermediários. Por exemplo, nota-se que escores de testes finais de aprendizagem são diferentes de resultados de exercícios práticos e também, que a motivação desenvolvida pelo aprendiz durante o evento de TD\&E é diferente da satisfação do aprendiz com o mesmo evento ao seu término. Além disso, as variáveis referentes ao componente resultados podem ser hipotetizadas como sendo consequências de 
quase todos os demais componentes do Modelo MAIS: necessidades, insumos, procedimentos, processos, apoio e disseminação.

Por fim, o último componente, o ambiente, representa o contexto de TD\&E, ou seja, todas as condições, atividades e eventos na sociedade, na comunidade, na organização ou na escola. Esse componente divide-se em quatro subcomponentes avaliação de necessidades, apoio, disseminação e resultados a longo prazo.

O subcomponente avaliação de necessidades se refere às lacunas existentes entre desempenhos esperados e realizados e a definição de prioridades para o preenchimento de tais lacunas. É importante enfatizar que os dados de avaliação de necessidades justificam e precedem a execução de um programa ou evento de TD\&E. O subcomponente suporte representa o conjunto de variáveis relacionadas ao lar do aprendiz, a escola, a organização ou a comunidade e que possui influência potencial sobre os insumos, procedimentos, processos e resultados. Esse subcomponente pode surgir desde o primeiro momento da avaliação de necessidades até a última ocorrência dos efeitos permanentes de TD\&E no ambiente. São exemplos de variáveis de suporte:

- Instalações disponibilizadas para a realização de TD\&E;

- Acessibilidade do participante às instalações do evento de TD\&E;

- Recursos providos pela organização ou comunidade, para a realização de TD\&E;

- Parcerias interorganizacionais, visando à efetivação do evento de TD\&E;

- Proporção entre aprendizes e instrutores ou tutores;

- Formação acadêmica e experiência de ensino dos instrutores ou tutores de TD\&E;

- Equipamentos e materiais institucionais apropriados para a execução do evento de TD\&E;

- Equipamentos e materiais organizacionais adequados para a transferência do aprendido em TD\&E para o trabalho;

- Posto de trabalho que oferece desafios ao trabalhador;

- Cultura de aprendizagem contínua presente na organização;

- Cultura de valorização do trabalhador na organização;

- Gestão de desempenho na instituição;

- Incentivo da chefia para aprendizagem e aplicação do que foi aprendido;

- Abertura dos colegas a sugestões dos participantes de eventos de TD\&E, que tentam aplicar as competências adquiridas nesses eventos; 
- Atitudes e comportamentos dos supervisores imediatos, sobre as atividades de ensino, resultados de aprendizagem e a transferência do aprendido em TD\&E.

As variáveis de suporte afetam os resultados de aprendizagem no sentido de facilitação ou restrição como, por exemplo, em um ambiente organizacional podem ocorrer situações de fornecimento de equipamentos e materiais instrucionais apropriados para execução de TD\&E, ou situações de indisponibilidade de tais recursos. Assim, as decisões sobre a adoção de um programa ou evento de TD\&E precisam considerar as características e condições de suporte que devem ser adaptadas, modificadas ou implantadas, e ainda os custos diretos e indiretos do fornecimento de suporte pela organização ou comunidade.

O subcomponente disseminação visa à adoção bem sucedida do programa ou evento de TD\&E e fornece ao profissional as informações sobre como o programa ou evento foi planejado para facilitar sua aceitação pela organização ou comunidade. São exemplos de variáveis de disseminação:

- Desenvolvimento de treinamento sobre o programa de TD\&E, voltado para a equipe de implementação e aos instrutores;

- Natureza de divulgação de informações sobre programas de TD\&E;

- Método de divulgação de informações sobre programas de TD\&E;

- Fontes de disseminação de informações sobre TD\&E na organização (recursos humanos, colegas e supervisores dos participantes);

- Canais de disseminação de informações sobre TD\&E na organização, como meios eletrônicos, visuais e auditivos;

- Conteúdos de TD\&E divulgados na organização sobre variáveis relacionadas aos insumos, procedimentos, suporte e resultados esperados.

De todos os componentes e subcomponentes do modelo MAIS, o subcomponente disseminação é o que foi menos investigado. Há evidências empíricas de que a disseminação pode influenciar positivamente a satisfação dos participantes de TD\&E quando realizada pelo Órgão de gestão de pessoas, por canal eletrônico e com informações sobre insumos e suporte administrativo (MEIRA, 2004).

O subcomponente efeitos a longo prazo faz alusão às consequências ambientais do programa ou evento de TD\&E que podem estar associadas as variáveis relacionadas a todos 
os outros componentes e subcomponentes do MAIS. Os efeitos a longo prazo incluem tanto resultados esperados quanto inesperados e, além disso, podem ser desejáveis ou indesejáveis. São exemplos de efeitos em longo prazo as mudanças de comportamento no cargo, organizacionais e indicador de valor final, conforme modelos de Kirkpatrick (1976) e Hamblin (1978).

Além da importância do modelo genérico MAIS, proposto por Borges-Andrade (2002, 2006), a literatura de TD\&E também relata o aporte às pesquisas da área proporcionado pelo modelo específico IMPACT (ABBAD, 1999). Esse modelo foi proposto para investigar o relacionamento entre variáveis relativas ao indivíduo, ao treinamento, ao contexto organizacional, aos resultados imediatos do treinamento (reação e aprendizagem) e à variável critério impacto do treinamento no trabalho e também inova em relação aos modelos tradicionais de avaliação.

Segundo Lacerda e Abbad (2003), esses dois modelos são mais abrangentes que os modelos de Kirkpatrick (1976) e Hamblin (1978), por incluírem, além dos critérios de efetividade, variáveis relacionadas ao ambiente, à clientela e aos procedimentos instrucionais. Diante disso, tanto o modelo MAIS (BORGES-ANDRADE, 1982, 2006), quanto o modelo IMPACT (ABBAD, 1999) têm sido utilizados para orientar outras pesquisas na área de TD\&E.

Finalizada essa breve contextualização sobre modelos de avaliação de treinamentos, em que foi apontada a importância dos modelos mais integradores, que incluem em sua composição variáveis até então desconsideradas por outros modelos (como as variáveis motivacionais), a seguir apresentam-se as principais conceituações, medidas e a importância da motivação para o treinamento. De forma geral, a revisão de literatura efetuada sobre essa variável pode contribuir contextualizando o tema da motivação para o treinamento em relação à efetividade dos treinamentos (MATHIEU; MARTINEAU, 1997) e subsidiará a discussão dos resultados dessa pesquisa. 


\subsection{Motivação para o Treinamento: Conceitos e Medidas desse Construto}

Antes da descrição das diversas definições de motivação para o treinamento e das diferentes formas de avaliá-la, identificadas na literatura de TD\&E, os usos técnicos do termo motivação relatados em dicionários de psicologia são apresentados na Figura 3.

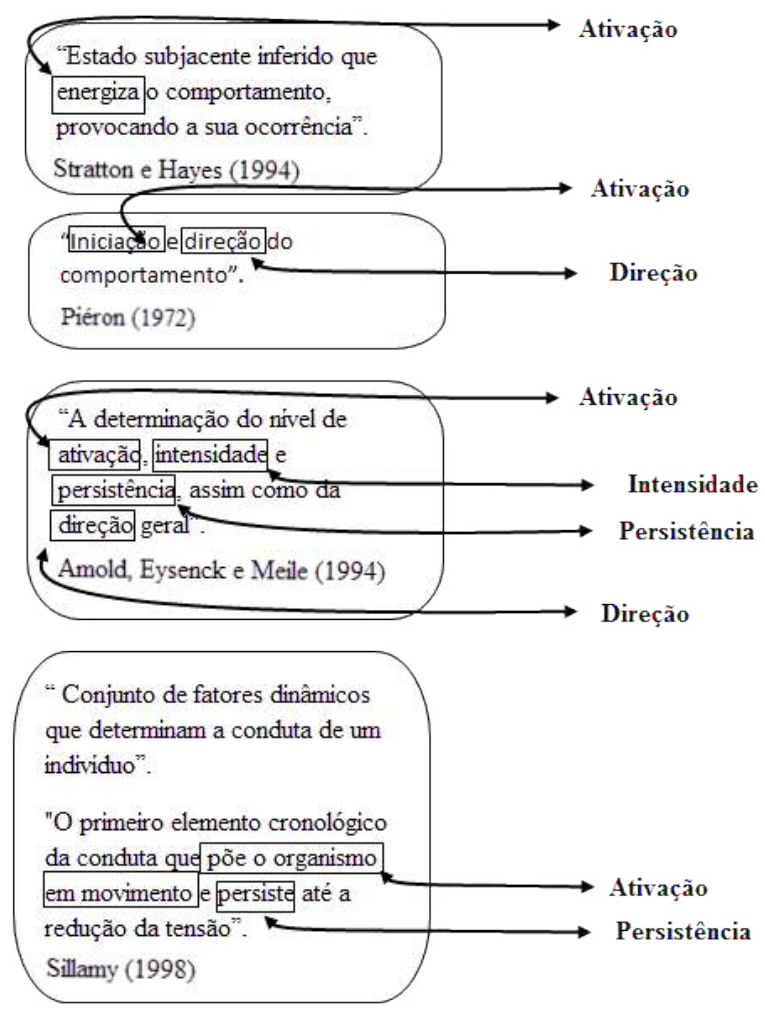

Figura 3 - Uso técnico em dicionários de psicologia do termo motivação

Fonte: Adaptado de Ribeiro (2005)

Ribeiro (2005) identificou que as diferentes conceituações encontradas de motivação em dicionários de psicologia possuem aproximação com a ideia cognitivista de ativação, direção, intensidade e persistência. Cada um desses termos foi explicado pela autora:

- A ideia de ativação refere-se ao estado inicial de estimulação em que se encontra uma pessoa para agir, que pode ser desencadeado tanto por fatores extrínsecos, quanto intrínsecos ao indivíduo e que consiste em expectativas ou necessidades. Como exemplo, a avaliação positiva do chefe ou promoção (fatores extrínsecos) e a auto-realização ou a auto-eficácia (fatores intrínsecos) podem ser possíveis fatores para a ativação da ação de um profissional trabalhar até mais tarde, fora de seu horário de expediente; 
- A direção aborda o nível de consciência da pessoa na escolha de um alvo de ação. Como exemplo, vale apontar que um indivíduo pode trabalhar até mais tarde, fora de seu horário de expediente, seja por automatismo (força do hábito) ou com a intenção ao agir (obter uma promoção).

- A intensidade faz alusão à variação da força motivacional em função de um estado anterior de carência ou um estado posterior a ser alcançado. Como exemplo, tem-se a situação em que um indivíduo acredita que, se trabalhar após seu horário, obterá uma promoção. Nesse caso, sua força motivacional pode ter sido alterada seja em função da atratividade do estado posterior a ser alcançado (ser promovido) ou pelo estado de carência anterior (nunca ter sido promovido).

- Já a persistência da ação é uma tentativa de compreensão da motivação humana pela articulação entre a ativação, direção e intensidade. A manutenção da persistência da ação é atribuída a fatores pessoais (auto-realização) ou ambientais (salário, tipo de tarefa e chefia).

Já em termos da conceituação da motivação em relação à área de TD\&E, em um estudo da literatura nacional (ABBAD; LACERDA; PILATI, 2012), foram definidos três diferentes construtos: a) motivação para aprender; b) motivação para a transferência; e c) valor instrumental do treinamento. Segundo esses autores a motivação para aprender pode ser definida como o interesse do participante em aprender o conteúdo do programa de treinamento. A motivação para a transferência, também conhecida como motivação para transferir ou motivação para aplicar o treinamento refere-se ao grau de interesse do participante em aplicar no trabalho os conteúdos aprendidos no treinamento. Por fim, o valor instrumental do treinamento, foi definido como a crença do indivíduo de que as habilidades por ele adquiridas em um curso serão úteis para adquirir recompensas de várias naturezas (instrumentalidade), levando-se em conta a importância que o indivíduo atribui a cada recompensa (valência).

De forma geral, os resultados de pesquisa sobre a motivação para o treinamento demonstram consistência, porém apresentam ambiguidade na definição e medição da motivação para o treinamento (ZANIBONI; FRACCAROLI; TRUXILLO; BERTOLINO; BAUER, 2011). A revisão realizada por esses autores aponta que o construto motivação para o treinamento tem sido definido de diversas formas, por diferentes autores, como: a) um desejo específico do treinando para aprender o conteúdo do treinamento (NOE, 1986; NOE; 
SCHMITT, 1986); b) o esforço aplicado no treinamento para aprender o conteúdo do curso (HICKS; KLIMOSKI, 1987); c) a percepção do treinando de que tendo um bom desempenho no programa de treinamento o conduzirá a uma melhor performance no trabalho e, consequentemente, para os resultados valorizados (MATHIEU; TANNENBAUM; SALAS, 1992); d) a medida em que o funcionário é incentivado a participar de atividades de treinamento e aprendizagem do programa e usar o conhecimento adquiridos no trabalho (MATHIEU; MARTINEAU, 1997); e) a direção, intensidade e persistência da aprendizagem no contexto de treinamento (COLQUITT; LEPINE; NOE, 2000); f) a intenção de se esforçar para seguir um programa de treinamento específico (CAMPBELL; KUNCEL, 2001); g) a intensidade e a persistência dos esforços que os treinandos aplicam em atividades de desenvolvimento orientadas a aprendizagem antes, durante e depois do treinamento (BURKE; HUTCHINS, 2007); h) e da intenção de realizar um objetivo, ou seja, investir esforço para trabalhar e aprender durante o programa (SMITH; JAYSURIYA; CAPUTI; HAMMER, 2008).

O que se observa é que em algumas situações, a motivação para o treinamento é concebida com base em descrições fenomenológicas, tais como: desejo, interesses e envolvimento no processo de aprendizagem e, por outro lado, a motivação para o treinamento também tem sido conceituada com base em potenciais implicações comportamentais, tais como: quantidade e persistência do esforço para aprender e a intenção de atingir metas (ZANIBONI et al., 2011). Essa situação tem impactado os tipos de medidas utilizadas para avaliar a motivação para o treinamento. Assim, além da análise sobre qual a variável motivacional é mais indicada para a busca de respostas sobre questões que envolvem a motivação, também é fator crítico a escolha de qual a medida utilizar para avaliar a motivação dos indivíduos e qual a teoria motivacional a ser escolhida como fundamento teórico para o estudo desse fenômeno na área de TD\&E.

De forma geral, a motivação para o treinamento tem sido avaliada essencialmente de acordo com três abordagens (MATHIEU; MARTINEAU, 1997): I) de medidas somativas diretas; II) de medidas de auto-eficácia; e III) de medidas que consideram a teoria da expectância. Em seu estudo esses autores explicam como essas medidas se diferenciam. A primeira abordagem trata de um modo direto para avaliar a motivação do treinando por meio da coleta de auto-avaliações sobre como estão motivados antes de entrarem no treinamento e também sobre como estão motivados para aplicarem o que aprenderam em treinamento em 
seus locais de trabalho. A segunda abordagem refere-se ao julgamento dos treinandos sobre suas capacidades de organizar e executar cursos de ações necessários para o alcance de desempenhos designados. E, por fim, a terceira abordagem de medida de motivação para o treinamento deriva da literatura sobre a teoria da valência-instrumentalidade-expectativa (VIE) de Vroom (1964). A expectativa faz alusão à crença pessoal sobre a capacidade de aquisição de uma determinada habilidade, a instrumentalidade é tida como a percepção de que a aquisição dessa habilidade levará a resultados específicos e a valência refere-se à importância atribuída pelo indivíduo a esses resultados.

Lacerda e Abbad (2003), utilizaram uma medida somativa direta, a motivação para aprender, por meio de uma escala composta por 5 itens, para mensurar o interesse e a disposição do indivíduo em aprender o conteúdo do programa de treinamento. Meneses e Abbad (2010), usaram uma medida de auto-eficácia, composta por 15 itens, para avaliar as crenças gerais dos indivíduos acerca de suas capacidades para obter sucesso. Já Pilati (2004) utilizou a força motivacional, uma medida que considera a teoria da expectância de Vroom (1964), para avaliar as expectativas do indivíduo a respeito de efeitos decorrentes de seus próprios comportamentos e do valor relativo que atribui a cada resultado analisado, por meio do produto de três variáveis: valência, instrumentalidade e expectância. A primeira e a segunda variável foram mensuradas pela escala de Lacerda (2002) e a terceira foi avaliada por medida produzida em seu estudo. Assim, diante dessa diversidade de conceito e medidas, sem uma clara explicação do que se trata o construto motivação para o treinamento, e sem uma reflexão sobre quais as melhores medidas para avaliar este fenômeno, pode ocorrer que os resultados de pesquisas sobre a relação da motivação para o treinamento sejam interpretados erroneamente.

Nesse trabalho, a definição constitutiva da motivação para o treinamento foi inspirada na teoria de Vroom (1964) e nos trabalhos de Lacerda (2002) e Pilati (2004). Dessa forma, o construto motivação para o treinamento foi definido como "a crença do indivíduo de que as habilidades por ele adquiridas em um treinamento serão úteis para alcançar recompensas profissionais que valoriza, levando-se em conta suas expectativas de que possa atingir as recompensas desejadas por meio dos treinamentos". Já definição operacional da motivação para o treinamento, corresponderá ao produto de três variáveis, a valência, a instrumentalidade e a expectância, que serão medidas pela escala produzida por Lacerda (2002), intitulada de escala de Valor Instrumental do Treinamento, acrescida de um item de 
avaliação sobre a expectância, conforme proposto por Pilati (2004). Neste estudo, foi utilizada a abordagem de medida de motivação para o treinamento derivada da literatura sobre a teoria da valência-instrumentalidade-expectativa (MATHIEU; MARTINEAU, 1997), especificamente baseando-se na teoria de Vroom (1964). Essa forma de mensuração trata a motivação como um processo de decisão, em que o indivíduo analisa aspectos situacionais, contextuais e disposicionais, antes de decidir quanto esforço aplicará em determinada ação (ABBAD; LACERDA; PILATI, 2012). Como esta pesquisa investiga a relação entre às características individuais da clientela de TD\&E, o suporte à aprendizagem e à motivação para o treinamento, tal estratégia foi avaliada como apropriada.

São várias as teorias de motivação voltadas para o treinamento (LACERDA; ABBAD, 2003). Todavia, há resultados de pesquisas anteriores (NOE; SCHMITT, 1986; COLQUITT; SIMMERING, 1998) que sinalizam que os aspectos motivacionais relacionados ao treinamento devem ser examinados sob o prisma da teoria da expectância de Vroom (1964). A escolha desse tipo de abordagem pode ser justificada, dentre outros fatores, pela sua utilidade para o estudo dos processos subjacentes a motivação.

De forma geral, por ser uma teoria de processo, a teoria da expectância de Vroom (1964) parte do pressuposto de que os indivíduos focalizam sua atenção nas sucessivas etapas do fenômeno motivacional, em suas percepções e perspectivas no estabelecimento de metas e objetivos pessoais e, principalmente, nos mecanismos conscientes da tomada de decisões. Diferentemente das teorias de conteúdo, que partem da determinação das necessidades humanas para explicar os fenômenos motivacionais, porém, sem discutir sobre as operações psicológicas, tanto conscientes como inconscientes, que podem estar inseridas neste processo. Apesar das teorias de conteúdo possuírem mais repercussão nos ambientes de trabalho, as teorias de processo são consideradas como cientificamente mais apropriadas (TRIBET; RUSH, apud PÉREZ-RAMOS, 1990).

Por fim, tendo em vista que apenas nas últimas décadas os pesquisadores têm voltado sua atenção para o estudo da motivação para o treinamento (COLQUITT; LEPINE; NOE, 2000), tornam-se relevantes as iniciativas de investigação das pesquisas já realizadas sobre esse construto. A seguir apresenta-se a revisão efetuada visando à caracterização do perfil da produção científica nacional sobre a motivação para o treinamento. 


\subsection{Revisão da Literatura Nacional sobre Motivação para o Treinamento}

Esta Seção está dividida em duas Subseções. Na primeira, são descritas as dimensões e categorias de enquadramento empregadas no estudo. A segunda apresentam os resultados obtidos em relação ao cenário das publicações nacionais a partir do enfoque de cada uma das três dimensões analíticas propostas: (i) identificação e demografia do artigo; (ii) finalidade do artigo; e (iii) tipificação metodológica do artigo. Espera-se, com esta revisão, oferecer contribuições ao debate teórico e prático sobre o tema.

\subsubsection{Dimensões e Categorias de Enquadramento Empregadas no Estudo}

Após a análise de conteúdo da amostra final, para tratamento dos artigos localizados foram definidas três dimensões analíticas: (i) identificação e demografia da publicação; (ii) finalidade dos artigos teórico e teórico-empíricos; e (iii) tipificação metodológica do estudo. Estas dimensões são compostas por diversas categorias, que são explicadas adiante.

A dimensão que trata da identificação e demografia do artigo teve como categorias de análise: nomes dos periódicos de origem dos artigos; ano da publicação do artigo; autores; instituição de origem dos autores; grau de escolaridade mais elevado dos autores; área de formação relativa ao grau de escolaridade mais elevado dos autores; e quantidade de referências bibliográficas, que foram fragmentadas em obras nacionais e internacionais.

A classificação da finalidade de investigação dos artigos teóricos e teóricos empíricos não foi estipulada a priori, tendo em vista que esta opção poderia conduzir a um enquadramento imperfeito dos artigos encontrados. Desta forma, as dimensões temáticas foram definidas após a coleta dos dados e sistematização dos estudos. Para fazer a definição das categorias temáticas utilizou-se inicialmente a análise de três tópicos dos artigos (títulos, resumos e palavras-chave), porém, após a análise dos resultados desta etapa, optou-se pela leitura de toda a obra de cada artigo, tanto pela dificuldade encontrada em entender a temática dos textos, quanto pelo fato da extensão da amostra não dificultar tal procedimento. Considerando os resultados encontrados pela análise da leitura de cada artigo, optou-se pela classificação dos artigos em duas áreas temáticas. A primeira que engloba os artigos que tratam de temas ligados a estudos sobre Modelos de avaliação de TD\&E ou instrumentos de medidas, totalizando 2 artigos e a segunda que englobou o único artigo que abordou a 
temática da produção de investigação de variáveis preditoras da motivação para o treinamento.

Em relação à última categoria de análise proposta para este estudo, a tipificação metodológica do artigo, a amostra de artigos foi classificada quanto: natureza da pesquisa (qualitativa, quantitativa ou quali-quanti); aos métodos de pesquisa utilizados; aos instrumentos de coleta e às técnicas de análise de dados.

\subsubsection{Resultados}

No intuito de facilitar a apresentação dos resultados obtidos esta Subseção foi dividida para possibilitar o enfoque de cada uma das três dimensões analíticas propostas: (i) identificação e demografia do artigo; (ii) finalidade do artigo; e (iii) tipificação metodológica do artigo. Além disso, ao final desta Subseção são apresentadas as lacunas identificadas nas pesquisas e os problemas de investigação.

\subsubsection{Identificação e Demografia da Produção Nacional sobre Motivação para o Treinamento}

No que concerne à identificação e demografia autoral da produção, a distribuição da produção dos periódicos analisados mostrou-se concentrada na produção realizada por dois autores $(100 \%)$, dessa forma nenhum pesquisador publicou sem coautoria. Esse dado reforça o argumento de que as parcerias de coautoria continuam sendo importantes geradores de produção científica, inclusive em outras áreas de estudo (CINTRA; MUNCK; VIEIRA, 2012). Os autores possuem em sua maioria a titulação de doutorado (50\%) e nenhum autor era aluno de Mestrado ou possuía apenas a graduação como titulação máxima, de acordo com dados obtidos por meio dos próprios artigos ou currículo lattes. Já a formação dos pesquisadores concentrou-se totalmente na área de psicologia (100\%). As referências foram baseadas principalmente por obras internacionais (51,76\%). As referências bibliográficas utilizadas para a produção dos artigos (taxa aproximada $=28,33 /$ artigo) são oriundas em sua maioria de obras internacionais. De todas as obras incorporadas aos textos $44(51,76 \%)$ são provenientes de fontes internacionais e $41(48,24 \%)$ são de fontes nacionais. 
A produção nacional sobre motivação para o treinamento tem se fundamentado principalmente pela produção científica internacional. A Tabela 1 mostra o resumo da identificação e demografia da produção nacional sobre a motivação para o treinamento.

Tabela 1 - Identificação e Demografia

\begin{tabular}{|c|c|c|c|c|c|}
\hline Número de Autores & $\mathrm{n}$ & $\%$ & Áreas Principais de Formação & $\mathrm{n}$ & $\%$ \\
\hline 1 Autor & 00 & 00 & Psicologia & 06 & 100,0 \\
\hline 2 Autores & 03 & 100,0 & Administração & 00 & 00 \\
\hline 3 Autores & 00 & 00 & Saúde & 00 & 00 \\
\hline Titulação Máxima dos Autores & $\mathrm{n}$ & $\%$ & Outras & 00 & 00 \\
\hline Doutorado & 03 & 50,00 & Não informado & 00 & 00 \\
\hline Aluno de Doutorado & 01 & 16,67 & & & \\
\hline Mestrado & 02 & 33,33 & & & \\
\hline Aluno de Mestrado & 00 & 00 & Referências Utilizadas & $\mathrm{n}$ & $\%$ \\
\hline Graduação & 00 & 00 & Internacionais & 44 & 51,76 \\
\hline Não informado & 00 & 00 & - Artigos & 44 & 51,76 \\
\hline Titulação Máxima do $1^{\circ}$ Autor & $\mathrm{n}$ & $\%$ & - Outros & 00 & 00 \\
\hline Doutorado & 01 & 33,33 & & & \\
\hline Aluno de Doutorado & 01 & 33,33 & Nacionais & 41 & 48,24 \\
\hline Mestrado & 01 & 33,33 & - Artigos & 41 & 48,24 \\
\hline Aluno de Mestrado & 00 & 00 & - Outros & 00 & 00 \\
\hline Graduação & 00 & 00 & & & \\
\hline
\end{tabular}

Baseando-se nos critérios de busca descritos na metodologia deste estudo, uma quantidade ínfima de artigos foi localizada nas bases de dados e periódicos revisados, 3 artigos no total. Desse resultado, 2 artigos foram encontrados na revista RAC e 1 artigo no periódico Paidéia (Ribeirão Preto). Apenas os anos 2003 e 2010 tiveram publicações sobre a temática da motivação para o treinamento, considerando o período revisado que se estendeu de 2003 a 2013 (Tabela 2).

Tabela 2 - Periódicos e Quantitativo de Publicações

\begin{tabular}{|c|c|c|c|c|c|c|c|c|c|c|c|c|}
\hline \multirow[b]{2}{*}{ Nome do Periódico } & \multicolumn{11}{|c|}{ Ano } & \multirow[b]{2}{*}{ Total } \\
\hline & 03 & 04 & 05 & 06 & 07 & 08 & 09 & 10 & 11 & 12 & 13 & \\
\hline $\mathrm{RAC}$ & 2 & 0 & 0 & 0 & 0 & 0 & 0 & 0 & 0 & 0 & 0 & 0 \\
\hline Paidéia (Ribeirão Preto) & 0 & 0 & 0 & 0 & 0 & 0 & 0 & 1 & 0 & 0 & 0 & 0 \\
\hline Total & 2 & 0 & 0 & 0 & 0 & 0 & 0 & 1 & 0 & 0 & 0 & 3 \\
\hline
\end{tabular}

Fonte: Elaborado pelo autor

Ainda sobre a identificação e a demografia da produção nacional sobre motivação para o treinamento, a UnB aparece como a líder em representantes que estudam a temática (40\%) 
quando analisada a autoria das publicações revisadas, as outras organizações tiveram apenas um autor cada uma, conforme apresentado pela Tabela 3.

Tabela 3 - Autor e Instituição de Origem

\begin{tabular}{ll}
\hline \multicolumn{1}{c}{ Autor } & Instituição de Origem \\
\hline Abbad, G. & UnB \\
Lacerda, E. R. M. & SEBRAE NACIONAL \\
Marins, J. & ESTÁCIO DE SÁ \\
Meneses, P. P. M. & UnB \\
Mourão, L. & UNIVERSO \\
\hline
\end{tabular}

Fonte: Elaborado pelo autor

\subsubsection{Finalidade da produção nacional sobre motivação para o treinamento}

No que concerne à classificação da finalidade dos artigos, visando ao melhor enquadramento, as dimensões temáticas foram definidas após a coleta dos dados e sistematização dos estudos, optando-se pela definição de duas áreas temáticas (Tabela 4). A primeira engloba os artigos que tratam de temas ligados a estudos sobre Modelos de avaliação de TD\&E ou instrumentos de medidas, totalizando 2 artigos dentre os 3 que compuseram o banco de dados desta pesquisa. A segunda temática engloba o único artigo que abordou a temática da produção de estudos variáveis preditoras de motivação para o treinamento.

Tabela 4 - Finalidade Temática e Natureza das Investigações

\begin{tabular}{lrrrrr}
\hline \multicolumn{1}{c}{ Temática Central dos Artigos } & $\mathrm{n}$ & \multicolumn{1}{c}{$\%$} & Temática Central dos Artigos & $\mathrm{n}$ & $\%$ \\
\hline $\begin{array}{l}\text { Modelos de avaliação de TD\&E e/ou } \\
\text { instrumentos de medidas; }\end{array}$ & 2 & 66,67 & $\begin{array}{l}\text { Variáveis preditoras de } \\
\text { Motivação para o Treinamento; }\end{array}$ & 1 & 33,33 \\
& & & & & \\
\hline $\begin{array}{l}\text { Natureza dos Artigos Teórico- } \\
\text { Empíricos }\end{array}$ & $\mathrm{n}$ & $\%$ & Natureza dos Artigos Teóricos & $\mathrm{n}$ & $\%$ \\
\hline - Descritivo & 3 & 100,0 & $\bullet$ Revisões/Discussões & 0 & 0 \\
- Exploratório & 0 & 0 & $\bullet$ Construções/ Proposições & 0 & 0 \\
- Exploratório e descritivo & 0 & 0 & & & \\
\end{tabular}

Fonte: Elaborado pelo autor

Por fim, acerca da natureza dos artigos ressalta-se que as pesquisas localizadas foram enquadradas como teórico-empíricas $(100 \%)$ e trataram de estudos descritivos. 


\subsubsection{Tipificação metodológica da produção nacional sobre motivação para o treinamento}

No que tange aos métodos, procedimentos e técnicas adotados no desenvolvimento das pesquisas analisadas sobre motivação para o treinamento, os resultados obtidos estão dispostos na Tabela 5.

Tabela 5 - Tipificação Metodológica das Investigações

\begin{tabular}{|c|c|c|c|c|c|}
\hline Metodologia de Pesquisa & $\mathrm{n}$ & $\%$ & Natureza da Pesquisa & $\mathrm{n}$ & $\%$ \\
\hline Survey & 3 & 100,0 & Qualitativa & 0 & 00 \\
\hline Estudo de caso & 0 & 00 & Quantitativa & 3 & 100,0 \\
\hline Pesquisa bibliográfica & 0 & 00 & Quali-Quanti & 0 & 00 \\
\hline Pesquisa documental & 0 & 00 & Instrumentos de Pesquisa & & \\
\hline Múltiplas & 0 & 00 & Pesquisa documental & 0 & 00 \\
\hline Setor de Inserção & $\mathrm{n}$ & $\%$ & Entrevista & 0 & 00 \\
\hline Público & 1 & 33,33 & Grupo Focal & 0 & 00 \\
\hline Privado & 1 & 33,33 & Questionário & 3 & 100,0 \\
\hline Público e Privado & 1 & 33,33 & Não informado & 0 & 00 \\
\hline Terceiro Setor & 0 & 00 & & & \\
\hline Técnicas Analíticas & $\mathrm{n}$ & $\%$ & Abrangência da Pesquisa & $\mathrm{n}$ & $\%$ \\
\hline Análise de Conteúdo & 0 & 00 & Uma Organização & 1 & 33,33 \\
\hline Estatística Descritiva & 0 & 00 & Duas Organizações & 0 & 00 \\
\hline Estatística Inferencial & 3 & 100,0 & Três ou Mais Organizações & 2 & 66,67 \\
\hline Análise combinada & 0 & 00 & Não informado & 0 & 00 \\
\hline Análise do Discurso & 0 & 00 & & & \\
\hline Outros & 0 & 00 & & & \\
\hline
\end{tabular}

Fonte: Elaborado pelo autor

No que concerne aos métodos de pesquisa aplicados para alcance dos objetivos propostos pelos estudos, prevaleceu o survey (100\%). Em relação aos resultados da classificação do setor de inserção ficou evidenciado que as investigações se deram no setor público $(33,33 \%)$, privado $(33,33 \%)$ ou misto entre público e privado $(33,33 \%)$. No terceiro setor não houve realização de estudos. Quanto às técnicas de análises de dados utilizadas, houve concentração da estatística inferencial (100\%). Já em relação aos desenhos de pesquisa, os 3 artigos encontrados (100\%) trabalharam apenas com a abordagem quantitativa.

Quanto aos Instrumentos de Pesquisa para coleta de dados, todos os trabalhos relataram apenas o uso de questionários (100\%). Em relação à abrangência da pesquisa, a maior parte dos estudos envolveu três ou mais organizações $(66,67 \%)$.

\subsubsection{Problemas de Investigação e Lacunas Identificadas nas Pesquisas}

De maneira geral os artigos localizados trataram da temática de Modelos de avaliação de TD\&E, instrumentos de medidas ou variáveis preditoras de motivação para o treinamento. 
O estudo de Meneses e Abbad (2003) buscou investigar as contribuições das variáveis individuais do próprio treinamento e do suporte à transferência na explicação da variabilidade de impacto do treinamento no trabalho. Ressalta-se que em relação às variáveis individuais (que inclui a motivação para o treinamento) esses autores utilizaram as variáveis demográficas gênero, faixa etária, nível de instrução, estado civil, organização de origem, religião e filhos (sim ou não) e ainda as variáveis auto-eficácia, lócus de controle e motivação para o treinamento. Nenhuma dessas variáveis contribui significativamente para a explicação de heteroavaliação do impacto do treinamento no trabalho e apenas a variável auto-eficácia contribuiu significativamente para a explicação de auto-avaliação de impacto do treinamento no trabalho. Ainda em relação aos resultados desse estudo, somente suporte psicossocial percebido pelos participantes e auto-eficácia e suporte psicossocial percebido pelas chefias e colegas de trabalho e quantidade de instrutores por turma, contribuíram, respectivamente, na explicação da variabilidade de auto e heteroavaliação de impacto do treinamento. Assim, nota-se que a variável motivação para o treinamento não foi preditora de resultados de treinamentos neste estudo, apesar da literatura apontar que essa variável é fundamental para contribuir com o aperfeiçoamento dos modelos de avaliação de efetividade dos treinamentos.

Lacerda e Abbad (2003) tiveram como objetivos a testagem de um modelo de avaliação de impacto do treinamento no trabalho e a construção/aperfeiçoamento e validação de instrumentos de medidas. Essa pesquisa foi desenvolvida em três etapas: (1) a construção e validação da escala de valor instrumental do treinamento; (2) o aperfeiçoamento e a validação das escalas de motivação para aprender, motivação para transferir e suporte pré-treinamento; e (3) a investigação das variáveis preditoras de impacto do treinamento no trabalho de cursos de uma Organização Pública do Distrito Federal, no contexto de treinamentos presenciais. os resultados das etapas 1 e 2 da investigação mostraram que as escalas produzidas e aperfeiçoadas apresentaram índices psicométricos adequados. Essa pode ser considerada uma das principais contribuições do trabalho dessas autoras. Na etapa 3 desse mesmo estudo, a análise de regressão múltipla demonstrou que três variáveis foram explicativas de autoavaliação de impacto do treinamento no trabalho: a) suporte psicossocial; b) valor instrumental do treinamento; e c) reação do participante ao instrutor.

Já o estudo de Mourão e Marins (2010) teve como principal objetivo verificar se as características da clientela, do treinamento e das organizações influenciam nos resultados da motivação para aprender. O modelo construído por essas autoras teve como variáveis 
antecedentes o número de funcionários, o tempo de trabalho, as crenças sobre TD\&E, o tipo de instrutor e o tipo de treinamento. A análise dos dados coletados foi realizada utilizando-se estatísticas descritivas e teste de regressão múltipla padrão. Em relação aos resultados, as crenças em relação ao sistema de TD\&E, tipo de instrutor e tempo de empresa foram preditoras da motivação para aprender. Quanto às contribuições dessa pesquisa, Mourão e Marins (2010) ressaltam que esse trabalho inovou ao testar se as crenças em relação ao treinamento são capazes de interferir positiva ou negativamente nos níveis de motivação para aprender dos trabalhadores e, além disso, por verificar se esse nível de motivação é afetado por outras variáveis como tempo de trabalho, número de funcionários da empresa, tipo de treinamento e tipo de instrutor.

Considerando as lacunas de pesquisa identificadas por essa revisão, primeiramente recomenda-se como agenda de pesquisa a produção de novos trabalhos empíricos que especifiquem tanto os preditores da motivação para o treinamento, quanto façam novas testagens de como as características individuais e situacionais influenciam a motivação para o treinamento. Outros autores já haviam mencionado a importância dessas linhas de pesquisa (COLQUITT; LEPINE; NOE, 2000), porém na literatura nacional, são escassos os estudos realizados sobre a temática da motivação para o treinamento. Outra agenda de pesquisa sugerida refere-se ao setor de inserção dos estudos. Como nos estudos identificados nehuma organização do terceiro setor foi investigada, sugerem-se estudos sobre a motivação para o treinamento nesse tipo de organização. Além disso, embora as pesquisas nacionais sobre motivação para o treinamento tenham utilizado escalas validadas para a coleta de dados sobre as variáveis motivacionais investigadas, considerando que essa revisão identificou que no Brasil ainda há poucos instrumentos de medidas desenvolvidos sobre escalas de motivação para o treinamento, o que já havia sido apontado por outros estudos (LACERDA E ABBAD, 2003), nota-se que a linha de pesquisa sobre construção e validação de instrumentos de motivação para o treinamento, ainda carece da atenção dos pesquisadores da área de TD\&E. Por fim, também seria interessante a produção de novos estudos que fizessem uso de outras fontes de coletas de dados para a avaliação da motivação para o treinamento, pois todas as pesquisas encontradas nessa revisão utilizaram de questionários para a obteção de dados sobre a motivação para o treinamento. 
Finalizada essa revisão bibliográfica, que visou identificar o perfil da produção científica nacional sobre a motivação para o treinamento, variável critério desse estudo, a seguir apresenta-se a revisão efetuada sobre os principais preditores desse construto.

\subsection{Variáveis Preditoras da Motivação para o Treinamento.}

Os trabalhos empíricos sobre a motivação para o treinamento têm sido caracterizados por dois enfoques: a) especificação dos preditores da motivação para o treinamento, analisando seu relacionamento com a aprendizagem; ou b) construção e testagem de modelos compreensíveis de como as características individuais e situacionais influenciam a motivação para o treinamento e os resultados de aprendizagem (COLQUITT; LEPINE; NOE, 2000).

Em seu estudo Colquitt, LePine e Noe (2000) realizaram uma meta-análise sobre a motivação para o treinamento e sumarizaram a literatura de 20 anos sobre o tema, em seu estudo foram apresentados os antecedentes dessa variável e sua relação com os resultados de aprendizagem, tais como o conhecimento declarativo, aquisição de habilidades e transferência. Os resultados obtidos revelaram que diversas variáveis pertencentes ao grupo das características individuais da clientela são preditoras da motivação para o treinamento: lócus de controle, conscienciosidade, ansiedade, envolvimento com o trabalho, comprometimento organizacional, planejamento de carreira, exploração de carreira, autoeficácia, valência e idade. Além disso, esses autores identificaram que as variáveis suporte do chefe, suporte dos pares e clima para a transferência, variáveis pertencentes ao grupo das características situacionais, foram preditoras da motivação para o treinamento.

Diante da importância das características situacionais e das características individuais da clientela para a motivação para o treinamento, a seguir será apresentado o resultado de uma breve revisão sobre cada uma dessas variáveis antecedentes.

\subsubsection{Características Situacionais}

A literatura sobre TD\&E aponta que as variáveis de suporte afetam a participação e o rendimento do participante e ainda influenciam a transferência das habilidades aprendidas em treinamento para o trabalho (BORGES-ANDRADE et al., 2013).

Muitas das ações de TD\&E não apresentam os resultados desejados devido à falta de suporte ao uso de novas habilidades no trabalho (ABBAD; BORGES-ANDRADE, 2014). 
Segundo esses autores, as organizações que oferecem os recursos materiais e o suporte apropriados ao desempenho exemplar provavelmente terão melhores resultados de treinamentos do que àquelas que costumam responsabilizar apenas os indivíduos pelo nível de competência que apresentam.

De forma geral os aspectos do ambiente de trabalho do treinando que podem afetar a motivação para o treinamento e a efetividade das ações instrucionais incluem: a) os sistemas de manutenção de treinamentos; b) os fatores psicológicos/sociais; e c) as restrições situacionais (MATHIEU; MARTINEAU, 1997). Para esses autores, os sistemas de manutenção de treinamentos referem-se às intervenções da organização para reforçar e assegurar a continuidade da transferência do treinamento, como por exemplo, o sistema de remuneração baseado em competências. Os fatores psicológicos/sociais tratam das forças interpessoais ou psicológicas sociais que podem influenciar na motivação para o treinamento antes ou após o retorno ao trabalho e que também operam e influenciam na efetividade dos treinamentos, ora intituladas como clima, cultura ou relações interpessoais. Já as restrições situacionais referem-se às características do ambiente que interferem ou restringem o desempenho dos indivíduos (PETERS; O’CONNOR; EULBERG, apud MATHIEU; MARTINEAU, 1997) e incluem fatores tangíveis como: a) adequação de informações relacionadas ao trabalho; b) ferramentas e equipamentos; c) materiais e suprimentos; d) apoio orçamentário e financeiro; e, por fim, e) disponibilidade de tempo.

Uma importante variável que tem sido utilizada em pesquisas nacionais sobre avaliação de apoio trata-se do suporte à transferência (ABBAD et al., 2012). Segundo esses autores, esse construto avalia o apoio recebido pelo egresso do treinamento para aplicar no trabalho, as habilidades adquiridas durante o curso e sua mensuração pode ser feita pelo egresso, por seus chefes, colegas e pares por meio de dois fatores: a) suporte psicossocial à transferência; e b) suporte material à transferência. O suporte psicossocial a transferência avalia o apoio gerencial, social e organizacional à aplicação de novas aprendizagens no trabalho e o fator suporte material a transferência avalia a qualidade, quantidade e disponibilidade de recursos materiais e financeiros, além da qualidade e adequação do ambiente físico do local de trabalho à transferência do treinamento. Outra variável de apoio identificada na literatura nacional, foi e que foi utilizada no modelo de pesquisa dessa dissertação é o suporte à aprendizagem, que avalia o suporte psicossocial (colegas, pares e chefes) à aprendizagem e à aplicação de novas habilidades no ambiente de trabalho, adquiridas por meio de atividade estruturadas, como 
treinamentos, e também por aprendizagens ocorridas em situações organizacionais não estruturadas ou intencionais (COELHO JR., 2004).

Na literatura revisada não foram encontrados relatos empíricos da variável suporte à aprendizagem em relação à motivação para o treinamento, dessa forma, essa revisão tratará de construtos correlatos ou de outras variáveis de contexto. Diversos construtos que tratam de variáveis de suporte já foram investigados em relação à motivação para o treinamento (FACTEAU; DOBBINS; RUSSELL; LADD; KUDISCH, 1995).

Algumas pesquisas têm buscado identificar quais variáveis situacionais influenciam a motivação para o treinamento. Há resultados que mostram que o clima para a transferência está positivamente associado com a motivação para aprender e com a motivação para transferir (WEN; LIN, 2014) e que o suporte do chefe, o suporte dos pares e o clima para a transferência são preditores da motivação para o treinamento (COLQUITT; LEPINE; NOE, 2000).

A literatura também relata que fatores organizacionais, tais como clima e apoio social, influenciam a motivação para participar de treinamento através de seus efeitos sobre as percepções de eficácia e a utilidade dos resultados de treinamento para desempenho no trabalho e carreira (BEIER; KANFER, 2010). Além disso, segundo esses autores, o clima organizacional, as características do trabalho, o apoio do gerente e variáveis individuais (como a auto-eficácia) são potenciais influenciadores da motivação para a transferência.

Em seu estudo, Carvalho-Silva (2008) investigou a relação entre o clima social da organização, a motivação dos indivíduos para aprender e o uso de estratégias para aprender informalmente no trabalho. Analisando os dados coletados de duas organizações públicas federais, a autora identificou em sua investigação a existência de correlações entre a medida motivacional, as dimensões do clima social da organização e as estratégias de aprendizagem no trabalho. Outro resultado mencionado por essa autora é que mesmo em contexto desfavorável, os indivíduos pesquisados relataram altos níveis de motivação para a aprendizagem. Por outro lado, de acordo com a literatura de TD\&E, nem sempre os indivíduos podem superar as restrições situacionais e tampouco possuem o poder para modificar condições adversas de trabalho (ABBAD; BORGES-ANDRADE, 2014). 
Já o estudo produzido por Facteau et al. (1995) investigou o suporte social para o treinamento e transferência percebido por um amostra final de 967 gestores por meio de um construto multidimensional composto por quatro fatores: percepção de apoio dos subordinados, percepção de apoio dos pares, percepção de apoio dos supervisores e percepção de apoio dos gestores do alto nível hierárquico. Os resultados da pesquisa realizada por esses autores indicaram que a percepção de apoio dos supervisores relacionou-se positivamente com a motivação pré-treinamento, que a percepção de apoio dos subordinados dos gestores e dos gestores do alto nível hierárquico relacionou-se negativamente com a motivação prétreinamento e que a percepção de apoio dos pares não se relacionou com a motivação prétreinamento.

A literatura relata que treinandos que recebem mais suporte dos supervisores possuem maior motivação para o treinamento (CHIABURU; TEKLEAB, 2005). Em seu estudo Tharenou (2001) identificou que o suporte do supervisor, em combinação com a motivação através da expectância e a motivação para aprender predizem a participação em atividades de treinamento e desenvolvimento. Os resultados sugerem que o comportamento do supervisor segundo a percepção dos subordinados é o aspecto mais importante do ambiente de trabalho para a participação em treinamento e desenvolvimento. Esse autor explica que a importância do apoio do supervisor comparado a outros aspectos do ambiente de trabalho, talvez ocorra por ser uma variável mais proximal à participação dos empregados em ações de treinamento e desenvolvimento. Além disso, esse autor sustenta que: a) as organizações precisam estabelecer relações entre resultados extrínsecos (como pagamento, promoção e segurança no trabalho) e os conhecimentos, habilidades e capacidades adquiridos das atividades de treinamento e desenvolvimento e garantir que os trabalhadores estão conscientes dessa relação para que aumentem suas participações nessas atividades; b) o suporte dos supervisores é um fator chave para a participação do trabalhador em atividades de treinamento e desenvolvimento e os supervisores precisam encorajar seus subordinados a participarem dessas atividades e aplicarem no ambiente de trabalho as habilidades adquiridas; c) considerando que os trabalhadores que já possuem maior motivação para o treinamento podem acessar mais o suporte fornecido pelo supervisor, os gerentes precisam assistir todos os seus trabalhadores a responder ao suporte fornecido.

Foxon (1993) também destaca o papel do suporte recebido pelos egressos dos treinamentos por seus supervisores. Segundo esse autor, os supervisores exercem mais 
influência do que os colegas de trabalho sobre a decisão do aprendiz sobre a implementação do que foi aprendido em treinamento. Facteau et al. (1995) também identificaram em sua pesquisa que os aprendizes que perceberam um maior grau de apoio de seus superiores imediatos para o treinamento relataram maior motivação para participar e aprender com a formação. Além disso, a literatura também aponta que a investigação de características de suporte psicossocial, tanto o oferecido por supervisores, quanto pelos pares, possibilita a análise da influência do ambiente organizacional quanto ao estímulo à aprendizagem dos indivíduos, principalmente no que concerne aos fatores facilitadores de aquisição e da aplicação de novas habilidades e conhecimentos no trabalho (COELHO JR.; ABBAD; TODESCHINI, 2005).

De forma geral, o ambiente organizacional pode influenciar a aprendizagem estimulando ou dificultando sua ocorrência (ABBAD et al., 2012). Diante desse cenário, em estudo sobre a força motivacional em contexto de aprendizagem informal nas organizações, Ribeiro (2005) sugere que futuras pesquisas deveriam incluir pelo menos as variáveis situacionais descritas na literatura atual, em estudos destinados a medir a motivação para a aprendizagem, possibilitando assim a realização do teste do impacto de variáveis de suporte nas taxas de motivação para aprendizagem. A presente dissertação atende a essa agenda de pesquisa, alterando-se, porém, o contexto da pesquisa para a aprendizagem formal. A seguir, apresenta-se breve revisão sobre as variáveis da categoria das características individuais da clientela de TD\&E.

\subsubsection{Características Individuais}

As condições externas organizacionais e instrucionais não são as únicas que podem determinar a aprendizagem no trabalho, certas características dos aprendizes também podem influenciá-la (ABBAD; BORGES-ANDRADE, 2014). As características da clientela que têm recebido mais atenção da literatura de TD\&E são: as variáveis demográficas (tais como sexo, idade, escolaridade e tempo de serviço); as auto-referentes, que se baseiam na noção de que o indivíduo é capaz de exercer controle considerável sobre sua vida (auto-eficácia, autoconceito, auto-estima, lócus de controle); as motivacionais (tais como valor instrumental do treinamento, motivação para aprender, motivação para transferir); e as características cognitivo-comportamentais, como as estratégias cognitivas (MENESES et al., 2006). 
Em seu estudo Colquitt, LePine e Noe (2000) identificaram que diversas variáveis pertencentes ao grupo das características individuais da clientela são preditoras da motivação para o treinamento: lócus de controle, conscienciosidade, ansiedade, envolvimento com o trabalho, comprometimento organizacional, planejamento de carreira, exploração de carreira, auto-eficácia, valência e idade.

Todavia, o estudo de Facteau et al. (1995) investigaram as variáveis comprometimento organizacional, exploração de carreira e planejamento de carreira em relação à motivação pré-treinamento e os resultados desse estudo mostraram que apenas o comprometimento organizacional relacionou-se positivamente e de forma significativa com a motivação prétreinamento. Segundo esses autores, os indivíduos que estão mais comprometidos com os valores e objetivos da organização possuem níveis mais elevados de motivação prétreinamento.

A revisão de literatura efetuada por Beier e Kanfer (2010) relata que algumas características individuais, tais como envolvimento com o trabalho, comprometimento organizacional, comprometimento com o trabalho e diferenças individuais em traços de personalidade geralmente estão relacionadas com a motivação e a escolha de se envolver em atividades de treinamento. Além disso, esses autores defendem a importância da realização de pesquisas que visem a entender influências afetivas sobre a escolha de participar do treinamento, a transferência de habilidades aprendidas no treinamento para o trabalho e que explorem as relações entre as emoções e os processos de autoregulação, que são importantes durante a execução do treinamento.

As pesquisas sobre variáveis demográficas e os resultados de treinamentos apresentam resultados inconsistentes (MATHIEU; MARTINEAU, 1997). Essa afirmação corrobora outros resultados de pesquisas. No estudo de Tharenou (2001) os indivíduos do sexo feminino apresentaram maior motivação para o treinamento que indivíduos do sexo masculino. Todavia, no estudo de Ribeiro (2005), os resultados indicaram que a variável gênero não foi preditiva da motivação através da expectância. Essa autora testou a relação entre a motivação através da expectância e as variáveis antecedentes gênero, idade, tempo de serviço no cargo e na organização, formação acadêmica, ramo de atuação na organização, área de trabalho, cargo que desempenha e natureza da organização. Os resultados do estudo dessa autora identificaram que apenas três dessas variáveis (variáveis individuais) foram preditoras da força motivacional: graduação em pedagogia; graduação em saúde e área de atuação em RH. 
Assim, com base nesses breves relatos de pesquisa que foram encontrados na literatura revisada, acredita-se que com o teste do modelo desse estudo será possível descrever e analisar relações entre variáveis individuais que são pouco estudadas de forma central e que não apresentam resultados consistentes de pesquisas. As variáveis demográficas, apesar de serem mencionadas em estudos sobre treinamentos, muitas vezes são testadas apenas como fontes de controle estatístico (MENESES; ABBAD, 2003). 


\section{METODOLOGIA DE PESQUISA}

Este Capítulo destina-se à descrição dos seguintes assuntos: a) caracterização da organização investigada; b) população e amostra pesquisada; c) instrumentos de pesquisa; d) procedimentos de coleta de dados; e, por fim, e) procedimentos de análise de dados.

\subsection{Caracterização da Organização}

Esta pesquisa foi realizada no INCRA. A escolha de se trabalhar com os dados dessa Organização ocorreu pela facilidade de acesso do pesquisador a documentos, servidores e ocupantes de cargo de chefia. Além disso, ressalta-se que o apoio recebido do INCRA para a coleta dos dados e a obtenção de autorização para utilização e publicação de informações de caráter público sobre a organização foram decisivos para que esta pesquisa fosse conduzida.

O INCRA é uma autarquia federal criada em 1970, possui autonomia administrativa e financeira e tem como missão principal promover a redistribuição de terras obtidas pelo atributo constitucional da desapropriação por interesse social para fins de reforma agrária. Esse Órgão possui os direitos, competências e atribuições estabelecidos pela Lei $n^{\circ}$ 4.504, de 30 de novembro de 1964 (Estatuto da Terra) e por legislação complementar, em especial as que regem a promoção e a execução da reforma agrária e da colonização.

Monte (2006) afirma que a missão do INCRA na época de sua criação foi orientada para promover a ocupação de espaços vazios do território nacional, particularmente na Região Amazônica. Para esse autor, as ações desse Órgão foram realizadas por meio de processos de colonização e de regularização fundiária, seguindo a vertente do desenvolvimento agrícola, que prevaleceu durante o período da ditadura militar em desfavor da reforma agrária estipulada no Estatuto da Terra, em 1964. Em termos produtivos, a intervenção do Estado voltou-se para o modelo de desenvolvimento de modernização da agricultura conhecido por modernização conservadora, que foi amparado por volumosas quantidades de crédito, incentivos fiscais e outras modalidades de subsídios implementadas de acordo com cada região. Esse autor ainda sustenta que as consequências desse modelo foram "o aumento da concentração da terra, o agravamento das relações sociais, o surgimento de conflitos agrários e uma acentuação das desigualdades sociais no campo" e afirma que na década de 80 , com a redemocratização do País e a mobilização social, o processo de intervenção por meio do instrumento da desapropriação foi intensificado, porém não produzindo os efeitos previstos no 
Estatuto da Terra (Lei $\mathrm{n}^{\mathrm{o}}$ 4.504/1964). E por fim, relata que o INCRA já foi submetido a várias conjunturas e que o Órgão já teve sua missão e a sua estrutura organizativa alteradas várias vezes.

Atualmente, a missão do INCRA é "implementar a política de reforma agrária e realizar o ordenamento fundiário nacional, contribuindo para o desenvolvimento rural sustentável". A instituição visa ser referência internacional de soluções de inclusão social (INCRA, 2015) e para alcançar a visão mencionada se tem orientado por cinco diretrizes estratégicas. A primeira diretriz é a democratização do acesso a terra. A implementação da reforma agrária precisa promover a democratização do acesso a terra mediante a criação e implantação de assentamentos rurais sustentáveis, a regularização fundiária de terras públicas e, ao mesmo tempo, executar o gerenciamento da estrutura fundiária do país, contribuindo para o desenvolvimento sustentável, a desconcentração da estrutura fundiária, a redução da violência e da pobreza no campo e a promoção de igualdade. A segunda diretriz, a participação social, enfatiza que a reforma agrária será implementada de forma participativa reafirmando os princípios da legalidade, impessoalidade, moralidade, publicidade e eficiência, contribuindo para o fortalecimento de parcerias e da sociedade civil organizada. A terceira diretriz, a fiscalização da função social, afirma que a reforma agrária será implementada de forma a fiscalizar a função social dos imóveis rurais, contribuindo para a capacitação dos assentados, o fomento da produção agroecológica de alimentos e a inserção nas cadeias produtivas. A quarta diretriz refere-se à qualificação dos assentamentos. A reforma agrária será implementada buscando a qualificação dos assentamentos rurais, por meio do licenciamento ambiental e do acesso à infraestrutura básica, ao crédito, à assessoria técnica e social e à articulação com as demais políticas públicas, em especial a educação, saúde, cultura e esportes, contribuindo para o cumprimento das legislações ambientais e trabalhistas e para a promoção da paz no campo. E, por fim, a quinta diretriz, refere-se à titulação dos territórios quilombolas, o que implica que a reforma agrária também será implementada pela destinação das terras públicas, a demarcação e titulação das terras ocupadas por comunidades tradicionais e quilombolas e que o Órgão gerenciará a estrutura fundiária nacional pelo conhecimento da malha fundiária mediante o cadastramento e certificação dos imóveis rurais, contribuindo para as políticas de inclusão social e desenvolvimento sustentável. 
Para exercer suas atribuições o INCRA investiu R\$ 1.395.000.000,00 (um bilhão, trezentos e noventa e cinco milhões), ao longo do ano de 2014, nas ações finalísticas do Órgão. Além disso, com a integração de políticas públicas do Governo Federal em 2014, foi possível a execução de outros serviços e apoio aos assentados que totalizaram o montante de R\$ 1,7 bilhão em várias ações, tais como: Bolsa Verde; Fomento (Plano Brasil Sem Miséria); Programa Minha Casa, Minha Vida; Programa Água para Todos; Bolsa Família; Programa de Aquisição de Alimentos (PAA); PAA Leite; Programa Terra Forte (INCRA, 2015).

Os investimentos do INCRA possibilitaram que no ano de 2014 fossem criados 145 projetos de assentamentos, distribuídos em 415.436 hectares, propiciando que 32.019 famílias fossem assentadas. Em termos de capacidade, apenas os projetos de assentamentos criados em 2014, segundo o INCRA podem receber 12 mil famílias. De acordo com o INCRA, além dos assentamentos criados, em 2014 também foram decretados pela Presidência da República 30 imóveis para a reforma agrária, com área de 66,3 mil hectares e com capacidade para receber 1.789 famílias.

Além da criação e gestão de programas, projetos e ações, dotados de recursos para sua execução, atenção também precisa ser dada às ações de capacitação dos servidores, que são os responsáveis pelo cumprimento da missão do Órgão e alcance dos resultados almejados. Conforme regimento interno do INCRA, essa tarefa está sob a responsabilidade da Diretoria de Gestão Administrativa (DA) do Órgão. A DA tem dentre suas incumbências a tarefa de gerir as atividades relacionadas ao sistema federal de recursos humanos.

Subordinada à DA encontra-se a Coordenação Geral de Gestão de Pessoas (CGGP) que propõe, implementa e avalia a política de desenvolvimento de recursos humanos do INCRA e que estende suas orientações a todas as Superintendências Regionais, escritórios e Unidades Avançadas do Órgão. No que se refere ao desenvolvimento de pessoas no INCRA, aplica-se o disposto no Decreto $n^{0}$ 5.507, de 23 de fevereiro de 2006, que institui a Política e as Diretrizes para o Desenvolvimento de Pessoal da administração pública federal direta, autárquica e fundacional e que regulamenta dispositivos da Lei no 8.112, de 11 de dezembro de 1990 . Ressalta-se que a Política Nacional de Desenvolvimento de Pessoal deve ser implementada por todos os órgãos e entidades da administração pública federal direta, autárquica e fundacional. Assim, o desenvolvimento de pessoal do INCRA precisa estar alinhado com as seguintes finalidades estipuladas por essa política: I - melhoria da eficiência, eficácia e qualidade dos serviços públicos prestados ao cidadão; II - desenvolvimento permanente do 
servidor público; III - adequação das competências requeridas dos servidores aos objetivos das instituições, tendo como referência o plano plurianual; IV - divulgação e gerenciamento das ações de capacitação; e V - racionalização e efetividade dos gastos com capacitação. Todas essas diretrizes estão alinhadas a uma boa gestão do desenvolvimento de pessoas e a última delas refere-se à racionalização e efetividade dos gastos com a capacitação. Dessa forma, é oportuno relatar como têm sido geridos os gastos com ações de capacitação dos servidores do INCRA.

Já em relação à execução orçamentária da ação de capacitação do INCRA, em 2014, foram empenhados R \$ 2.064.826,00 (dois milhões, sessenta e quatro mil, oitocentos e vinte e seis reais) e o valor executado foi de $\mathrm{R} \$ 1.762 .997,00$ (um milhão, setecentos e sessenta e dois mil, novecentos e noventa e sete reais). Quanto ao valor empenhado para despesas com as atividades de capacitação dos servidores do INCRA, quase metade do valor total $(44,53 \%)$ corresponde a pagamentos de Pessoa Jurídica (PJ), ou seja, valores empenhados para pagamentos a instituições que prestam serviços de capacitação, como universidades e centros de ensino. A segunda maior fonte de despesas com as atividades de capacitação foram com despesas de diárias (29,84\%). A terceira maior despesa do INCRA com suas atividades de capacitação foram os gastos com passagens $(23,44 \%)$. A quarta maior despesa corresponde aos pagamentos do objeto Pessoa Física (1,93\%), que correspondem aos pagamentos de instrutorias, sejam elas internas ou externas, através das GECC's (Gratificação por Encargos de Curso ou Concurso). E, por fim, as despesas com material de consumo responderam pela menor parcela dos valores empenhados para as despesas da ação de capacitação do INCRA $(0,20 \%)$.

Ainda referindo-se à área de desenvolvimento de pessoal do INCRA, de acordo com o Relatório de Gestão do Órgão de 2013, foram oferecidas pelo órgão 2.253 oportunidades de capacitação, que totalizaram 103.593 horas. No que diz respeito ao tipo de ação, observa-se que as oportunidades de capacitação foram agrupadas em duas modalidades: aperfeiçoamento e educação formal. 
Em relação ao total das ações de capacitação, 96\% ocorreram na modalidade de aperfeiçoamento, e apenas $4 \%$ foram realizadas na modalidade de educação formal, conforme Tabela 6.

Tabela 6 - Oportunidades de Capacitação por Tipo de Ação

\begin{tabular}{lll}
\hline Tipo de Ação & $\begin{array}{l}\mathrm{N}^{\circ} \text { de Oportunidades de } \\
\text { Capacitação }\end{array}$ & $\begin{array}{l}\text { Horas de capacitação } \\
\text { oferecidas }\end{array}$ \\
\hline Aperfeiçoamento & 2.151 & 57.178 \\
\hline Aprendizagem em serviço & 75 & 2.114 \\
Curso & 1.293 & 37.850 \\
Grupo Formal de estudo & 3 & 64 \\
Oficina de trabalho/Workshop & 156 & 2.548 \\
Palestra & 51 & 160 \\
Seminário* & 511 & 13.585 \\
Treinamento em serviço & 54 & 648 \\
Visita técnica & 6 & 192 \\
Simpósio & 2 & 17 \\
\hline Educação Formal & 102 & 46.418 \\
\hline Curso & 2 & 720 \\
Doutorado & 14 & 10.252 \\
Especialização & 70 & 28.131 \\
Graduação & 1 & 0 \\
Mestrado & 15 & 7.315 \\
\hline Total Geral & 2.253 & 103.596 \\
\hline
\end{tabular}

*Inclui congressos, conferências, fóruns, encontros ou outros similares.

Fonte: Elaborado pelo autor com base em dados fornecidos pelo INCRA

Já em relação às modalidades de capacitação, as ações de TD\&E foram classificadas em três modalidades de ensino: à distância, presencial e semipresencial. Em relação ao total das oportunidades de capacitação, ressalta-se que $95,21 \%$ das oportunidades foram realizadas na modalidade presencial e apenas $4,79 \%$ foram realizadas na modalidade à distância ou semipresencial, conforme Tabela 7.

Tabela 7 - Oportunidades de Capacitação por Modalidade

\begin{tabular}{lll}
\hline Modalidade & $\mathrm{N}^{\mathrm{o}}$ de Oportunidades de & $\begin{array}{l}\text { Horas de capa citação } \\
\text { oferecidas }\end{array}$ \\
& Capacitação & 6.853 \\
Á distância & 103 & 95.424 \\
Presencial & 2.145 & 1.319 \\
Semi-presencial & 5 & 103.596 \\
\hline Total geral & 2.253 &
\end{tabular}

Fonte: Elaborado pelo autor com base em dados fornecidos pelo INCRA 
Por fim, a Tabela 8 apresenta resumo das capacitações realizadas em termos do tipo de instituição executora das ações de treinamentos. As maiores oportunidades de capacitação foram produzidas pelo próprio Órgão e representaram $73,55 \%$ do total. Já as escolas de governo responderam pelo menor número de oportunidades, totalizando apenas $4,84 \%$ do total.

Tabela 8 - Oportunidades de Capacitação por Tipo de Instituição

\begin{tabular}{lll}
\hline Modalidade & $\begin{array}{l}\mathrm{N}^{0} \text { de Oportunidades de } \\
\text { Capacitação }\end{array}$ & $\begin{array}{l}\text { Horas de capa citação } \\
\text { oferecidas }\end{array}$ \\
\hline Escola de Governo & 109 & 5.146 \\
Instituição Pública - Próprio Órgão & 1.657 & 44.043 \\
Instituição Pública - Outros Órgãos & 219 & 30.387 \\
Instituição Privada & 268 & 24.020 \\
\hline Total geral & 2.253 & 103.596 \\
\hline
\end{tabular}

Fonte: Elaborado pelo autor com base em dados fornecidos pelo INCRA

Realizada a caracterização da organização de estudo, a seguir apresenta-se a delimitação da população e as características da amostra.

\subsection{População e Amostra}

A população deste estudo é composta por servidores públicos ocupantes de cargos de nível médio e superior, lotados em Brasília, nas unidades do INCRA-Sede, que já participaram de algum treinamento promovido pelo INCRA (interno ou externamente) até o momento da coleta de dados, que se estendeu de 24 de setembro a 14 de novembro de 2014 . Apesar da população ter sido delimitada em termos de cargos ocupados e obrigatoriedade de participação prévia em treinamentos, não foi possível identificar o tamanho da população do estudo.

Inicialmente, pretendia-se estender essa pesquisa para todos os servidores ocupantes de cargos de nível médio e superior lotados em Brasília, nas unidades do INCRA-Sede em setembro de 2014, o que perfazia um total de 391 servidores. Entretanto, como o modelo de investigação proposto consistia na testagem da relação entre variáveis individuais e de suporte à aprendizagem sobre a motivação para o treinamento, a população do estudo restringiu-se aos servidores que passaram por experiências de treinamento na organização. Em razão da ausência de dados atualizados dos servidores que já haviam participado previamente em algum treinamento promovido pela área de recursos humanos, optou-se por encaminhar um email para todos os 391 servidores e incluir no documento referente ao termo de consentimento (Anexo I) o esclarecimento de que, devido ao recorte da pesquisa, somente estariam aptos a 
responder ao questionário os servidores que já tivessem participado de algum treinamento promovido pelo INCRA (interno ou externamente) até o momento da coleta de dados.

Os servidores ocupantes de cargos de nível fundamental não foram considerados nesse estudo, pois a escala de pesquisa utilizada para medir a motivação para o treinamento, variável critério da pesquisa, é autoaplicável apenas em respondentes com escolaridade igual ou superior ao ensino médio completo (ABBAD; LACERDA; PILATI, 2012). Pela ausência de dados atualizados sobre o nível de escolaridade dos servidores, optou-se por vincular a aplicação dos questionários a servidores ocupantes de cargos de nível médio e superior, mesmo tendo em vista que alguns servidores com cargo de nível fundamental poderiam ter na ocasião grau de formação mais elevado do que os requisitos necessários para o exercício de seus cargos.

Após a delimitação da população, o tipo de amostra a ser selecionada foi tomado conjuntamente com a organização. Como o Órgão não possuía a relação atualizada dos servidores que já haviam participado de ações de capacitação no INCRA foi inviabilizada a amostragem aleatória. Diante disso, a amostragem de pesquisa considerada a mais adequada para o estudo proposto foi a não probabilística por conveniência. Nessa modalidade, o pesquisador seleciona os elementos a que tem acesso, admitindo que eles possam de alguma maneira representar a população (GIL, 1999).

Assim, a amostra foi composta por todos os respondentes voluntários da população, que declararam atender aos critérios propostos: de serem detentores de um grau de escolaridade mínima (ensino médio completo); e de terem participado previamente em algum treinamento promovido pelo Órgão. Quanto maior a amostra, melhores são as chances de obtenção de um modelo de regressão confiável (FIELD, 2009). O instrumento foi enviado apenas aos servidores que atendiam ao primeiro critério da delimitação da amostra, ou seja, que eram ocupantes de cargos de nível médio e superior e que estavam lotados em unidades do INCRASede. E, ainda, na primeira página da pesquisa foi incluído o termo de consentimento, que continha o esclarecimento de que, devido ao recorte da pesquisa, somente estariam aptos a responder ao questionário os servidores que já tivessem participado de algum treinamento promovido pelo INCRA (interno ou externamente) até o momento da coleta de dados, ou seja, que atendiam ao segundo critério estabelecido para a composição da amostra. Optou-se por fazer o levantamento de participação em treinamentos junto ao termo de consentimento pela necessidade de prévia obtenção de concordância do servidor em participar da pesquisa, 
mesmo tendo ciência da possibilidade de que alguns servidores do Órgão que já participaram de treinamentos poderiam decidir não participar da pesquisa.

Foram coletados 161 questionários respondidos, decidiu-se por descartar os questionários em branco e incompletos (83 casos considerando as duas condições), tendo em consideração que o número de questões deixadas em branco nos questionários incompletos foi elevado. Após a identificação e eliminação dos outliers univariados e multivariados (HAIR; BLACK; BABIN; ANDERSON; TATHAM, 2009), restaram 155 questionários válidos.

Ainda que não definida probabilisticamente, a amostra teve de ser dimensionada com o intuito de se atender aos objetivos antes propostos. Diferentes critérios podem ser adotados para se estimar o número de casos que deve compor uma determinada amostra (FIELD, 2009). O cálculo do tamanho da amostra necessária para a análise de fatores considerou os resultados de pesquisas que indicam que fatores com 10 ou mais cargas maiores do que 0,40 são confiáveis se o tamanho da amostra é maior do que 150 casos (GUDAGNOLI; VELICER apud FIELD, 2009). Em relação ao teste de regressão, os dois critérios mais comuns são possuir 15 casos de dados para cada previsor utilizado no modelo ou, no mínimo, 10 casos de dados por previsor (FIELD, 2009). Seguindo o critério de maior rigor, para esse estudo o tamanho sugerido encontrado foi de 60 casos (4 previsores). Por outro lado, Field (2009) acrescenta que Green (1991) apresenta duas regras práticas para o tamanho mínimo aceitável de uma amostra: a primeiro tendo como referência o teste do modelo como um todo, e a segunda que toma por base os testes individualizados dos previsores do modelo. Caso o modelo seja testado como todo, a recomendação é que a amostra tenha um tamanho mínimo de $50+8 \mathrm{~K}$, onde $\mathrm{k}$ é o número de previsores. Se for realizada a testagem dos previsores individualmente, o tamanho mínimo de amostra recomendado é de $104+$ k. Field (2009) argumenta que na maioria das investigações o interesse é testar tanto o modelo quanto a contribuição dos previsores. Nesse caso, segundo esse autor, Green (1991) recomenda que o tamanho da amostra mínima seja calculado pelas duas formas e que seja adotada a que fornecer o valor mais alto. O valor encontrado foi de 82 casos pela primeira regra e de 108 casos pela segunda regra. Considerando que o procedimento apresentado por Green (1991) recomenda que o tamanho mínimo da amostra seja de 108 casos, e que o critério de 15 casos de dados para cada previsor recomenda 60 casos, no presente estudo, optou-se pelo método de maior rigor, ou seja, 108 casos. Assim, os 155 casos válidos representam um valor superior aos critérios estabelecidos para o cálculo do tamanho mínimo da amostra para a análise de 
fatores e para os testes de regressão executados. A Tabela 9 apresenta o perfil da amostra selecionada.

Tabela 9 - Perfil da Amostra para a Análise de Fatores e Testagem do Modelo Empírico da Dissertação

\begin{tabular}{|c|c|c|c|c|c|}
\hline Sexo & $\mathrm{n}$ & $\%$ & Ocupação de Cargo de Chefia & $\mathrm{n}$ & $\%$ \\
\hline Feminino & 85 & 54,8 & Sim & 47 & 30,3 \\
\hline Masculino & 70 & 45,2 & Não & 108 & 69,7 \\
\hline Idade & $\mathrm{n}$ & $\%$ & Lotação & $\mathrm{n}$ & $\%$ \\
\hline 21 a 30 anos & 10 & 6,5 & DD & 17 & 11,0 \\
\hline 31 a 40 anos & 46 & 29,7 & DT & 17 & 11,0 \\
\hline 41 a 50 anos & 31 & 20,0 & DF & 31 & 20,0 \\
\hline 51 a 60 anos & 60 & 38,7 & DA & 43 & 27,7 \\
\hline Acima de 60 anos & 8 & 5,2 & $\mathrm{DE}$ & 14 & 9,0 \\
\hline & & & AUDIT & 5 & 3,2 \\
\hline & & & PFE & 4 & 2,6 \\
\hline & & & PRESI/GABI & 13 & 8,4 \\
\hline & & & SRFA & 11 & 7,1 \\
\hline Escolaridade & $\mathrm{n}$ & $\%$ & Tempo de Serviço no INCRA & $\mathrm{n}$ & $\%$ \\
\hline Ensino Médio & 23 & 14,8 & de 1 a 5 anos & 31 & 20,0 \\
\hline Ensino Superior & 66 & 42,6 & de 6 a 10 anos & 47 & 30,3 \\
\hline Pós-Graduação lato sensu & 51 & 32,9 & de 11 a 15 anos & 2 & 1,3 \\
\hline Pós-Graduação Stricto Sensu (M) & 14 & 9,0 & de 16 a 20 anos & 11 & 7,1 \\
\hline Pós-Graduação Stricto Sensu (D) & 1 & 0,6 & de 21 a 25 anos & 6 & 3,9 \\
\hline & & & de 26 a 30 anos & 8 & 5,2 \\
\hline & & & mais de 30 anos & 50 & 32,3 \\
\hline
\end{tabular}

Fonte: Elaborado pelo autor com base em dados fornecidos pelo INCRA

No que concerne ao perfil sócio demográfico e profissional, constata-se, conforme a Tabela 9, que a maioria dos respondentes é do sexo feminino (54,8\%), faixa etária de 51 a 60 anos $(38,7 \%)$ e possui curso superior. No que se refere à unidade de trabalho, verifica-se que a maioria trabalha na Diretoria Administrativa do Órgão (27,7\%). Quanto à ocupação de cargos de chefia/supervisão, nota-se que a maioria dos participantes da pesquisa não ocupa cargos de confiança $(69,7 \%)$. Já em relação ao tempo de serviço, grande parte dos respondentes pertence à faixa de servidores com mais 30 anos de trabalho no INCRA $(32,3 \%)$.

\subsection{Instrumentos de Pesquisa}

Nessa Seção são descritos os dois instrumentos que foram utilizados para a coleta de dados da amostra final que foi selecionada para o estudo proposto. $\mathrm{O}$ primeiro instrumento a ser caracterizado é o suporte à aprendizagem e o segundo a escala de motivação para o treinamento.

\subsubsection{Suporte à Aprendizagem}

O construto suporte à aprendizagem foi definido por Abbad, Lacerda e Pillati (2012) e Coelho Jr. (2004) como a percepção do respondente sobre o apoio oferecido por pares e 
chefias ao empregado que busca aprender e aplicar novas habilidades nas suas rotinas de trabalho.

Coelho Jr. (2009) validou a escala de suporte a aprendizagem, que, em sua versão original, apresenta um total de 31 itens, associados a uma escala de frequência tipo Likert, de 11 pontos, na qual 0 (zero) corresponde a nunca e 10 (dez) a sempre, sendo composta por dois fatores: suporte à aprendizagem da chefia e unidade de trabalho; e suporte à aprendizagem provido por colegas de trabalho.

Segundo Coelho Jr. (2009), a medida de suporte à aprendizagem contou com índices psicométricos adequados. O fator suporte à aprendizagem da chefia e unidade de trabalho apresenta alto índice de consistência interna e itens com cargas fatoriais oscilando entre 0,59 e 0,97. De forma semelhante, o fator suporte à aprendizagem dos colegas também apresenta alto índice de consistência interna e itens com cargas fatoriais oscilando entre 0,76 e 0,98. Os índices psicométricos da escala de suporte à aprendizagem para a amostra utilizada em sua validação são apresentados na Tabela 10 .

Tabela 10 - Índices Psicométricos da Escala de Suporte à Aprendizagem

\begin{tabular}{lrcc}
\hline Nome do fator & Itens & $\begin{array}{l}\text { Indice de } \\
\text { Precisão }\end{array}$ & $\begin{array}{l}\text { Carga } \\
\text { Fatorial }\end{array}$ \\
\hline $\begin{array}{l}\text { Suporte à aprendizagem da Chefia } \\
\text { E Unidade de Trabalho }\end{array}$ & 25 & 0,98 & 0,59 a 0,97 \\
\hline$\%$ da variância explicada $=64,78 \%$ & & & \\
\hline Suporte à aprendizagem dos Colegas & 06 & 0,97 & 076 a 0,98 \\
\hline$\%$ da variância explicada $=10,3 \%$ & & \\
\hline
\end{tabular}

Fonte: Coelho Jr. (2009)

Para o alcance do objetivo específico do presente estudo, que visou adaptar e verificar evidências de validade estatística do instrumento de medida de suporte à aprendizagem elaborado por Coelho Jr. (2009) foram agregados a essa escala 3 itens, que fazem menção a treinamentos, devido ao interesse em investigar o suporte provido às ações de aprendizagem nas organizações que fossem de natureza formal e informal. Esses itens foram obtidos da escala produzida por Coelho Jr. (2004), e um deles originalmente possuía enunciado negativo e teve seu significado invertido, seguindo a mesma linha de Coelho Jr. (2009), ou seja, adoção apenas de itens de conotação positiva. Além disso, foi efetuada a alteração da pontuação da escala de frequência tipo Likert, de 11 pontos, na qual 0 (zero) corresponde a nunca e 10 (dez) a sempre, para uma frequência Likert de 5 pontos, na qual 0 (zero) corresponde a nunca e cinco (5) a sempre. Essa alteração objetivou a harmonização da pontuação dessa escala com o 
instrumento utilizado para mensurar a motivação para o treinamento, que é associada a uma escala tipo Likert de cinco pontos (LACERDA, 2002).

Em síntese, a escala validada por esse estudo e que foi utilizada para a mensuração do suporte à aprendizagem contou com 34 itens associados a uma escala Likert de 5 pontos, na qual 0 (zero) corresponde a nunca e cinco (5) a sempre. Essa escala está apresentada no Anexo I.

\subsubsection{Motivação para o Treinamento}

O construto motivação para o treinamento foi mensurado pela escala produzida por Lacerda (2002), intitulada de escala de valor instrumental do treinamento, e por meio da inserção no questionário de pesquisa de um item de avaliação para o fator expectância, também foi possível a mensuração da força motivacional para o treinamento, conforme proposto por Pilati (2004). Esse tratamento da escala de Lacerda (2002), ao permitir o cálculo do índice de força motivacional, pode ser uma estratégia útil de análise e interpretação (ABBAD; LACERDA; PILATI, 2012). Essa escala e o item referente ao fator expectância estão apresentados no Anexo I.

O valor instrumental do treinamento é definido como a crença do indivíduo de que as novas habilidades por ele adquiridas em um curso the serão úteis para alcançar recompensas de várias naturezas (instrumentalidade), bem como a importância/valor que esse indivíduo atribui a cada uma dessas recompensas (valência) para a sua vida profissional (LACERDA E ABBAD, 2003). A escala produzida e validada por Lacerda (2002) apresenta 27 itens no total. Os 13 itens da escala de valência, estão associados a uma escala tipo Likert de cinco pontos, na qual 1 (um) corresponde a nada importante e 5 (cinco) a totalmente importante. Já a escala de instrumentalidade possui 14 itens e está associada na escala de tipo Likert de cinco pontos, com o valor 1 (um) correspondendo ao termo nada útil e o valor 5 (cinco) ao termo completamente útil. A estrutura unifatorial para a escala de valor instrumental do treinamento apresenta alto índice de consistência interna, calculado pelo Alfa de Cronbach, e itens com cargas fatoriais oscilando entre 0,32 e 0,73 . 
Os índices psicométricos do instrumento para a amostra utilizada em sua validação são apresentados na Tabela 11.

Tabela 11 - Índices Psicométricos da Escala de Valor Instrumental do Treinamento

\begin{tabular}{lrrrr}
\hline Nome do fator & Itens & Índice de Precisão & $\begin{array}{r}\text { Carga } \\
\text { Fatorial }\end{array}$ \\
\hline Valor Instrumental do Treinamento & 27 & 0,94 & 0,32 a 0,73 \\
\hline $\mathrm{KMO}=0,88$ & & & \\
\hline$\%$ da variância explicada $=37,62 \%$ & & & \\
\hline
\end{tabular}

Fonte: Abbad, Lacerda e Pilati (2012)

\subsection{Procedimento de Coleta de Dados}

Inicialmente foi solicitada autorização à área de recursos humanos do INCRA para a coleta de dados junto aos seus servidores. Esse requerimento foi realizado por intermédio do pesquisador e mestrando, que é servidor do Órgão, e de seu orientador (Apêndice I). O processo de autorização por parte do INCRA ocorreu em 15/09/2014 (Anexo II).

O questionário de pesquisa foi composto por duas escalas: a de suporte à aprendizagem e a de motivação para o treinamento. Ao final do instrumento, foram coletadas também as seguintes informações demográficas e funcionais: sexo, último grau de escolaridade concluído, idade, ocupação de cargo de chefia/supervisão, unidade de trabalho e tempo de serviço no Órgão. Todas as questões foram apresentadas em somente um questionário visando facilitar o preenchimento e a análise dos dados, sendo que na primeira parte do questionário constava o termo de consentimento para participação na pesquisa.

O objetivo do termo de consentimento era formalizar a informação de realização da pesquisa no Órgão, esclarecer quem eram os responsáveis pela pesquisa, revelar a temática abordada, explicar que a pesquisa era voluntária e, principalmente, perguntar se após os devidos esclarecimentos o servidor concordava em participar do estudo. Nesse documento o pesquisador também se colocou à disposição para esclarecer dúvidas e receber comentários por e-mail e também por telefone. Em razão do INCRA não possuir dados atualizados dos servidores que já haviam recebido treinamento pelo Órgão, foi necessário fazer um levantamento de participação em treinamentos junto aos servidores. Essa questão foi colocada junto ao termo de consentimento pela necessidade de prévia obtenção de concordância do servidor em participar da pesquisa, mesmo tendo ciência da possibilidade de que alguns servidores que já participaram de treinamentos poderiam decidir não participar da pesquisa. 
Outras questões relevantes foram descritas no termo de consentimento. Sustentou-se a importância da colaboração do servidor participando da pesquisa. Foi destacado que o tempo estimado para responder às questões era entre 5 e 10 minutos. E, por fim, foi esclarecido que os dados eram confidenciais e utilizados exclusivamente para fins acadêmicos.

O processo de coleta de dados, realizado por intermédio do questionário de pesquisa apresentado nessa Seção, foi feito de forma conjunta com a área de recursos humanos do Órgão e realizado via internet. Foi utilizado o aplicativo da surveymonkey para a produção e disponibilização do questionário para a coleta de dados online. Apesar dessa ferramenta permitir o envio do questionário produzido pelo gerenciador de e-mail integrado ao sistema e disponibilizar funcionalidades para o compartilhamento do questionário no Facebook, incorporação em página de sites e uso de pop-up, no presente estudo o compartilhamento do questionário foi feito exclusivamente por via do e-mail institucional do pesquisador. A mensagem que continha o link do questionário foi enviada para o endereço de e-mail dos servidores que estava cadastrado no Sistema Integrado de Administração de Recursos Humanos (SIAPE) e que fora fornecido pela área de recursos humanos do Órgão. A decisão de uso do e-mail institucional visou dar maior credibilidade às mensagens enviadas. Além disso, havia a decisão prévia de priorizar o uso de mensagens que incluíssem o nome dos destinatários no corpo da mensagem de e-mail, visando estabelecer um relacionamento individualizado com os servidores e possível melhoria nas taxas de retorno de questionários respondidos.

A operacionalização do envio de e-mails ocorreu seguindo um planejamento préestabelecido. Simultaneamente ao período de envio de e-mails adotou-se, conjuntamente com a área de recursos humanos do Órgão, uma estratégia de sensibilização de forma presencial dos servidores quanto ao conteúdo do e-mail que lhes fora enviado e da importância da pesquisa. O próprio pesquisador, ora sozinho, ora acompanhado por um integrante da equipe de recursos humanos do Órgão, visitou todas as unidades de trabalho do INCRA-Sede dando esclarecimentos sobre a pesquisa e respondendo a questionamentos de alguns servidores. A sensibilização presencial facilitou o entendimento da pesquisa e nesses encontros algumas dúvidas puderam ser sanadas, como, por exemplo, se os servidores com cargos comissionados poderiam participar do estudo e qual o local de lotação do pesquisador dentro do Órgão, pois alguns servidores não conheciam o pesquisador, que também é servidor da autarquia. 
Os três e-mails elaborados para a coleta de dados foram enviados para todos os servidores ocupantes de cargos de nível médio e superior lotados em Brasília, nas unidades do INCRA -Sede em setembro de 2014, o que perfazia um total de 391 servidores.

A amostra do estudo foi definida apenas após o término da coleta de dados, com o cruzamento dos servidores que aceitaram participar da pesquisa e enviaram os questionários respondidos em que declararam ter participado em treinamentos oferecidos pelo INCRA $(\mathrm{N}=161)$. No primeiro e-mail havia uma mensagem apresentando o pesquisador, contextualizando a pesquisa e pedindo a colaboração no preenchimento do questionário, assim como disponibilizando um link para instrumento online. Esse questionário foi enviado em 24/09/2014; já o segundo e-mail foi enviado posteriormente em 30/09/2014, funcionando principalmente como um lembrete para os interessados em responder a pesquisa. Por fim, o terceiro e-mail foi enviado no dia 14/10/2014, com três finalidades: a) agradecer aos servidores que já haviam aceitado participar da pesquisa; b) informar os servidores que esse era o último dia para a participação na pesquisa; e ainda c) esclarecer que se algum servidor houvesse respondido o questionário apenas parcialmente ele poderia respondê-lo completamente nessa data e ter sua opinião considerada na pesquisa. Como a coleta de dados foi realizada totalmente à distância, decidiu-se pela síntese das informações contidas no $e$ mail, pois o excesso de informações poderia desmotivar a resposta dos participantes. Diante dos procedimentos adotados para essa coleta de dados, os e-mails enviados aos servidores tiveram taxa de retorno de questionários respondidos de $41,18 \%$.

\subsection{Procedimento de Análise de Dados}

Nesta Seção serão apresentados os procedimentos de análise de dados, que foram realizados em duas fases para o alcance dos objetivos específicos propostos para esta dissertação. Na primeira, que teve a finalidade de adaptar e verificar evidências de validade estatística do instrumento de medida de suporte à aprendizagem elaborado por Coelho Jr. (2009), a avaliação da estrutura empírica foi realizada pela Análise dos Componentes Principais (ACP) e após a extração inicial dos fatores com base na ACP, foi executada a análise de fatoração dos eixos principais (PAF). A segunda fase tratou da mensuração do suporte à aprendizagem e da motivação para o treinamento e ainda, da investigação da relação entre as variáveis individuais (sexo, faixa etária e cargo de direção), o suporte à aprendizagem e a motivação para o treinamento por meio das análises de regressão stepwise. 
Antes da execução dos procedimentos exigidos para a fase 1 e 2 propostas, foi realizado o processo de exploração e tratamento dos dados por meio de análises estatísticas descritivas dos dados coletados (média, moda, mediana, desvio padrão e coeficiente de variação) e da identificação de missing values (valores faltantes) e de outliers (valores discrepantes). Efetuando o exame dos dados, o pesquisador passa a ter uma visão mais crítica de suas características e pode evitar erros de análises (HAIR et al., 2009).

Nenhum erro foi encontrado na amostra, porém 83 casos foram excluídos por conterem dados omissos. Ressalta-se que o tratamento em relação aos dados faltantes foi realizado pelo procedimento listwise, que adota como solução a exclusão dos casos que contenham dados omissos (HAIR et al., 2009) . Em relação à verificação de presença de outliers (casos atípicos), considerando a distância de Mahalanobis com a =0,001, dois outliers multivariados foram encontrados. Os casos extremos univariados foram identificados pela transformação das variáveis em escore padronizado $(Z)$, resultando em quatro outliers, seguindo o critério de $Z>3,29$ para $\mathrm{p} \leq 0,001$ (TABACHNICK; FIDELL, 2007). Optou-se pela exclusão dos casos extremos identificados, considerando que os casos designados como atípicos podem introduzir tendenciosidade no modelo que é ajustado aos dados (HAIR et al. 2009). Dessa forma, a amostra final contou com 155 casos, conforme já mencionado na Seção 3.2 do presente estudo. Após a exploração e tratamento dos dados, foram realizadas as análises estatísticas escolhidas para o alcance dos objetivos específicos desta pesquisa.

Para a fase 1, que objetivou adaptar e verificar evidências de validade estatística do instrumento de medida de suporte à aprendizagem elaborado por Coelho Jr. (2009), inicialmente realizou-se a avaliação da estrutura empírica pela Análise dos Componentes Principais (ACP), que possibilitou a verificação da fatorabilidade da matriz, a compreensão inicial do número de fatores a serem extraídos e a análise de multicolinearidade. Essas avaliações foram feitas considerando o tamanho da amostra, o valor das intercorrelações acima de 0,30, distribuição dos valores próprios, Scree Plot, teste de esferecidade de Bartlett $\mathrm{P}<0,001$, análise do Kaiser_meyer_Olkin $(\mathrm{KMO})$ e o critério de Análise Paralela de Horn (1965).

Após a extração inicial dos fatores com base na ACP, foi realizada a análise de fatoração dos eixos principais (PAF), com solução forçada com dois fatores. Devido ao compartilhamento de um item entre o primeiro e o segundo fator, significativas correlações entre o fator 1 e $2(0,795)$ e a falta de coerência teórica dos itens que compuseram cada fator 
foi realizada a extração final forçada em um único fator, também por meio da PAF, com tratamento listwise dos casos omissos, porém, por se tratar de uma solução unifatorial não foi aplicada a rotação de fatores. Assim como no trabalho de Coelho Jr. (2009) foram utilizados os seguintes critérios para a determinação fatorial da matriz: análise do Kaiser-Meyer-Olkin (KMO) próximos de 1 , teste de esferecidade de Bartlett, com $\mathrm{p}<0,001$; porcentagem da variância explicada (no mínimo 3\%), análise do Scree Plot, determinação de cargas e escores fatoriais $(>0,30)$, análise de correlação dos fatores, análise da consistência interna (Alpha de CronBach) e interpretabilidade das soluções.

Para a fase 2, a mensuração do suporte à aprendizagem foi realizada por meio da média dos valores obtidos por meio da escala de suporte à aprendizagem, validada na fase 1 e a motivação para o treinamento teve seu resultado calculado em função do produto da média de cada um dos seus três fatores, dando origem à força motivacional (valência versus instrumentalidade versus expectância), conforme sugerido por Lacerda e Abbad (2003) e Pilati (2004). A fim de incrementar os resultados, também foi realizado o cálculo da motivação para o treinamento por meio do valor instrumental do treinamento. Assim, na investigação da relação entre as variáveis individuais (sexo, faixa etária e cargo de direção), o suporte à aprendizagem e a motivação para o treinamento foram realizadas 2 análises de regressão stepwise. A primeira foi executada tendo como variável critério a força motivacional, e, posteriormente, para fim de comparação dos resultados obtidos, a segunda foi produzida tendo como variável critério o valor instrumental do treinamento (composta pelo produto da valência pela instrumentalidade). A opção pelo uso da regressão stepwise ocorreu por essa técnica ser útil para eliminar variáveis supérfluas da equação de regressão (TABACHNICK, FIDELL, 2007) e devido ao êxito da regressão múltipla nas pesquisas sobre aprendizagem (ABBAD, 1999).

Em cada uma das duas regressões produzidas, foram mantidas as variáveis antecedentes suporte à aprendizagem, sexo, faixa etária e cargo de direção. Em relação às três variáveis individuais utilizadas, duas variáveis são originalmente dicotômicas, sexo $(0=$ feminino e $1=$ masculino) e cargo de direção (ocupa cargo de direção: $0=\operatorname{sim}$ e 1 = não). A terceira variável foi transformada em variável dicotômica, faixa etária $(0=$ até 30 anos e $1=$ superior a 30 anos) sendo formada pelo conteúdo em comum expressado pelos participantes da pesquisa em relação à variável idade, conforme questionário de pesquisa apresentado no Anexo I. Apesar desse questionário ter coletado outras informações, optou-se por trabalhar apenas com as 
variáveis demográficas relacionadas a idade (faixa etária) e ao sexo, por serem as duas variáveis dessa categoria que mais aparecem em pesquisas de TD\&E (COLQUITT; LEPINE; NOE, 2000) e com a variável profissional cargo de direção, devido ao interesse em se investigarem possíveis diferenças no grau de motivação para o treinamento entre os indivíduos que ocupam e os que não ocupam cargo de direção.

Os procedimentos de análise dos pressupostos da regressão múltipla foram seguidos. Dessa forma, foram verificados o atendimento aos pressupostos da homogeneidade de variâncias (homocedasticidade), a linearidade, a normalidade, a multicolinearidade e a singularidade (TABACHNICK; FIDELL, 2007) para as regressões realizadas. Primeiramente a homocedasticidade e a linearidade foram analisadas pelos resíduos da regressão múltipla (HAIR et al., 2009). O pressuposto de normalidade foi verificado pelo cálculo do índice de assimetria da curva da função de distribuição de frequências e o índice de curtose (grau de achatamento curva), sendo que os resultados apresentaram índice de assimetria entre 1 e -1 para todas as variáveis analisadas. Quando a distribuição de uma variável é normal, os valores de assimetria e curtose são iguais a zero, porém valores de assimetria entre -1 e 1 são aceitáveis (TABACHNICK; FIDELL, 2007). Essas autoras afirmam que, apesar da normalidade não ser sempre requerida para as análises estatísticas, variáveis distribuídas de forma normal usualmente apresentam melhor solução. E, por fim, para a identificação de multicolinearidade e singularidade foi realizada a análise da correlação entre as variáveis de cada análise de regressão realizada e foi calculado o Fator de Inflação de Variância (VIF). O VIF foi igual a 1 nos dois modelos de regressão desenvolvidos, o que significa que a tolerância foi igual a 1 e assim não foi encontrada multicolinearidade nas análises de regressão analisadas (HAIR et al., 2009) . Em suma, nenhum pressuposto de regressão múltipla foi violado. A seguir, são descritos os resultados e discussões das análises realizadas. 


\section{RESULTADOS E DISCUSSÃO}

O objetivo geral desse trabalho foi testar um modelo que investiga o relacionamento entre as variáveis sexo, faixa etária e cargo de direção, o suporte à aprendizagem e a motivação para o treinamento no âmbito do INCRA. Neste Capítulo serão apresentados e discutidos os resultados obtidos a partir das duas fases executadas para o alcance dos objetivos específicos propostos. A primeira fase teve a finalidade de adaptar e verificar evidências de validade estatística do instrumento de medida de suporte à aprendizagem elaborado por Coelho Jr. (2009) e a segunda fase tratou da mensuração do suporte à aprendizagem e da motivação para o treinamento e ainda, da investigação da relação entre as variáveis individuais (sexo, faixa etária e cargo de direção), o suporte à aprendizagem e a motivação para o treinamento por meio de análises de regressão stepwise, conforme relatado na Seção 3.5 desta dissertação.

\subsection{Fase 1: Validação Estatística da Escala de Suporte à Aprendizagem}

Antes da utilização de uma técnica mais complexa de análise quantitativa o primeiro passo recomendado é o exame dos dados (HAIR et al., 2009). Nessa dissertação, no processo de identificação e tratamento dos casos extremos foram encontrados dois outliers multivariados (Mahalanobis com a $=0,001)$ e quatro outliers univariados $(Z>3,29$ para $p$ $\leq 0,001)$. Os casos extremos foram eliminados do banco de dados e as análises foram realizadas apenas com os casos restantes (FIELD, 2009). O procedimento de eliminação desses seis casos extremos não provocou perda significativa de dados a ponto de inviabilizar a realização das análises estatísticas propostas. Após estes processos, a amostra final contou com 155 casos e dessa forma, segundo Field (2009) não houve violação quanto ao tamanho mínimo da amostra necessária para a análise de fatores, conforme relatado na Seção 3.5.

Em seguida foram feitas análises estatísticas mais específicas, a fim de realizar a validação da escala de suporte à aprendizagem. 
A Tabela 12 apresenta os resultados obtidos pela Análise dos Componentes Principais (ACP), que foram considerados para a determinação do número de fatores a serem extraídos pela análise de fatoração dos eixos principais (PAF).

Tabela 12 - Resultados da Análise dos Componentes Principais para Cálculo do Número de Fatores Banco de Dados sem outliers

$\mathrm{KMO}=0,96 \quad$ Determinante da matriz de correlação: 1.821E-014

Variância Total Explicada: 60,15

Barthett's Test of Sphericity: 4487,18 $\quad \mathrm{p}<0,001$

Fonte: Dados da Pesquisa

Conforme apresentado na Tabela 12, o valor de KMO obtido foi acima de 0,90 e o teste de esfericidade de Barthett foi significativo. Já o determinante da matriz de correlação foi de $1.821 \mathrm{E}-01(0,1821)$, ou seja, obteve valor maior que 0,0001 , sendo apropriada a sua fatorização. Segundo Field (2009) valores menores que 0,00001 podem indicar a presença de multicolinearidade.

A solução fatorial obtida apontou que a variância total explicada na análise dos componentes principais foi de 60,15\%. O Coeficiente Alfa de Cronbach obtido para a amostra foi de 0,97. De acordo com os critérios de distribuição dos valores próprios superiores a 1 , observando o critério de percentagem mínima de 3\% de explicação para os fatores extraídos e considerando a análise gráfica por meio do scree Plot houve indicação para a extração de até 2 fatores.

A Figura 4 apresenta o scree Plot do banco de dados utilizado.

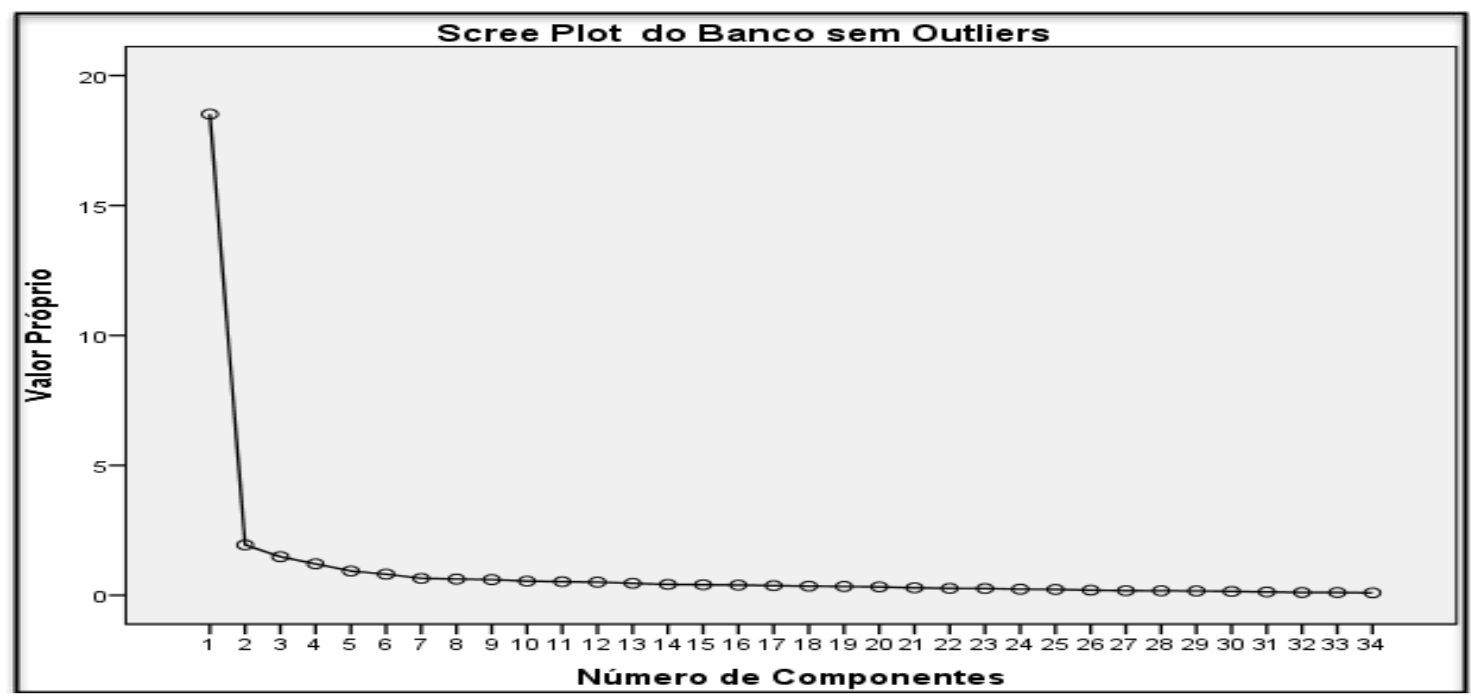

Figura 4 - Scree plot da matriz de dados da Escala de Suporte à Aprendizagem Fonte: Dados da Pesquisa 
Segundo o critério de Análise Paralela de Horn (1965) foram sugeridos dois fatores para serem extraídos na amostra analisada, comparando os valores próprios da matriz de correlação dos dados aleatórios com os da matriz empírica calculada pela análise dos componentes principais, retendo apenas os fatores que apresentaram valores próprios empíricos maiores que os valores próprios aleatórios. A Tabela 13 sintetiza os valores próprios empíricos e aleatórios obtidos para a escala de suporte à aprendizagem.

Tabela 13 - Eigenvalues Empíricos e Aleatórios dos Componentes da Amostras

\begin{tabular}{l|l|l|l|l}
\hline \multirow{2}{*}{ Bando de Dados } & \multirow{4}{*}{ Componentes } \\
\cline { 3 - 5 } & Eigenvalues & 1 & 2 & 3 \\
\hline \multirow{2}{*}{$\begin{array}{l}\text { Sem a presença de } \\
\text { outliers }\end{array}$} & Aleatório & 2,010 & 1,869 & 1,762 \\
\cline { 2 - 5 } & Empírico & 18,513 & 1,937 & 1,485 \\
\hline
\end{tabular}

Fonte: Dados da Pesquisa

Os dados da Tabela 13 apontam que os eigenvalues empíricos foram maiores que os eigenvalues aleatórios apenas até o componente 2, o que sugere a extração de dois fatores para o suporte à aprendizagem considerando a amostra utilizada. Dessa forma, foi verificada a sugestão de extração de dois fatores para o suporte à aprendizagem.

Após a determinação do número de fatores a serem extraídos, procedeu-se a análise de fatoração dos eixos principais (PAF) com o procedimento de rotação oblíqua e tratamento listewise para os dados omissos, forçando-se a solução com dois fatores. A PAF com rotação oblíqua é recomendada para situações em que haja indícios de que os fatores possam estar correlacionados (FIELD, 2009). Assim, como no estudo de Coelho Jr. (2009) os fatores 1 e 2 da escala de Suporte à Aprendizagem possuíam correlação, esse procedimento foi selecionado para a análise dos dados.

O primeiro fator explicou $54,45 \%$ da variância das respostas obtidas e o segundo fator explicou 5,70\%. Nota-se que o primeiro fator explicou quase dez vezes mais das variâncias das respostas dos participantes aos itens da escala em relação ao segundo fator, indicando a possibilidade de uma tendência a uni-dimensionalidade. Foi obtida uma correlação de alta magnitude entre o fator 1 e $2(r=0,795)$ e a disposição dos itens entre os fatores mostrou falta de coerência teórica dos itens que compuseram cada fator indicando a necessidade de uma estrutura empírica mais reduzida de suporte à aprendizagem, formada por apenas um fator, buscando alcançar uma estrutura parcimoniosa e coerente teoricamente. . 
A extração final forçada em um único fator, também foi realizada por meio da PAF, com tratamento listwise dos casos omissos, porém, por se tratar de uma solução unifatorial não foi aplicada a rotação de fatores. Esse teste encontrou-se uma estrutura empírica mais parcimoniosa, sendo composta por 34 itens (nenhum item foi retirado). O fator explicou $54,45 \%$ da variância total das respostas dos participantes ao instrumento, tem valor próprio de 18,51 e as cargas fatoriais oscilaram de 0,46 a 0,83 . A estrutura unifatorial apresenta um alfa de Cronbach $(0,97)$ que atesta sua consistência interna e também houve adesão da escala aos conceitos teóricos que a embasaram, sendo de uma forma geral considerada a estrutura mais satisfatória obtida. A Tabela 14 apresenta as cargas fatoriais, comunalidades $\left(\mathrm{h}^{2}\right)$, a média e o desvio padrão de cada item que constitui essa solução unifatorial.

Tabela 14 - Itens, Carga Fatorial, H2, Média e Desvio Padrão do Fator Suporte à Aprendizagem

\begin{tabular}{|c|c|c|c|c|}
\hline Descrição das variáveis & $\begin{array}{l}\text { Carga } \\
\text { Fatorial }\end{array}$ & $\mathrm{H}^{2}$ & Média & $\begin{array}{l}\text { Desvio } \\
\text { Padrão }\end{array}$ \\
\hline $\begin{array}{l}\text { Meu chefe/superior imediato assume comigo os } \\
\text { riscos de tentar novas formas de realizar o trabalho. }\end{array}$ & 0,830 & 0,689 & 3,49 & 1,17 \\
\hline $\begin{array}{l}\text { Meu chefe/superior imediato estimula o uso das } \\
\text { minhas novas habilidades e conhecimentos no } \\
\text { trabalho. }\end{array}$ & 0,823 & 0,677 & 3,57 & 1,15 \\
\hline $\begin{array}{l}\text { Meu chefe/superior imediato me incentiva a propor } \\
\text { mudanças em função do que aprendi em } \\
\text { treinamentos. }\end{array}$ & 0,819 & 0,670 & 3,21 & 1,13 \\
\hline $\begin{array}{l}\text { No meu setor de trabalho cada membro é } \\
\text { incentivado a expor o que pensa. }\end{array}$ & 0,811 & 0,657 & 3,47 & 1,16 \\
\hline $\begin{array}{l}\text { Meu chefe/superior imediato me encoraja a aplicar } \\
\text { novas habilidades e conhecimentos. }\end{array}$ & 0,809 & 0,654 & 3,48 & 1,16 \\
\hline $\begin{array}{l}\text { Meu chefe/superior imediato valoriza minhas } \\
\text { sugestões de mudança. }\end{array}$ & 0,800 & 0,641 & 3,65 & 1,03 \\
\hline $\begin{array}{l}\text { No meu setor de trabalho há incentivo à busca por } \\
\text { novas aprendizagens. }\end{array}$ & 0,795 & 0,631 & 3,26 & 1,15 \\
\hline $\begin{array}{l}\text { No meu setor de trabalho as tentativas de aplicação } \\
\text { de novas habilidades e conhecimentos são elogiadas. }\end{array}$ & 0,794 & 0,631 & 3,25 & 1,08 \\
\hline $\begin{array}{l}\text { Meu chefe/superior imediato estabelece }(\mathrm{m}) \text { objetivos } \\
\text { de trabalho que me encorajam a aplicar novas } \\
\text { habilidades e conhecimentos. }\end{array}$ & 0,787 & 0,619 & 3,19 & 1,09 \\
\hline $\begin{array}{l}\text { Meu chefe/superior imediato me elogia quando } \\
\text { aplico novas habilidades e conhecimentos. }\end{array}$ & 0,785 & 0,617 & 3,44 & 1,22 \\
\hline $\begin{array}{l}\text { No meu setor de trabalho novas ideias são } \\
\text { valorizadas. }\end{array}$ & 0,783 & 0,613 & 3,59 & 1,00 \\
\hline $\begin{array}{l}\text { Meus colegas/pares de trabalho apoiam minhas } \\
\text { tentativas de buscar novas aprendizagens no } \\
\text { trabalho. }\end{array}$ & 0,782 & 0,611 & 3,46 & 1,06 \\
\hline $\begin{array}{l}\text { Meus colegas/pares de trabalho me estimulam a } \\
\text { buscar novas habilidades e conhecimentos voltados } \\
\text { ao trabalho. }\end{array}$ & 0,778 & 0,606 & 3,17 & 1,09 \\
\hline $\begin{array}{l}\text { Meu chefe/superior imediato me estimula a enfrentar } \\
\text { desafios no trabalho. }\end{array}$ & 0,771 & 0,594 & 3,48 & 1,13 \\
\hline $\begin{array}{l}\text { Meus colegas/pares de trabalho apoiam as tentativas } \\
\text { que faço de utilizar no trabalho novas habilidades } \\
\text { que aprendi em treinamentos. }\end{array}$ & 0,761 & 0,579 & 3,41 & 1,04 \\
\hline
\end{tabular}


cont. Tabela 14- Itens, Carga Fatorial, H2, Média e Desvio Padrão do Fator Suporte à

\section{Aprendizagem}

\begin{tabular}{|c|c|c|c|c|}
\hline $\begin{array}{l}\text { Meu chefe/superior imediato remove dificuldades e } \\
\text { obstáculos à aplicação de minhas novas habilidades } \\
\text { e conhecimentos no trabalho. }\end{array}$ & 0,757 & 0,574 & 3,32 & 1,07 \\
\hline $\begin{array}{l}\text { No meu setor de trabalho há abertura a críticas } \\
\text { quando alguém aplica novas habilidades e } \\
\text { conhecimentos. }\end{array}$ & 0,744 & 0,553 & 3,56 & 1,05 \\
\hline $\begin{array}{l}\text { Meus colegas/pares de trabalho me dão orientações } \\
\text { quando tenho dificuldades para aplicar novas } \\
\text { habilidades e conhecimentos. }\end{array}$ & 0,744 & 0,553 & 3,59 & 1,04 \\
\hline $\begin{array}{l}\text { No meu setor de trabalho há compartilhamento de } \\
\text { informações sobre novas habilidades e } \\
\text { conhecimentos. }\end{array}$ & 0,727 & 0,529 & 3,57 & 0,99 \\
\hline $\begin{array}{l}\text { No meu setor de trabalho há autonomia para } \\
\text { organizar o trabalho. }\end{array}$ & 0,722 & 0,521 & 3,86 & 0,94 \\
\hline $\begin{array}{l}\text { No meu setor de trabalho há aceitação dos riscos } \\
\text { associados à aplicação de novas habilidades e } \\
\text { conhecimentos. }\end{array}$ & 0,721 & 0,519 & 3,17 & 0,91 \\
\hline $\begin{array}{l}\text { Meus colegas/pares de trabalho me incentivam a } \\
\text { propor novas ideias para a execução de tarefas. }\end{array}$ & 0,719 & 0,517 & 3,19 & 1,04 \\
\hline $\begin{array}{l}\text { Meu chefe/superior imediato me dá liberdade para } \\
\text { decidir sobre como desenvolver minhas tarefas. }\end{array}$ & 0,711 & 0,505 & 4,03 & 0,94 \\
\hline $\begin{array}{l}\text { Meu chefe/superior imediato está disponível para } \\
\text { tirar minhas dúvidas sobre o uso de novas } \\
\text { habilidades e conhecimentos no trabalho. }\end{array}$ & 0,709 & 0,503 & 3,78 & 1,20 \\
\hline $\begin{array}{l}\text { Meu chefe/superior imediato leva em conta minhas } \\
\text { ideias quando diferente das dele. }\end{array}$ & 0,698 & 0,487 & 3,44 & 0,99 \\
\hline $\begin{array}{l}\text { Meus colegas/pares de trabalho me elogiam quando } \\
\text { aplico minhas novas habilidades e conhecimentos. }\end{array}$ & 0,681 & 0,463 & 3,26 & 0,96 \\
\hline $\begin{array}{l}\text { No meu setor de trabalho há autonomia para } \\
\text { questionar as ordens dadas pelo chefe/superior. }\end{array}$ & 0,642 & 0,412 & 3,51 & 1,04 \\
\hline $\begin{array}{l}\text { No meu setor de trabalho as tarefas facilitam a } \\
\text { aplicação de novas habilidades e conhecimentos. }\end{array}$ & 0,638 & 0,408 & 3,29 & 0,88 \\
\hline $\begin{array}{l}\text { Meus colegas/pares de trabalho sentem-se seguros } \\
\text { quando aplico novas habilidades e conhecimentos no } \\
\text { trabalho. }\end{array}$ & 0,638 & 0,407 & 3,49 & 1,16 \\
\hline $\begin{array}{l}\text { No meu setor de trabalho a distribuição das tarefas } \\
\text { facilita a participação em treinamentos. }\end{array}$ & 0,634 & 0,402 & 3,19 & 1,08 \\
\hline $\begin{array}{l}\text { No meu setor de trabalho há tempo destinado para a } \\
\text { busca de novas formas de executar o trabalho. }\end{array}$ & 0,624 & 0,398 & 2,88 & 1,02 \\
\hline $\begin{array}{l}\text { No meu setor de trabalho há tolerância a erros } \\
\text { quando se tenta aplicar novas habilidades e } \\
\text { conhecimentos. }\end{array}$ & 0,590 & 0,348 & 3,63 & 0,95 \\
\hline No meu setor de trabalho há respeito mútuo. & 0,524 & 0,275 & 4,24 & 0,83 \\
\hline $\begin{array}{l}\text { No meu setor de trabalho há autonomia para agir } \\
\text { sem consultar o chefe/superior. }\end{array}$ & 0,462 & 0,213 & 2,89 & 1,08 \\
\hline Casos válidos & 155 & \multicolumn{3}{|c|}{$\mathrm{KMO}=0,96$} \\
\hline Número de variáveis & 34 & & & \\
\hline Variância explicada & $54,45 \%$ & & & \\
\hline Valor Próprio (Eigenvalue) & 18,51 & & & \\
\hline Consistência interna (alfa de Cronbach) & 0,97 & & & \\
\hline
\end{tabular}

Fonte: Dados da Pesquisa 
De forma geral, esses resultados convergem com o estudo desenvolvido por Coelho Jr. (2009). Esse autor também obteve em sua validação da solução unifatorial de Suporte à Aprendizagem índices psicométricos bastante aceitáveis, com cargas fatoriais que oscilaram entre 0,60 e 0,98 e com explicação de $64,78 \%$ da variância total das respostas dos participantes ao instrumento.

Todavia, diferentemente do presente estudo, Coelho Jr. (2009) obteve ainda uma estrutura empírica bifatorial coerente teoricamente e com índices psicométricos aceitáveis e bastante satisfatórios, que apesar das altas correlações encontradas entre os Fatores 1 e 2, foi amplamente recomendada. De acordo com esse autor, sugere-se o uso da escala bifatorial de suporte à aprendizagem para situações em que se objetive diferenciar o suporte percebido pelo indivíduo como mais informalizado, que é fornecido pelos colegas e pares, ou o suporte percebido como mais formalizado, provido pelas chefias e unidades de trabalho. Já a escala unifatorial de Suporte à Aprendizagem é sugerida para situações em que se objetive a realização de um diagnóstico preliminar acerca das condições ambientais de suporte à aprendizagem informal existentes no ambiente de trabalho. Assim, como no presente estudo foi validada a escala unifatorial de Percepção de Suporte à Aprendizagem, recomenda-se seu uso para diagnóstico preliminar acerca das condições ambientais de suporte à aprendizagem no ambiente de trabalho. A investigação de características de suporte psicossocial possibilita a análise da influência do ambiente organizacional quanto ao estímulo à aprendizagem dos indivíduos, principalmente no que concerne aos fatores facilitadores de aquisição e da aplicação de novas habilidades e conhecimentos no trabalho (COELHO JR.; ABBAD; TODESCHINI, 2005).

\subsection{Fase 2: Mensuração das Variáveis Utilizadas e Testagem do Modelo de Investigação}

De modo geral, os pesquisadores realizam a análise descritiva dos dados, para posteriormente efetuarem outras análises estatisticas para investigar as relações entre as variáveis (Sampieri; Collado; Lucio, 1991). 
Dessa forma, apresentam-se na Tabela 15 os resultados obtidos com as análises descritivas realizadas, que incluem a média, a moda, a mediana, o desvio padrão e o coeficiente de variação das variáveis: suporte à aprendizagem, valência, instrumentalidade, expectância, força motivacional e valor instrumental do treinamento.

Tabela 15 - Análise Descritiva dos Dados

\begin{tabular}{llllll}
\hline Variáveis & Média & Moda & Mediana & $\begin{array}{l}\text { Desvio } \\
\text { Padrão }\end{array}$ & $\begin{array}{l}\text { Coeficiente } \\
\text { de Variação }\end{array}$ \\
\hline Suporte à Aprendizagem & 3,44 & 4,26 & 3,56 & 0,77 & 0,22 \\
\hline Valência & 3,86 & 4,08 & 3,92 & 0,58 & 0,15 \\
\hline Instrumentalidade & 3,39 & 3,71 & 3,43 & 0,75 & 0,22 \\
\hline Expectância & 3,21 & 4,00 & 3,00 & 0,98 & 0,30 \\
\hline Força Motivacional & 44,48 & 33,23 & 42,35 & 22,76 & 0,51 \\
\hline Valor Instrumental do Treinamento & 13,26 & 9,49 & 13,19 & 4,10 & 0,31 \\
\hline
\end{tabular}

Fonte: Dados da Pesquisa

A análise descritiva mostrou dentre outros indicadores a média e o desvio-padrão das seguintes variáveis: a) suporte à aprendizagem (Média $=3,44$; Desvio-Padrão=0,77); b) Valência (Média =3,86; Desvio-Padrão=0,58); c) a instrumentalidade (Média =3,39; DesvioPadrão=0,75); d) Expectância (Média =3,21; Desvio-Padrão=0,98); e) Força Motivacional (Média $=44,80$; Desvio-Padrão=22,76); e o f) Valor Instrumental do Treinamento (Média=13,23; Desvio-Padrão=4,10).

Nota-se que em relação aos três fatores componentes da força motivacional, a valência apresentou a maior média $(3,86)$. Em relação à dispersão dos dados, a força motivacional foi a variável que apresentou maior desvio padrão $(22,76)$, seguida pelo valor instrumental do treinamento $(4,10)$. Essa alta dispersão dos dados em torno da média da força motivacional também foi encontrada por Alves-Filho (2012), em seu estudo sobre a motivação para o trabalho dos profissionais de saúde $(20,66)$.

Conforme mencionado, a motivação para o treinamento foi calculada em função do produto da média de cada um dos seus três fatores dando origem a força motivacional e também, a fim de incrementar os resultados, foi realizado o cálculo da motivação para o treinamento por meio do valor instrumental do treinamento. Após a análise descritiva dos dados foram realizadas as análises de regressão propostas. 
A Tabela 16 apresenta os resultados da aplicação das análises de regressão stepwise para a realização do teste empírico das relações entre as variáveis individuais (sexo, faixa etária e cargo de direção), o suporte à aprendizagem e a motivação para o treinamento.

Tabela 16 - Resultado das Análises de Regressão Múltipla Stepwise

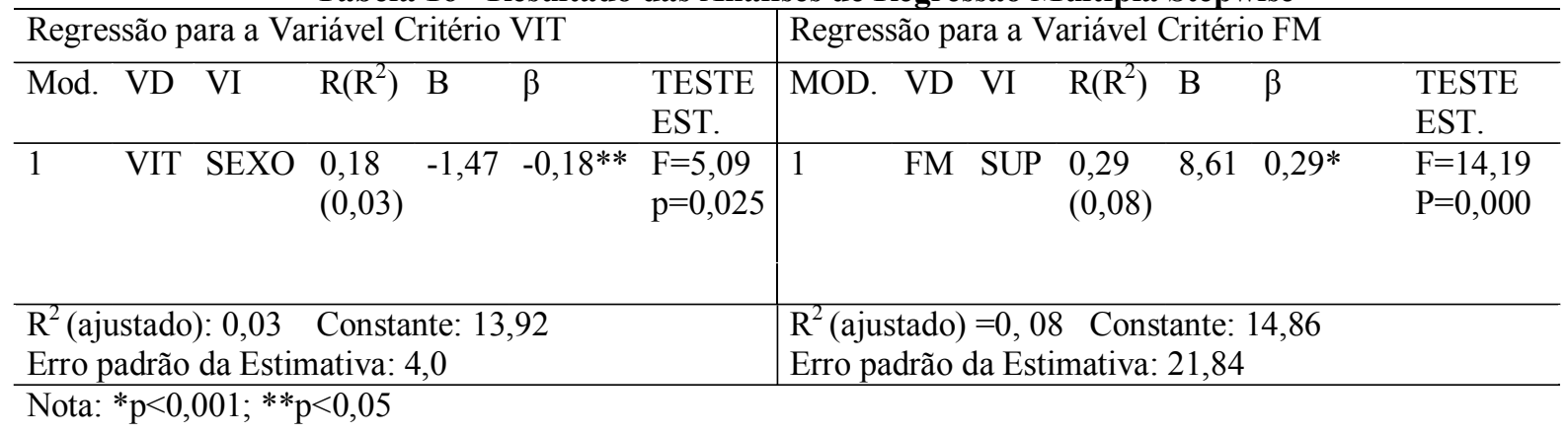

Os resultados apresentados pela análise de regressão realizada para a variável critério valor instrumental do treinamento mostram que apenas a variável antecedente sexo $(\beta=-0,18)$ entrou no modelo de regressão, explicando $3 \%$ da variância da variável critério $\left(R^{2}=0,03\right)$. Com base na Tabela 16, infere-se que os indivíduos do sexo feminino possuíam maiores escores de valor instrumental do treinamento, do que indivíduos do sexo masculino. $\mathrm{O}$ resultado da ANOVA indicou a significância do modelo $(\mathrm{F}=5,09$ e $\mathrm{P}<0,05)$.

Já os resultados produzidos pela análise de regressão que teve a força motivacional como variável critério, diferem dos resultados obtidos com a regressão realizada para a variável valor instrumental, pois, de acordo com a Tabela 16, apenas a variável suporte à aprendizagem $(\beta=0,29)$ contribuiu significativamente para a explicação da força motivacional. As variáveis sexo, faixa etária e cargo de direção não apresentaram de maneira significativa melhoria do poder de previsão da equação de regressão e não foram introduzidas no modelo.

A variável antecedente suporte à aprendizagem entrou no modelo de regressão, explicando $8 \%$ da variância da variável critério força motivacional $\left(\mathrm{R}^{2}=0,08\right)$. O coeficiente de regressão para o suporte à aprendizagem é positivo $(B=8,61)$, o que indica que os indivíduos que possuíam percepção mais favorável de suporte à aprendizagem foram os que apresentaram maior força motivacional. Esse modelo também obteve resultados significativos, conforme resultados da $\operatorname{ANOVA}(\mathrm{F}=14,19$ e $\mathrm{P}<0,001)$. O erro padrão foi de 21,84 .

Esses dados empíricos fornecem as informações sobre o teste de hipótese do modelo de pesquisa desta dissertação. Apenas quando a motivação para o treinamento foi mensurada 
pela força motivacional é que a hipótese 1 foi aceita. Essa hipótese afirmava que indivíduos que possuem percepção mais favorável de suporte à aprendizagem apresentariam maior motivação para o treinamento em relação àqueles que tem percepção menos favorável de suporte à aprendizagem. A hipótese 2 afirmava que indivíduos do sexo feminino apresentariam maior motivação para o treinamento em relação aos indivíduos do sexo masculino e foi aceita apenas quando a motivação para o treinamento foi mensurada pelo valor instrumental do treinamento. Porém, os baixos valores apresentados por $\mathrm{R}^{2}$ pelos modelos obtidos pela regressão stepwise produzidas para a força motivacional $\left(\mathrm{R}^{2}=0,08\right)$ e para o valor instrumental do trabalho $\left(\mathrm{R}^{2}=0,03\right)$, indicam a existência de outras variáveis antecedentes, que podem explicar grande parcela da variabilidade dessas variáveis e que não foram inseridas nesse estudo.

Já as hipóteses 3 e 4, que diziam respectivamente que, indivíduos de menor faixa etária apresentarão maior motivação para o treinamento em relação à indivíduos de faixa etária superior e que os servidores que não ocupam cargo de direção apresentariam maior motivação para o treinamento em relação aos ocupantes de cargo de direção foram ambas refutadas. Essas variáveis (faixa etária e cargo de direção) não apresentaram de maneira significativa melhoria do poder de previsão da equação de nenhuma das duas análises de regressão realizadas.

O erro padrão de estimativa obtido foi elevado para a equação produzida para a motivação para o treinamento, considerando como variável critério a força motivacional $(21,84)$ e também o valor instrumental do treinamento $(4,0)$. Esse indicador representa a estimativa do desvio-padrão dos valores reais dependentes em torno da reta de regressão, ou seja, mensura a variação em torno da reta de regressão (HAIR et al., 2009). Resultado semelhante também já havia sido encontrado em situações de aprendizagem informal. Em seu estudo Ribeiro (2005) teve como variáveis antecedentes gênero, idade, tempo de serviço no cargo e na organização, formação acadêmica, ramo de atuação da organização, área de trabalho, tipo de cargo e natureza da organização e como variável critério a motivação através da expectância (calculada por meio da força motivacional). Essa autora encontrou que apenas três dessas variáveis foram preditoras da força motivacional: graduação em pedagogia; graduação em saúde e área de atuação em RH. O erro padrão obtido em seu modelo de regressão foi de 198,20. Assim, esses resultados não devem ser generalizados, há necessidades de outros estudos. 
Apesar dos resultados não muito promissores encontrados neste estudo, a literatura relata a importância das variáveis individuais e situacionais em relação à motivação para o treinamento. De acordo com Beier e Kanfer (2010), a aplicação da teoria da expectância em contextos de treinamentos aponta duas grandes categorias de variáveis que influenciam as decisões de valência, instrumentalidade e expectância: as características do treinando e o contexto organizacional.

Em sua revisão sobre a motivação para o treinamento, Colquitt, Lepine e Noe (2000) identificaram do grupo das características individuais da clientela diversas variáveis que são preditoras da motivação para o treinamento: lócus de controle, conscienciosidade, ansiedade, envolvimento com o trabalho, comprometimento organizacional, planejamento de carreira, exploração de carreira, auto-eficácia, valência e idade. Entretanto, nem sempre os resultados de pesquisas sobre essas variáveis, suas correlatas e outras variáveis dessas categorias são promissores. A literatura aponta que indivíduos do sexo feminino apresentam maior motivação para o treinamento que indivíduos do sexo masculino (THARENOU, 2001). Há resultados de pesquisas que relatam que a variável gênero não foi preditiva da motivação através da expectância (RIBEIRO, 2005). E no presente estudo, os resultados indicaram que apesar da variável sexo não ter sido preditiva da força motivacional, os indivíduos do sexo feminino, possuíam maiores escores de valor instrumental do treinamento do que os indivíduos do sexo masculino.

Já em relação às características situacionais, a literatura mostra que o suporte do chefe, suporte dos pares e o clima para a transferência foram identificados como preditores da motivação para o treinamento (COLQUITT; LEPINE; NOE, 2000). Nesta dissertação foi identificado que os indivíduos que possuem percepção mais favorável de suporte à aprendizagem apresentaram maior força motivacional para o treinamento em relação àqueles com percepção menos favorável de suporte à aprendizagem. Dessa forma, os resultados desta pesquisa, estão em consonância com outros achados de pesquisas sobre variáveis correlatas. Segundo Tharenou (2001) o comportamento do supervisor de acordo com a percepção dos subordinados está realacionada à participação em treinamento e desenvolvimento. Facteau et al. (1995) também identificaram em sua pesquisa que aprendizes que perceberam um maior grau de apoio de seus superiores imediatos para o treinamento relataram maior motivação para participar e aprender com a formação. Também em relação ao suporte recebido pelos egressos dos treinamentos, os supervisores exercem mais influência do que os colegas de 
trabalho sobre a decisão do aprendiz sobre a implementação do que foi aprendido em treinamento (FOXON, 1993). A importância do apoio do supervisor comparado a outros aspectos do ambiente de trabalho talvez ocorra por ser uma variável mais proximal à participação dos empregados em ações de treinamento e desenvolvimento. De forma geral, a literatura sobre TD\&E ressalta que o contexto organizacional pode influenciar as variáveis motivacionais em relação ao treinamento (MATHIEU; MARTINEAU, 1997; FACTEAU et al., 1995; COLQUITT; LEPINE; NOE, 2000; NGUYEN; KIM, 2013; BORGESANDRADE; ZERBINI; ABBAD; MOURÃO, 2013). A seguir, apresentam-se as considerações finais sobre esse estudo. 


\section{CONSIDERAÇÕES FINAIS}

Neste Capítulo, são feitas breves considerações finais a respeito das principais conclusões, contribuições e limitações desta dissertação e será proposta uma agenda de pesquisa para futuros estudos.

Os objetivos estabelecidos para a realização dessa pesquisa foram alcançados. No que se refere à fase 1 do estudo, foi realizada a adaptação e encontrou-se evidências de validade estatística do instrumento de medida de suporte à aprendizagem elaborado por Coelho Jr. (2009). As análises realizadas para a amostra utilizada mostraram que os índices psicométricos encontrados foram satisfatórios. Recomenda-se o uso da escala unifatorial de suporte à aprendizagem validada neste estudo para situações de diagnóstico preliminar acerca das condições ambientais de suporte à aprendizagem no ambiente de trabalho, tendo por base as recomendações de Coelho Jr. (2009). A investigação de características de suporte psicossocial possibilita a análise da influência do ambiente organizacional quanto ao estímulo à aprendizagem dos indivíduos, principalmente no que concerne aos fatores facilitadores de aquisição e da aplicação de novas habilidades e conhecimentos no trabalho.

Diante dos resultados apresentados e da revisão efetuada, sugere-se para estudos futuros a construção e validação de outros instrumentos de pesquisa sobre variáveis de contexto. Algumas sugestões seriam a produção de outras medidas que incluam itens sobre o apoio à educação à distância e que tratem da construção e validação de novos instrumentos de avaliação de suporte $\square$ transferêná a que sej a mes peáfi cos e di nhados co mas car act eísticas dos programas de TD\&E.

Em relação à fase 2 do estudo, seu desenvolvimento tornou possível a testagem da relação entre as variáveis individuais (sexo, faixa etária e cargo de direção), o suporte à aprendizagem e a motivação para o treinamento, por meio do teste de hipóteses construídas a partir de evidências empíricas. Este estudo veio a apoiar os relatos empíricos de alguns que identificaram relações entre variáveis de contexto, variáveis demográficas e variáveis motivacionais. A principal contribuição deste estudo foi apontar a relação existente entre o suporte à aprendizagem e a força motivacional e, de forma complementar, a relação entre a variável sexo e a variável valor instrumental do treinamento. Todavia, o baixo valor explicado pelos modelos obtidos pela regressão stepwise produzidas para a força motivacional e para o valor instrumental do trabalho indicam a existência de outras variáveis antecedentes, 
que podem explicar grande parcela da variabilidade dessas variáveis e que não foram inseridas neste estudo.

Apesar da literatura em geral ser clara sobre a influência da motivação para o treinamento nos resultados de aprendizagem (NGUYEN; KIM, 2013, MENESES et al., 2006, ABBAD, 1999) um modelo adequado, que explique os antecedentes da motivação para o treinamento, ainda não foi construído (NGUYEN; KIM, 2013). De forma geral, os resultados apresentados por esta dissertação confirmam que essa ainda é uma relevante lacuna de pesquisa, pois em termos empíricos a construção de modelos que ajudam na compreensão da motivação para o treinamento é fundamental para contribuir com o aperfeiçoamento dos modelos de avaliação de efetividade dos treinamentos (MATHIEU; MARTINEAU, 1997; TANENBAUM; YUKL, 1992; PATRICK et al., 2011).

Acredita-se, também, que o resultado secundário produzido por este trabalho por meio da revisão nacional efetuada sobre a motivação para o treinamento constituiu um importante marco para a literatura nacional. Essa revisão teve como objetivo principal apresentar um panorama dos estudos nacionais sobre a motivação para o treinamento e, em função dos critérios de busca bibliográficos descritos na metodologia deste estudo, foram localizadas uma quantidade ínfima de artigos, três no total. De forma geral, os resultados revelaram que as pesquisas sobre a motivação para o treinamento são escassas e nem sempre encontram resultados promissores. Talvez esse fato se deva, pelo menos em parte, ao pouco interesse dos pesquisadores por essa linha de pesquisa. A literatura internacional já havia apontado que foi apenas há poucas décadas que se iniciaram as pesquisas sobre a motivação para o treinamento (COLQUITT; LEPINE; NOE, 2000).

Algumas implicações práticas partindo da ideia central de que as variáveis de contexto precisam ser estimuladoras da aprendizagem e não restritoras, podem ser apontadas. Uma oportunidade seria a adoção de cursos gerenciais, com conteúdos relativos $\square$ i mport ânáa do suporte gerencial e social $\square$ aprend zage me $\square$ transfer êria das c ompet ências aprendi das em TD\&E para o trabalho (BORGES-ANDRADE et al., 2013). Esses autores explicam que os gerentes são os principais responsáveis a respeito do apoio necessário à transferência de aprendizagem para o trabalho e às melhorias do desempenho individual e organizacional, porém, muitas vezes tais gestores não estão qualificados para fornecer o suporte adequado. Assim, realmente percebe-se que o investimento em aquisição de competências gerais 
relacionadas ao suporte à aprendizagem é fundamental para a efetividade das ações de TD\&E. Não há como ignorar o papel do gestor.

Outra implicação prática dessa pesquisa refere-se aos apontamentos realizados por Facteau et al. (1995) em relação a exemplos de incentivos que os gerentes precisam fornecer aos aprendizes. Segundo esses autores, os resultados de seu trabalho sugerem que os supervisores devem estimular e apoiar aos esforços de treinamento empregados pelos aprendizes, para que esses tenham maior motivação pré-treinamento e, para isso, fornecendo incentivos, tais como: oportunidades de usar as habilidades aprendidas no treinamento, feedbacks sobre tentativas de transferência de habilidades aprendidas e recompensas das efetivas transferências de habilidades para o trabalho.

Além da motivação pré-treinamento, segundo Foxon (1994) o nível de percepção de suporte do supervisor para utilização das habilidades no trabalho afeta a transferência do que foi aprendido em treinamento de modo bastante acentuado. Dessa forma, percebe-se que os resultados de pesquisas reforçam que o suporte é importante em várias fases dentro do processo de aprendizagem, o que mostra a importância das organizações e seus gestores adotarem práticas de incentivo as ações de TD\&E. Em relação a esses tipos de implicações práticas, Borges-Andrade et al. (2013) também são enfáticos sobre questões que podem restringir o alcance dos resultados esperados com os treinamentos, e afirmam que certas restrições situacionais do ambiente de trabalho devem ser extintas, tais como falta de apoio de chefes e colegas, tarefas incompatíveis, interferências, interrupções, pressões de tempo e conflito de papéis. Por outro lado, Carvalho-Silva (2008) identificou em seu estudo que, mesmo em contexto desfavorável, os indivíduos pesquisados relataram altos níveis de motivação para a aprendizagem.

De acordo com os resultados apresentados e discutidos, propõe-se a seguinte agenda de pesquisa para futuros estudos: (1) Sugere-se a produção de artigos de natureza teórica sobre a motivação para o treinamento, que tratem tanto de revisões, discussões, quanto de construções e proposições; (2) escolha de pluralismo metodológico para diferentes objetivos de pesquisa, ou seja, utilização combinada de várias técnicas de pesquisa. Por exemplo, poderia ser utilizada a técnica survey (baseando-se na percepção) com a aplicação dos instrumentos já produzidos e cruzando as respostas com os resultados de desempenho da organização, trabalhando em um nível mais macro para a verificação dos resultados obtidos com o treinamento. E, ainda, poderia ser feito o uso de pesquisas documentais utilizando múltiplos 
bancos de dados que permitissem dar maior atenção aos processos de motivação para o treinamento frente aos diferentes tipos de treinamentos, perpassando por distintos contextos históricos e características organizacionais e dos próprios treinamentos em si (conteúdo, instrutor, modalidade); (3) utilização de análises multiníveis para a melhor compreensão das relações entre as variáveis pertencentes a diferentes níveis organizacionais; (4) produção de novos estudos sobre a testagem da relação entre variáveis de contexto, individuais e variáveis motivacionais em relação ao treinamento; (5) produção/aperfeiçamento e validação de instrumentos para os construtos motivação para aprender, motivação para transferir, valor instrumental do treinamento e força motivacional para o treinamento; (6) construção e validação de instrumentos de pesquisa sobre variáveis de contexto; (7) desenvolvimento de estudos junto a empresas do terceiro setor, conjuntamente com estudos no setor público e privado para que possa haver comparação dos dados coletados.

De forma geral, este estudo também possui pelo menos cinco limitações. A primeira refere-se à seleção da amostra, que foi realizada por conveniência. Após a delimitação da população, a decisão sobre o tipo de amostra selecionada foi tomada conjuntamente com a organização. Como o Órgão não possuía a relação atualizada dos servidores que já haviam participado de ações de capacitação no INCRA foi inviabilizada a amostragem aleatória. Diante disso, a amostragem de pesquisa considerada a mais adequada para o estudo proposto foi a não probabilística por conveniência. Nessa modalidade, o pesquisador seleciona os elementos a que tem acesso, admitindo que eles possam de alguma maneira, representar a população (GIL, 1999). A segunda refere-se ao possível viés de resposta, pois os dados foram coletados de questionários autoaplicáveis, o que pode influenciar de forma indesejada os valores obtidos com as mensurações realizadas e as relações observadas entre as variáveis estudadas. A terceira refere-se à não inclusão de variáveis relativas às características do treinamento, seja como variáveis independentes ou variáveis moderadoras em relação ao estudo da motivação para o treinamento, dentre elas: finalidade da ação de TD\&E (ambientação, introdutório, formação, comportamental, estratégico, gerencial, técnico ou operacional), tipo de ação (aperfeiçoamento ou educação formal), modalidade da ação (à distância, presencial ou semipresencial) e tipo de Instituição promotora da ação (escola de governo, próprio órgão, outros órgãos públicos ou instituição privada). A quarta refere-se ao uso de análise fatorial exploratória para a verificação de evidências de validade estatística do instrumento de medida de suporte à aprendizagem elaborado por Coelho Jr. (2009). A análise 
fatorial confirmatória não foi utilizada. E por fim, a quinta limitação refere-se à medida de mensuração adotada neste estudo para avaliar a força motivacional. A mensuração desse construto foi realizada por meio do cálculo do produto dos fatores valência e instrumentalidade por um item de avaliação sobre a expectância, conforme proposto por Pilati (2004). Todavia, sem ter a evidência empírica confirmada do fator expectância.

Por fim, espera-se que os resultados desta pesquisa sejam úteis para a área de estudo da motivação em contexto de treinamentos. Em especial para a linha de estudos que tem como principal abordagem propor e testar modelos compreensivos sobre como as características individuais e situacionais influenciam a motivação para o treinamento e o aprendizado (COLQUITT; LEPINE; NOE, 2000; PATRICK et al., 2011). A continuidade desse tipo de estudo é necessária considerando tanto o fato de que a literatura internacional aponta que essa linha de pesquisa ainda precisa de mais desenvolvimento (NGUYEN; KIM, 2013), quanto os achados que revelam que em âmbito nacional, as pesquisas sobre essa temática são escassas e nem sempre encontram resultados promissores. 


\section{REFERÊNCIAS}

ABBAD, G. S.; BORGES-ANDRADE, J. E. Aprendizagem humana em organizações de trabalho. In: ZANELLI, J. C.; BORGES-ANDRADE, J. E.; BASTOS, A. V. B. (Org.) Psicologia, Organizações e Trabalho no Brasil. Porto Alegre: Artmed, 2004, p.237-275.

ABBAD, G. S.; COELHO JR., F. A.; FREITAS, I. A.; PILATI, R. Medidas de suporte em avaliação de TD\&E. In BORGES-ANDRADE, J. E.; ABBAD, G. S.; MOURÃO. L. (Org.) Treinamento, desenvolvimento e educação em organizações e trabalho: Fundamentos para a gestão de pessoas. Porto Alegre: Artmed, 2006, p.395-422.

ABBAD, G. Um modelo integrado de avaliação do impacto do treinamento no trabalho IMPACT. Tese (Doutorado em Psicologia) - Instituto de Psicologia, Universidade de Brasília, Brasília, 1999.

ABBAD, G.; LACERDA, E. R. M.; PILATI, R. Medidas de motivação e valor instrumental do treinamento. In: ABBAD, G. S.; MOURÃO, L.; MENESES, P. P. M.; ZERBINI, T.; BORGES-ANDRADE, J. E.; BOAS, R. V. (Org.). Medidas de avaliação em Treinamento, Desenvolvimento e Educação ferramentas para gestão de pessoas. Porto Alegre: Artmed, 2012.

ABBAD, G.; SALLORENZO, L. H. Desenvolvimento e validação de escalas de suporte à transferência de treinamento. Revista de Administração, v. 36, n. 2, p. 33-45, 2001.

ABBAD, G. S.; BORGES-ANDRADE, J.E. Aprendizagem Humana em Organizações de Trabalho. In: ZANELLI, J. C.; BORGES-ANDRADE, J. E.; BASTOS, A. V. B. (Org.). Psicologia, organizações e trabalho no Brasil. Porto Alegre: RS, 2014, p. 244-284.

ALVES FILHO, A. Motivação para o Trabalho: um estudo com os Profissionais de Saúde das Unidades Básicas de Saúde do Município de Natal-RN. Tese (Doutorado em Psicologia) Universidade Federal do Rio Grande do Norte, Natal, 2012.

AZIZ, S. F. A.; AHMAD, S. Stimulating training motivation using the right training characteristics. Industrial and Commercial Training, v. 43, n. 1, p. 53-61, 2011. 
BEIER, M. E.; KANFER, R. Motivation in training and development: A phase perspective. In KOZLOWSKI, S. W. J.; SALAS. E. (Ed.), Learning, training, and development in organizations. New York: Routledge, 2010.

BORGES-ANDRADE J. E. et al. Treinamento, Desenvolvimento e Educação: um modelo para sua gestão. In BORGES, L. O.; MOURÃO, L. O trabalho e as organizações: atuações a partir da Psicologia. Porto Alegre: Artmed, 2013, p. 465-495.

BORGES-ANDRADE, J. E. Avaliação somativa de sistemas instrucionais: integração de três propostas. Tecnologia Instrucional, São Paulo, v. 11, n. 46, p. 29-39, 1982.

BORGES-ANDRADE, J. E. Competência Técnica e Política do profissional de TD\&E. In BORGES ANDRADE, J. E.; ABBAD, G. S.; L. MOURÃO. (Org.). Treinamento, Desenvolvimento e Educação em Organizações e Trabalho: Fundamentos para a Gestão de Pessoas. Porto Alegre - RS, v. 1, p. 255-281, 2006.

BORGES-ANDRADE, J. E. Desenvolvimento de Medidas em Avaliação de Treinamento. Estudos de Psicologia, Natal - RN, v. 7 (Número Especial), p. 31-43, 2002.

BORGES-ANDRADE, J. E.; ABBAD, G. S.; MOURÃO, L. Modelos de avaliação e aplicação em TD\&E. In: G. ABBAD et al. (Org.), Medidas de Avaliação em Treinamento, Desenvolvimento e Educação. Porto Alegre: Artmed, 2012, p. 20-35.

BURKE, L.A.; HUTCHINS, H.M. Training transfer: an integrative literature review. Human Resource Development Review, v. 6, n. 3, p. 263-296, 2007.

CAMPBELL, J. P. Training design for performance improvement. In: CAMPBELL, J. P.; CAMPBELL, R. J. \& Associates (Ed.). Productivity in organizations. San Francisco: Jossey-Bass, 1988, p. 177-215.

CAMPBELL, J. P.; KUNCEL, N. R. Individual and team training. In ANDERSON, N.; ONES, D. S.; SINANGIL, H.K; VISWESVARAN, C. (Ed). Handbook of Industrial, Work and Organizational Psychology. London: Sage Publications, v. 1, p. 278-312, 2001.

CARVALHO-SILVA, A. R. Clima social da organização, motivação e aprendizagem no trabalho. Dissertação (Mestrado em Psicologia Social, do Trabalho e das Organizações) Universidade de Brasília, Brasília, 2008. 
CHIABURU, D. S.; TEKLEAB, A.G. Individual and Contextual Influences on Multiple Dimensions of Training Effectiveness. Journal of European Industrial Training, v. 29, n. 8, p. 604-626, 2005.

CINTRA, R. F.; MUNCK, L.; VIEIRA, S. F. A. A produção intelectual em teoria institucional: uma análise nos principais periódicos brasileiros a partir do método bibliométrico. In: Encontro da Divisão de Estudos Organizacionais da ANPAD, Curitiba, Brasil, 2012.

COELHO JR, F. A. Avaliação de treinamento a distância: suporte à aprendizagem e impacto do treinamento no trabalho. Dissertação (Mestrado em Psicologia) - Instituto de Psicologia, Universidade de Brasília, Brasília, 2004.

COELHO JR, F. A. Suporte à aprendizagem, satisfação no trabalho e desempenho: um estudo multinível. Tese (Doutorado em Psicologia) - Instituto de Psicologia, não publicada. Universidade de Brasília, Brasília, 2009.

COELHO JR, F. A.; ABBAD, G. S.; TODESCHINI, K. Construção e Validação de uma Escala de Suporte à Aprendizagem no Trabalho em uma Instituição Bancária Brasileira. Revista Psicologia Organizações e Trabalho, Brasília, v. 5, n. 2, p. 167-196, 2005.

COLQUITT, J. A.; LEPINE, J. A.; NOE, R. A. Toward an integrative theory of training motivation: A meta-analytic path analysis of 20 years of research. Journal of Applied Psychology, v. 85, p. 678-707, 2000.

COLQUITT, J.; SIMMERING, M. S. Consciousness, goal orientation, and motivation to learn during the learning process: a longitudinal study. Journal of Applied Psychology, v. 83, p. 654-665, 1998.

EBNER, N. C.; FREUND, A. M.; BALTES, P. B. Developmental changes in personal goal orientation from young to late adulthood: From striving for gains to maintenance and prevention of losses. Psychology and Aging, v. 21, p. 664-678, 2006.

FACTEAU, J. D. et al. The influence of general perceptions of the training environment on pretraining motivation and perceived training transfer. Journal of Management, v. 21, p. 125, 1995. 
FIELD, A. Descobrindo a estatística usando o SPSS. 2. ed. Porto Alegre: Artmed, 2009.

FOXON, M. A process approach to the transfer of training. Part 1: The impact of motivation and supervisor support on transfer maintenance. Australian Journal of Educational Technology, v. 9, n. 2, p. 130-143, 1993.

FOXON, M. A process approach to the transfer of training. Part 2: Using action planning to facilitate the transfer of training. Australian Journal of Educational Technology, v. 10, n. 1, p. 1-18, 1994.

FREITAS, I. A. Impacto de treinamento nos desempenhos do indivíduo e do grupo de trabalho: suas relações com crenças sobre o sistema de treinamento e suporte à aprendizagem contínua. Tese (Doutorado em Psicologia) - Instituto de Psicologia, Universidade de Brasília, Brasília, 2005.

GIL, A. C. Métodos e técnicas de pesquisa social. São Paulo: Atlas, 1999.

GREEN, S. B. How many subjects does it take to do a regression analysis? Multivariate Behavioral Research, v. 26, p. 499-510, 1991.

HAIR JR., et al. Análise multivariada de dados. 6.ed. Porto Alegre: Bookman, 2009.

HAMBLIN, A. C. Avaliação e controle do treinamento. São Paulo: McGraw-Hill do Brasil, 1978.

HICKS, W. D.; KLIMOSKI, R. J. Entry into training programs and its effects on training outcomes: a field experiment, Academy of Management Journal, v. 30, n. 3, p. 542-552, 1987.

HORN, J. A rationale and test for the number of factors in factor analysis. Pychometrika, v.30, n. 2, p. 179-185, 1965.

KIRKPATRICK, D. L. Evaluation of training. In: CRAIG, R. L. Training and development handbook. 2 th. New York: McGraw-Hill, 1976. 
LACERDA, E. R. M. Motivação, valor instrumental do treinamento, reação, suporte à transferência e impacto do treinamento no trabalho. Dissertação (Mestrado em Psicologia) - Instituto de Psicologia, Universidade de Brasília, Brasília, 2002.

LACERDA, E. R. M.; ABBAD, G. Impacto do Treinamento no Trabalho: Investigando Variáveis Motivacionais e Organizacionais como suas Preditoras. Revista de Administração Contemporânea. São Paulo, v. 7, n. 4, p. 77-96, out./dez. 2003.

MALVEZZI, S. Do taylorismo ao comportamentalismo 90 anos de desenvolvimento de Recursos Humanos. In: Manual de Treinamento e desenvolvimento, $2^{\mathrm{a}}$ ed. São Paulo: Makron Books, 1994.

MATHIEU, J. E.; MARTINEAU, J. W. Individual and situational influences in training motivation. In: FORD, J. K.; KOZLOWSKI, S.; KRAIGER, K.; SALAS, E.; TEACHOUTH, M. (Ed.). Improving Training Effectiveness in Work Organizations. Mahwah, N.J.: Erlbaum, 1997, p. 193-222.

MATHIEU, J. E.; TANNENBAUM, S. I.; SALAS, E. Influences of individual and situational characteristics on measures of training effectiveness. Academy of Management Journal, v. 35, n. 4, p. 828-47, 1992.

MEIRA, M. Disseminação de informações sobre treinamento: construção e validação de um instrumento de medida. Dissertação (Mestrado em Psicologia) - Instituto de Psicologia, não publicada. Universidade de Brasília, Brasília, 2004.

MENESES, P. P. M. et al. Medidas de características da clientela em avaliação de TD\&E. In: ABBAD, G.; BORGES-ANDRADE, J.; MOURÃO, L. (Org.). Treinamento, desenvolvimento e educação em organizações e trabalho: fundamentos para gestão de pessoas. Porto Alegre: Artmed, 2006.

MENESES, P. P. M.; ABBAD, G. Preditores Individuais e Situacionais de Auto e Heteroavaliação de Impacto do Treinamento no Trabalho. Revista de Administração Contemporânea. Rio de Janeiro, v. 7, p. 185-202, Ed. Especial, 2003. 
MENESES, P. P. M.; ABBAD, G. S. Construção e validação de um instrumento para avaliar auto-eficácia em situações de treinamento, desenvolvimento e educação de pessoas. Psicologia: Reflexão e Crítica, v. 23, p.121-130, 2010.

MENESES, P. P. M.; ZERBINI, T.; ABBAD, G. Manual de treinamento organizacional. Porto Alegre, Artmed, 2010.

MONTE, F. C. D. A política de assentamentos rurais do Incra no contexto do semi-árido nordestino (1995-2002). Dissertação (Mestre em Desenvolvimento, Agricultura e Sociedade) - Instituto de Ciências Humanas e Sociais, Universidade Federal Rural do Rio de Janeiro, Rio de Janeiro, 2006.

MOURÃO, L.; BORGES-ANDRADE, J. E. Avaliação de TD\&E no Nível do Valor Final: possibilidades de mensuração. Anais do $2^{\circ}$ Encontro da Associação Nacional dos Programas de Pós-graduação em Administração (EnANPAD), Brasília, 2005.

MOURÃO, L.; MARINS, J. Quem está motivado para aprender com as ações de treinamentos empresariais? Paidéia, v. 20,p. 187-196, 2010.

NGUYEN, K.; KIM, K. The Impact of Situational Factors on Pre-Training Motivation. Journal of Leadership, v. 10, p. 109-121, 2013.

NOE, R. A.; SCHMITT, N. The influence of trainee attitudes on training effectiveness: test of a model. Personnel Psychology, v. 39, n. 3, p. 497-523, 1986.

NOE, R.A. Trainees' attributes and attitudes: neglected influences on training effectiveness. Academy of Management Review, v. 11, n. 4, p. 736-49, 1986.

PATRICK, J. et al. Being in one's chosen job determines pre-training attitudes and training outcomes. Journal of Occupational and Organizational Psychology, 2011. DOI (Digital Object Identifier): 10.1111/j.2044-8325.2011.02027.x

PÉREZ-RAMOS, J. Motivação no Trabalho: abordagens teóricas. Psicologia USP, São Paulo-SP, v. 1, n. 2, p. 127-140, 1990. 
PETERS, L. H.; O’CONNOR, E. J.; EULBERG, J. R. Situational constraints: Sources, consequences and future considerations. Research in Personnel and Human Resources Management, v. 3, p. 79-11, 1985.

PILATI, R. História e importância de T\&D. In: BORGES-ANDRADE, J.E; ABBAD, G.S.; MOURÃO, L. Treinamento e desenvolvimento e educação em organizações e trabalho: fundamentos para a gestão de pessoas. Porto Alegre: Artmed e Bookman, 2006, p. 159- 176.

PILATI, R. Modelo de efetividade do treinamento no trabalho: aspectos dos treinandos e moderação do tipo de treinamento. Tese (Doutorado em Psicologia) - Instituto de Psicologia, Universidade de Brasília, Brasília, 2004.

RIBEIRO, R. L. Motivação para aprendizagem informal no trabalho: construção de medidas e investigação de modelo teórico. Dissertação (Mestrado em Ciências - Psicologia) Instituto de Psicologia, Universidade de Brasília, Brasília, 2005.

SALAS, E. et al. The science of training and development in organizations: what matters in practice. Psychological Science in the Public Interest, v. 13, n. 2, p. 74-101, 2012.

SALAS, E.; CANNON-BOWERS, J. A. The science of training: A decade of progress. Annual Review of Psychology, v. 52, p. 471-499, 2001.

SAMPIERI, R. H.; COLLADO, C. F.; LUCIO, P. B. Metodología de la investigación. México: McGraw-Hill, 1991.

SILVA, G. G. Necessidades de Treinamento e Motivação para Trabalhar: validação de escalas e testes de relacionamentos. Dissertação (Mestrado em Administração), Universidade de Brasília, Brasília, 2010.

SMITH, R. et al. Exploring the role of goal theory in understanding training motivation. International Journal of Training and Development, v. 12, n. 1, p. 54-72, 2008.

TABACHNICK, B. G.; FIDELL, L. S. Using multivariate statistics. 5th ed. New York: HarperCollins, 2007.

TANENBAUM, S. I.; YUKL, G. Training and development in work organizations. Annual Review of Psychology, v. 43, p. 399-441, 1992. 
THARENOU, P. "Going up? Do traits and informal social processes predict advancing in management?" Academy of Management Journal, v. 44, n. 5, p. 1005-1017, 2001.

TRACEY, J. B. et al. The influence of the individual characteristics and the work environment on varying levels of training outcomes. Human Resource Development Quarterly, v. 12, n. 1, p. 210-214, 2001.

TRIBET, C. W.; RUSH, R. J. Theories of Motivation: a broader perspective. Quality Progress, v. 17, n. 1, p. 38-42, 1984.

VIEIRA, K. M.; DALMORO, M. Dilemas na construção de escala de likert: o número de itens e a disposição influenciam nos resultados? Anais do Encontro Nacional da Associação Nacional de Pós-Graduação e Pesquisa em Administração, Rio de Janeiro, RJ, Brasil, 2008.

VROOM, V. H. Work and Motivation. New York, Wiley, 1964.

WEN, M. L. Y.; LIN, D. Y.C. How supportive Transfer Climate Affects Individual's Motivation to Training Transfer. International Journal of Learning \& Development, v. 4, n. 1, p. 83-97, 2014.

ZANIBONI, S. et al. Training valence, instrumentality, and expectancy scale (T-VIES-it): Factor structure and nomological network in an Italian sample. Journal of Workplace Learning, v. 23, p. 133-151, 2011. 
TERMO DE CONSENTIMENTO PARA PARTICIPAÇÃO EM PESQUISA

Você está sendo convidado (a) a participar de uma pesquisa elaborada pelo Professor Dr. Pedro Meneses do Departamento de Administração da Universidade de Brasília e pelo Mestrando em Administração Bruno Braga sobre suporte à aprendizagem no INCRA-SEDE e Motivação para o treinamento.

Devido ao recorte dessa pesquisa, você somente estará apto (a) a participar se tiver participado de algum treinamento promovido pelo INCRA (interno ou externamente).

Gostaríamos de contar com a sua colaboração no sentido de responder ao questionário objetivo a seguir. $\mathrm{O}$ tempo estimado para responder às questões é entre 5 e 10 minutos.

Lembre-se de que não há respostas certas ou erradas. Todas são corretas desde que correspondam ao que você pensa.

É importante ressaltar que as questões sócio -demográficas ao fim do questionário buscam apenas caracterizar a amostra da pesquisa. Ademais, os dados desta pesquisa são confidenciais e serão utilizados exclusivamente para fins acadêmicos.

A sua participação nesta pesquisa é voluntária. Mas, lembre -se: sua participação é essencial para o sucesso desta pesquisa por estar sendo realizada em seu órgão de trabalho.

Para esclarecer dúvidas e fazer comentários a qualquer momento ou mesmo para conhecer os resultados desta pesquisa, não hesite em entrar em contato conosco: bruno.braga@incra.gov.br ou 61 -4141-9505 ou 61-8242-2193 (TIM).

Agradecemos sua colaboração!

\section{Você aceita participar dessa pesquisa, voluntariamente, após ter sido devidamente} esclarecido? 


\section{ITENS sobre Aspectos Importantes da Vida Profissional do Servidor}

Neste questionário você vai avaliar a importância de determinadas recompensas para sua vida profissional.

Lembre-se de assinalar uma opção em cada afirmativa. Sua opinião è de suma importância.

Para responder selecione A MEDIDA DA ESCALA que melhor expressa sua opinião sobre "QUAL A IMPORTÂNCIA DE CADA

ITEM abaixo para sua vida profissional":

\section{Resolver problemas de trabalho:}
C Extremamente
(c) Muito importante
C Medianamente importante
( Pouco importante
Nada importante importante

2. Melhorar meu desempenho relacionado às tarefas do meu cargo.
C Extremamente
Muito importante
C Medianamente importante
C Pouco importante
C Nada importante importante

\section{Aumentar minhas chances de ascensão na carreira, nessa organização.}

$\checkmark$ Extremamente $\odot$ Muito importante $\odot$ Medianamente importante $\triangle$ Pouco importante $C$ Nada importante importante

\section{Melhorar meu relacionamento com familiares e amigos.}

$\checkmark$ Extremamente $\sim$ Muito importante $\sim$ Medianamente importante $\checkmark$ Pouco importante $\checkmark$ Nada importante importante

\section{Manter-me em meu emprego atual.}

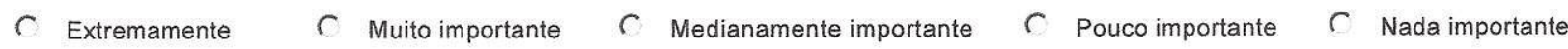
importante

\section{Sentir-me mais valorizado pelo meu grupo de trabalho.}
C Extremamente
C Muito importante
C Medianamente importante
( Pouco importante
C Nada importante importante

\section{Melhorar meu relacionamento com meus colegas de trabalho.}
C Extremamente
C Muito importante
C. Medianamente importante
C Pouco importante
( Nada importante importante

\section{Aumentar minhas chances de conseguir melhores empregos.}
Extremamente
(c) Muito importante
C. Medianamente importante
C Pouco importante
( Nada importante importante

9. Resolver problemas que não se relacionam diretamente com a organização.
C Extremamente
C Muito importante
5 Medianamente importante
(5) Pouco importante
C Nada importante importante

\section{Melhorar o meu currículo.}

$\checkmark$ Extremamente $\sim$ Muito importante $\sim$ Medianamente importante $\sim$ Pouco importante $\odot$ Nada importante importante 
11. Melhorar o relacionamento com meu chefe.

Extremamente $\int$ Muito importante $C$ Medianamente importante $C$ Pouco importante $C$ Nada importante importante

12. Melhorar minha atuação em tarefas não relacionadas ao meu cargo.

$\odot$ Extremamente $\odot$ Muito importante $\odot$ Medianamente importante $\odot$ Pouco importante

C. Nada importante importante

13. Atingir minhas mais altas aspirações profissionais.

Extremamente $\odot$ Muito importante $\odot$ Medianamente importante $\odot$ Pouco importante $\odot$ Nada importante
importante

\section{Aumentar meu salário.}

Extremamente $\sim$ Muito importante $\odot$ Medianamente importante $\sim$ Pouco importante $C$ Nada importante importante 


\section{ITENS sobre Aplicação de Novas Habilidades no Ambiente de Trabalho}

Nesta página você vai avaliar alguns aspectos relacionados à aplicação de novas habilidades adquiridas por meio de treinamentos e outros eventos de aprendizagem.

Para responder reflita sobre o cotidiano de seu ambiente de trabalho e situaçöes que envolvam você, seus colegas e seu(s) superior (es) imediato(s). Escolha A MEDIDA DA ESCALA que melhor expressa sua opiniáo sobre "O QUANTO CADA SITUAÇÄO DESCRITA abaixo ocorre em seu trabalho":

1. Meu chefe/superior imediato valoriza minhas sugestões de mudança.
S Sempre
C Frequentemente
C Algumas vezes
Raramente
C Nunca

2. Meu chefe/superior imediato estimula o uso das minhas novas habilidades e conhecimentos no trabalho.
C Sempre
C Frequentemente
C Algumas vezes
C Raramente
5 Nunca

3. Meu chefe/superior imediato leva em conta minhas ideias quando diferente das dele.
C Sempre
C Frequentemente
C Algumas vezes
(r) Raramente
C Nunca

4. Meu chefe/superior imediato me encoraja a aplicar novas habilidades e conhecimentos.
C Sempre
C Frequentemente
C Algumas vezes
C Raramente
C Nunca

5. Meu chefe/superior imediato me estimula a enfrentar desafios no trabalho.
(5empre
C Frequentemente
Algumas vezes
Raramente
r Nunca

6. Meu chefe/superior imediato assume comigo os riscos de tentar novas formas de realizar o trabalho.
C Sempre
C Frequentemente
( Algumas vezes
Raramente
C Nunca

7. Meu chefe/superior imediato remove dificuldades e obstáculos à aplicação de minhas novas habilidades e conhecimentos no trabalho.
r Sempre
C Frequentemente
C Algumas vezes
C Raramente
C Nunca

8. Meu chefe/superior imediato está disponivel para tirar minhas dúvidas sobre o uso de novas habilidades e conhecimentos no trabalho.
C Sempre
C Frequentemente
Algumas vezes
Raramente
C Nunca

9. Meu chefe/superior imediato me dá liberdade para decidir sobre como desenvolver minhas tarefas.
C Sempre
C Frequentemente
C Algumas vezes
C Raramente
C Nunca

10. Meu chefe/superior imediato estabelece $(m)$ objetivos de trabalho que me encorajam a aplicar novas habilidades e conhecimentos.
C Sempre
C Frequentemente
C Algumas vezes
C Raramente
C Nunca 
11. Meu chefe/superior imediato me elogia quando aplico novas habilidades e conhecimentos.
r Sempre
C Frequentemente
C Algumas vezes
(r) Raramente
C Nunca

12. No meu setor de trabalho novas ideias são valorizadas.
C Sempre
C Frequentemente
C Algumas vezes
C Raramente
C Nunca

13. No meu setor de trabalho há autonomia para questionar as ordens dadas pelo chefe/superior.
Sempre
C Frequentemente
C Algumas vezes
C Raramente
C Nunca

14. No meu setor de trabalho há abertura a críticas quando alguém aplica novas habilidades e conhecimentos.
C Sempre
C Frequentemente
C Algumas vezes
r Raramente
C Nunca

15. No meu setor de trabalho há tolerância a erros quando se tenta aplicar novas habilidades e conhecimentos.
( Sempre
C Frequentemente
C Algumas vezes
(C) Raramente
C Nunca

16. No meu setor de trabalho há autonomia para organizar o trabalho.
r Sempre
C Frequentemente
(C) Algumas vezes
r Raramente
r Nunca

17. No meu setor de trabalho há autonomia para agir sem consultar o chefe/superior.
S Sempre
C Frequentemente
C Algumas vezes
(5) Raramente
r Nunca 
continuação... você já está quase concluindo a pesquisa. Veja a instrução abaixo.

Escolha A MEDIDA DA ESCALA que melhor expressa sua opinião sobre "O QUANTO CADA SITUAÇÃO DESCRITA abaixo ocorre em seu trabalho":

1. No meu setor de trabalho há aceitação dos riscos associados à aplicação de novas habilidades e conhecimentos.
( Sempre
5 Frequentemente
Algumas vezes
Raramente
C Nunca

2. No meu setor de trabalho as tentativas de aplicação de novas habilidades e conhecimentos são elogiadas.
( Sempre
F Frequentemente
C. Algumas vezes
( Raramente
r Nunca

3. No meu setor de trabalho há incentivo à busca por novas aprendizagens.
( Sempre
C Frequentemente
C Algumas vezes
C Raramente
C Nunca

4. No meu setor de trabalho cada membro é incentivado a expor o que pensa.
( Sempre
Frequentemente
Algumas vezes
C Raramente
C Nunca

5. No meu setor de trabalho há compartilhamento de informações sobre novas habilidades e conhecimentos.
( Sempre
$\checkmark$ Frequentemente
C Algumas vezes
$\checkmark$ Raramente
r Nunca

6. No meu setor de trabalho há respeito mútuo.
(r) Sempre
5 Frequentemente
C Algumas vezes
C Raramente
C Nunca

7. No meu setor de trabalho as tarefas facilitam a aplicação de novas habilidades e conhecimentos.
(c) Sempre
F Frequentemente
C Algumas vezes
r Raramente
C Nunca

8. No meu setor de trabalho há tempo destinado para a busca de novas formas de executar o trabalho.
r Sempre
C Frequentemente
C Algumas vezes
Raramente
C Nunca

9. Meus colegas/pares de trabalho me estimulam a buscar novas habilidades e conhecimentos voltados ao trabalho.
S Sempre
C Frequentemente
Algumas vezes
( Raramente
C Nunca

10. Meus colegas/pares de trabalho me incentivam a propor novas idelas para a execução de tarefas.
C Sempre
Frequentemente
C Algumas vezes
Raramente
N Nunca 
11. Meus colegas/pares de trabalho apoiam minhas tentativas de buscar novas aprendizagens no trabalho.
(5) Sempre
C Frequentemente
(C) Algumas vezes
C Raramente
C Nunca

12. Meus colegas/pares de trabalho me elogiam quando aplico minhas novas habilidades e conhecimentos.
S Sempre
C Frequentemente
Algumas vezes
C Raramente
r Nunca

13. Meus colegas/pares de trabalho sentem -se seguros quando aplico novas habilidades e conhecimentos no trabalho.
( Sempre
C Frequentemente
Algumas vezes
C Raramente
( Nunca

14. Meus colegas/pares de trabalho me dão orientações quando tenho difficuldades para aplicar novas habilidades e conhecimentos.
(5) Sempre
C Frequentemente
Algumas vezes
C Raramente
C Nunca

15. No meu setor de trabalho a distribuição das tarefas facilita a participação em treinamentos.
C Sempre
$\checkmark$ Frequentemente
Algumas vezes
( Raramente
( Nunca

16. Meu chefe/superior imediato me incentiva a propor mudanças em função do que aprendi em treinamentos.
C Sempre
Frequentemente
C. Algumas vezes
C Raramente
C Nunca

17. Meus colegas/pares de trabalho apoiam as tentativas que faço de utilizar no trabalho novas habilidades que aprendi em treinamentos.
C Sempre
C Frequentemente
C. Algumas vezes
r Raramente
( Nunca

18. Antes de passar para a última página responda a seguinte questão" " você ocupa cargo de chefia/supervisão (e possui subordinados)?
r sim
C Não 


\section{ÚLTIMA PÁGINA. Você está prestes a finalizar a pesquisa.}

\section{ITENS sobre A UTILIDADE DOS TREINAMENTOS do INCRA}

Lembre-se de assinalar uma opção em cada afirmativa. Sua opiniäo é de suma importância.

Para responder selecione A MEDIDA DA ESCALA que melhor expressa sua opinião sobre "QUAL A UTILIDADE DOS

TREINAMENTOS que você já realizou no INCRA para o alcance de cada item abaixo":

1. Resolver problemas de trabalho.
Completamente útil $\odot$ Muito útil
Nem muito, nem
C Pouco útil
C Nada útil pouco útil

2. Melhorar meu desempenho relacionado às tarefas do meu cargo.
Completamente útil $\bigcirc$ Muito útil
C Nem muito, nem
C Pouco útil
Nada útil pouco útil

3. Aumentar minhas chances de ascensão na carreira, nessa organização.
Completamente útil $\bigcirc$ Muito útil
C Nem muito, nem pouco útil
( Pouco útil
Sada útil

\section{Melhorar meu relacionamento com familiares e amigos.}
Completamente útil $\bigcirc$ Muito útil
C Nem muito, nem
C Pouco útil
Nada útil pouco útil

5. Manter-me em meu emprego atual.

Completamente útil $\odot$ Muito útil
C Nem muito, nem pouco útil

C Nada úti

\section{Sentir-me mais valorizado pelo meu grupo de trabalho.}

Completamente útil $\odot$ Muito útil
C Nem muito, nem pouco útil

Nada útil

7. Melhorar meu relacionamento com meus colegas de trabalho.
Completamente útil $C$ Muito útil
C. Nem muito, nem
C Pouco útil
C Nada útil pouco útil

8. Aumentar minhas chances de conseguir melhores empregos.
Completamente útil $\odot$ Muito útil
Nem muito, nem
Pouco útil
Nada útil pouco útil

9. Resolver problemas que não se relacionam diretamente com a organização.
Completamente útil $C$ Muito útil
Nem muito, nem
Pouco útil
C Nada útil pouco útil 
10. Melhorar o meu currículo.
Completamente útil $\bigcirc$ Muito útil
Nem muito, nem
C Pouco útil
C Nada útil pouco útil

11. Melhorar o relacionamento com meu chefe.
Completamente útil $\bigcirc$ Muito útil
Nem muito, nem
C Pouco útil
Nada útil pouco útil

12. Melhorar minha atuação em tarefas não relacionadas ao meu cargo.
Completamente útil $\subset$ Muito útil
() Nem muito, nem
( Pouco útil
Nada útil pouco útil

\section{Atingir minhas mais altas aspirações profissionais.}

Completamente útil $\odot$ Muito útil

\section{Aumentar meu salário.}

$\checkmark$ Completamente útil $C$ Muito útil

$\odot$ Nem muito, nem $\quad \odot$ Pouco útil $\quad \odot$ Nada útil
pouco útil

\section{Responda a seguinte questão:}

- Pensando nos treinamentos do INCRA que você já participou, qual é sua expectativa de alcançar os valores acima descritos graças às habilidades que você desenvolveu nesses treinamentos?

$\begin{array}{ccccc}\sim \text { Extrema } & \sim \text { Muita Expectativa } & \sim \text { Nem muita, nem } & \sim \text { Pouca Expectativa } & \sim \text { Nenhuma } \\ \text { Expectativa } & \text { pouca Expectativa } & \text { Expectativa }\end{array}$

Por fim, responda os dados profissionais e sociodemográficos abaixo e CLIQUE EM PRÓXIMO para receber nossos agradecimentos!

16. Qual o último grau de escolaridade que você concluiu:

C Ensino Médio

Ensino Superior

C Pós-Graduação lato sensu (MBA, especialização)

C Pós-Graduação stricto sensu (Mestrado)

C Pós-Graduação stricto sensu (Doutorado)

17. Em qual unidade você trabalha no INCRA?

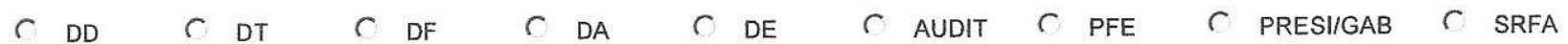

18. Tempo de Serviço (no INCRA):

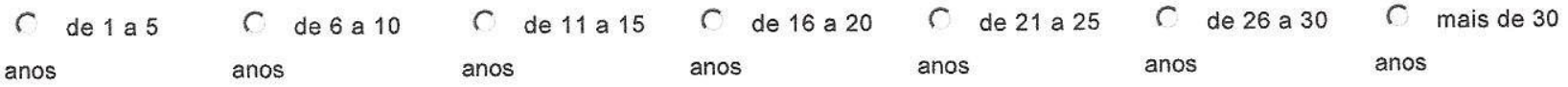

\section{Sexo:}

( Masculino 
100

20. Sua idade:

até 20 anos

C 21 a 30 anos $C \quad 31$ a 40 anos 41 a 50 anos

C 51 a 60 anos

C Acima de 60

anos 


\author{
MINISTÉRIO DO DESENVOLVIMENTO AGRARIO - MDA \\ INSTITUTO NACIONAL DE COLONIZAÇĀO E REFORMA AGRÁRIA - INCRA \\ DIRETORIA DE GESTÃO ADMINISTRATIVA = DA \\ COORDENAÇÃO-GERAL DE GESTÃO DE PESSOAS - DAH \\ SBN - Palácio do Desenvolvimento $17^{\circ}$ - sala 1703 - CEP 70057.900 \\ Fone $3411-7331$
}

AUTORIZAÇÃO PARA REALIZAÇÃO DE PESQUISA

Autorizo o servidor BRUNO ALEXANDRE BRAGA, matrícula SIAPE 15495663, a desenvolver pesquisa no âmbito do Instituto Nacional de Colonizaçăo e Reforma Agrária - INCRA, para obtenção do título de mestre em Administraçăo. Ficam autorizadas a coleta e a publicação de informaçães de caráter público da autarquia e também a aplicação dos questionários de pesquisas junto aos servidores (online e presencial), tendo em vista que fui informada pelo Professor da Universidade de Brasilia, Dr. Pedro P. M. Meneses que a pesquisa será de caráter voluntárío e que não haverá publicação de nenhum dado que comprometa o sigilo da participacão dos integrantes dessa autarquia como nome, endereço e outras informações pessoais.

Brasília, 15 de setembro de 2014.

Eva Rara de Souza Sardinina

Coordenadora-Geral de Gestão de Pessoas 


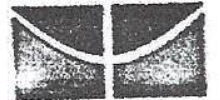 \\ Universidade de Brastia - UnB \\ Faculdade de Economia, Administraçalo, Contabilidade c Ciencia da informaflio e \\ Documentaç
}

Em IS de serembro de 2014

\begin{abstract}
A sua Senhoria a Senhora
Eva Maria de Soexen Sardinha

Coordexadora Geral de Gestìo de Pessoas

Instituto Nacional de Colonizacaio e Reforma Agrária

Editicio Palácio do Desenvolvimenta, SBN Qd 01 Bloco D, Térreo

CEP: 70.057-900-Brasilia-DF
\end{abstract}

\section{Assunto: Coleta de Dades de Pesquisa ma írê de RH}

\section{Sentors Coondenadora Geral,}

1.

Eu, Pedro P. M. Meneses, Professor Doutcr do Programa de Pós-Graduaçio em Administraça da Universidade de Brasilia, e Bruno Alexandre Braga, aluno regularmente matriculado no Curso de Mestrado em Administraçào da Universidade de Brasilia e servidor do

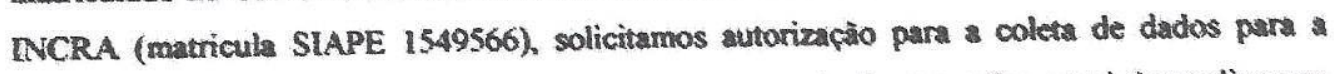
pesquisa intitulada "Motivacão para o Treinamento e sua relacào com o Suporte à Aprendizagem e as Caracteristicas Sóciodemograficas", conforme Introducảo do projeto de pesquisa anevo, aprovado em defesa de qualificaça.o. Os dados obtidos de forma online e presencial nesta pesquiss serào utilizados para a produçào de Dissertaçăo de Mestrado, necessaria para a obtença do titulo de Mestre em Administracào. Assumimos a total responsabilidade de nào publicar qualquer dado que comprometa o sigilo da participação dos integrantes de vosca

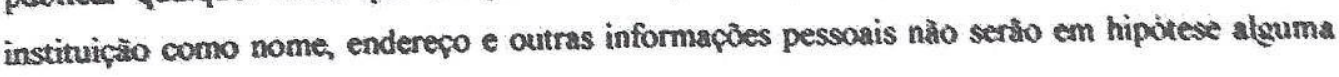
publicados.

2.

Vale salientar que a participaçăo dos servidores nesca pesquisa serai voluntàrì e a qualquer momento vossa senhoria poderá solicitar esclarecimento sobre o desenvolvimento do projeto de pesquisa em questão.

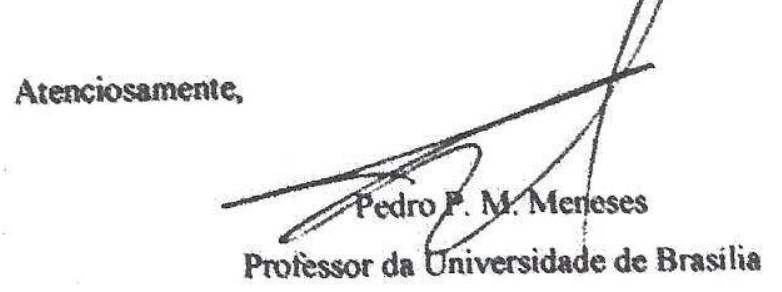

